\title{
Ion-Surface Collisions in Mass Spectrometry: Where Analytical Chemistry Meets Surface Science
}

Julia Laskin

Physical Sciences Division, Pacific Northwest National Laboratory, Richland, WA, 99354

Author for correspondence:

Julia Laskin (Julia.Laskin@pnnl.gov)

Physical Sciences Division

Pacific Northwest National Laboratory

PO Box 999, K8-88

Richland, WA 99352 USA

Keywords: Surface-induced dissociation, ion soft landing, self-assembled monolayer surfaces 


\begin{abstract}
This article presents a personal perspective regarding the development of key concepts in understanding hyperthermal collisions of polyatomic ions with surfaces as a unique tool for mass spectrometry applications. In particular, this article provides a historic overview of studies focused on understanding the phenomena underlying surface-induced dissociation (SID) and mass-selected deposition of complex ions on surfaces. Fast energy transfer in ion-surface collisions makes SID especially advantageous for structural characterization of large complex molecules, such as peptides, proteins, and protein complexes. Soft, dissociative, and reactive landing of mass-selected ions provide the basis for preparatory mass spectrometry. These techniques enable precisely controlled deposition of ions on surfaces for a variety of applications. This perspective article shows how basic concepts developed in the 1920s and 1970s have evolved to advance promising mass-spectrometry-based applications.
\end{abstract}

\title{
Introduction
}

Studies of ion-surface collisions date back to J.J. Thomson's experiments in the early 1900s.[1] These experiments demonstrated that when beams of positive ions ("positive rays") strike a photographic plate, they remove the material from the plate through a process we now call "sputtering" and leave clear marks, providing a "permanent record of the position of the rays".[1] Furthermore, ions of different mass-to-charge ratio $(\mathrm{m} / \mathrm{z})$ could be separated and identified by deflecting the ion beam with electric and magnetic fields and examining the position of the marks on a photographic plate. These experiments led to the discovery of atomic isotopes and underpinned the development of mass spectrometry as an analytical tool. Since these initial discoveries, collisions of atomic ions with surfaces have been used extensively for surface modification and analysis. This article focuses on collisions of polyatomic ions with surfaces at hyperthermal energies $(<100 \mathrm{eV})$ that have been systematically studied since the late 1970s. In 1977, Cooks and co-workers introduced ion soft landing for controlled preparation of substrates using beams of mass-selected ions.[2] In 1985, the same group described the first experimental apparatus using surface-induced dissociation (SID) for tandem mass spectrometry (MS/MS) experiments.[3] Subsequent work by Wysocki and co-workers established SID as a 
powerful tool for mechanistic studies of peptide fragmentation,[4] providing the foundation for the mobile proton model.[5]

Physical and chemical processes accompanying ion-surface collisions are determined by the incidence angle, kinetic energy, and structure of the projectile ion, as well as surface properties. Low-energy collisions $(<20 \mathrm{eV})$ typically result in ion scattering, charge transfer, or soft landing, where the projectile ion is trapped on the surface.[6-11] At higher kinetic energies (20 $\square 60 \mathrm{eV}$ ), SID resulting from vibrational excitation of the scattered polyatomic ions becomes a dominant process. $[4,12,13]$ Furthermore, ion reactive landing, which results in covalent attachment of intact ions or their fragments to surfaces, and reactive scattering, where the projectile ion picks up a chemical group from the surface prior to scattering, are commonly observed in this kinetic energy range. $[14,15]$ Higher-energy collisions $(>100 \mathrm{eV})$ result in ion shattering generating a large number of fragment ions. [16-21] Depending on the properties of the projectile ion, chemical sputtering of molecules from surfaces may occur both at low and relatively high collision energies, $[6,14,22]$ while physical sputtering and implantation are dominant processes at collision energies exceeding $1 \mathrm{keV} .[23-26]$

This perspective article discusses important steps in the development of SID as a powerful tool for structural characterization of complex molecules and of mass spectrometry as a preparatory tool based on soft and reactive landing of mass-selected ions. Secondary ion mass spectrometry (SIMS) is a subject of another perspective article in this series and will not be discussed here. This article will provide a brief historical overview of the early work that established the foundation for studying ion-surface collisions followed by a brief discussion of the relevant phenomena and several examples from more recent studies that demonstrate the power of these techniques. The material presented here is by no means exhaustive and covers only a limited range of topics. For comprehensive coverage of the research field, readers are referred to excellent reviews on these and other topics.[4, 6-12, 15, 27-29]

\section{Early Studies of Ion Scattering and Accommodation on Surfaces}

Early studies primarily focused on collisions of atomic ions with surfaces. Figure 1a shows a diagram of one of the first instruments for studying ion scattering from surfaces.[30] In this system, atomic ions were produced in a source (O) housed inside a nickel drum (D). Ions produced in the source were accelerated through a $0.8-\mathrm{mm}$ aperture in D toward a target $(\mathrm{T})$. A 
nickel box $(\mathrm{F})$ enclosed in a shield $(\mathrm{S})$ pierced with a 1.2-mm aperture was used as a detector. The collector could be moved around the target (along the dashed line) to examine the angular distribution of the scattered ions. This instrument was used to study scattering of atomic ions off a platinum foil.[30] It was found that scattered ion intensity depends on the incidence angle, the ion's kinetic energy, and surface temperature. A sharp maximum of the scattered ion intensity was observed around $40 \mathrm{eV}$ collision energy, $66^{\circ}$ incidence angle, and $75^{\circ}$ reflection angle (Figure 1b), while a very low scattered signal was observed along the surface normal. The nonspecular scattering, reported for the first time in that study, will be discussed in more detail later in this article.

Figure 2 shows a schematic drawing of the first soft landing apparatus.[31] In this instrument, ions were produced via a low-voltage arc between the hot tungsten filament $(\mathrm{F})$ and anode (A). The ions were collected using a metal sphere collector (C) connected to a potentiometer. To monitor temperature changes during ion deposition, a thermocouple was embedded into the sphere. A molybdenum collector was used in experiments with argon and neon, while a platinum sphere was used for detecting helium. Positive and negative currents were recorded with the temperature change of the collector as a function of time. Accommodation coefficients (roughly equivalent to soft-landing efficiencies) were derived from the ratio of measured heating of the collector to expected heating (assuming that all of the kinetic energy of the ions is dissipated in the form of heat during collision). The following accommodation coefficients were derived from the data obtained for $21-51 \mathrm{eV}$ collisions: 0.75 for argon, 0.65 for neon, and 0.35 for helium.[31] It is remarkable that such a simple apparatus enabled a reasonably accurate measurement of soft landing efficiency.

Figure 3 shows a schematic drawing of one of the first SIMS instruments used in a study, in which negative ions emitted upon the bombardment of surfaces with $\mathrm{Li}^{+}$cations were identified using a magnetic analyzer.[32] Negative ions emitted from the target (T) were accelerated toward the magnetic analyzer by a positive potential applied between the filament $(F)$ and target. Negative $\mathrm{F}^{-}, \mathrm{Cl}^{-}, \mathrm{S}^{-}$, and $\mathrm{O}^{-}$ions were identified following the bombardment of $\mathrm{NaF}$, $\mathrm{NaCl}, \mathrm{PbS}$, and $\mathrm{CaO}$ with $500 \mathrm{~V}$ lithium ions, respectively. Abundant $\mathrm{H}^{-}, \mathrm{H}_{2}^{-}, \mathrm{OH}^{-}$, and $\mathrm{Cl}^{-}$were emitted from clean metal targets. $\mathrm{H}^{-}, \mathrm{H}_{2}{ }^{-}, \mathrm{OH}^{-}$were attributed to the dissociative desorption of the adsorbed water molecules, while $\mathrm{Cl}^{-}$ions originated from impurities. The negative ion 
intensity was found to diminish rapidly with a decrease in the kinetic energy of $\mathrm{Li}^{+}$primary ions. However, some sputtered ions were observed even in $50 \mathrm{eV}$ collisions.[32]

\section{Anomalous Metastable Peaks}

In the 1950s, improvements in vacuum technology revived interest in atomic ion-surface bombardment as a means of surface analysis using SIMS.[33] However, studies of polyatomic ion collisions with surfaces did not initiate until the late 1970s. Interest in this research area was triggered by the serendipitous discovery of anomalous metastable peaks in double-focusing sector instruments first reported by Beynon and co-workers in 1968.[34] The double-focusing sector instrument is composed of both a magnetic and an electric sector connected by a field-free region. Metastable ions undergoing unimolecular or collision-induced dissociation (CID) in the field-free region have been used extensively for structural characterization of organic molecules using MS.[35] In double-focusing instruments, metastable ions are observed as fairly broad features; the position of the metastable peak can be calculated based on the $\mathrm{m} / \mathrm{z}$ values of the precursor and the fragment ion. Anomalous metastable peaks were observed at $\mathrm{m} / \mathrm{z}$ values that did not correspond to the calculated peak positions.[34, 36, 37] In fact, the positions of the anomalous peaks indicated that corresponding fragment ions had a higher velocity than predicted by the conservation of momentum. A systematic study by Beynon, Ast, and Cooks demonstrated that anomalous metastable peaks originate from dissociation of precursor ions induced by glancing-incidence collisions with the magnetic sector's upper and lower walls.[37] Subsequently, SID was examined by incorporating a 5-cm long, stainless-steel tube between the ionization source and magnetic sector.[38] Fragment ions of comparable intensity were observed using SID and high-energy CID of small ions. In addition, charge inversion was observed for collisions of $\mathrm{Br}^{+}$with surfaces, resulting in the formation of $\mathrm{Br}^{-}$through a two-electron process.[38]

\section{Instrumentation}

These initial studies led to development of specialized instrumentation for studying ionsurface collisions. Detailed description of these instruments is outside this article's current scope. Instead, for a detailed summary of the relevant instrumentation, readers should refer to a number of excellent reviews.[6, 7, 11, 29] Ion soft landing instruments comprise an ionization source, a 
mass filter, and a deposition target. Ions of organic, organometallic, and biological molecules typically are produced using electron impact (EI)[2, 39, 40] or electrospray ionization (ESI)[4143] while laser desorption ionization and magnetron sputtering have been used for generating cluster ions and other species that cannot be produced in solution.[23, 44-47] Although many mass filtering devices have been used in soft landing experiments, $[6,7,11,29]$ quadrupole mass filters are by far the most popular systems for the deposition of ions produced in continuous ionization sources such as ESI, EI, or magnetron sputtering. Many soft landing instruments are equipped with in situ surface characterization capabilities including SIMS, [42, 48, 49] surface enhanced Raman spectroscopy (SERS),[50, 51] infrared reflection-absorption spectroscopy (IRRAS),[52, 53] temperature-programmed desorption (TPD),[40, 53, 54] and scanning tunneling microscopy (STM),[55-57] X-ray and ultraviolet photoelectron spectroscopy (XPS and UPS),[58] and thermal desorption spectroscopy (TDS).[58] Ex situ surface analysis has been performed using transmission electron microscopy (TEM), [59, 60] atomic force microscopy (AFM),[40] and other techniques. These techniques provide information about the charge state, structure, reactivity, and surface binding energy of the deposited species.

SID experiments involve mass selection of the precursor ion prior to collision and mass analysis of the resulting fragments. The first experimental apparatus specially designed for SID experiments was a hybrid $\mathrm{BQ}(\mathrm{B}=$ magnetic sector; $\mathrm{Q}=$ quadrupole) system, where ions selected in a magnetic sector passed through a deceleration lens and were directed toward a surface at $25^{\circ}$.[3] Scattered ions were collected at a specular angle and transferred through an electrostatic analyzer (E) and a quadrupole mass analyzer (Q) to a detector.[3] Tandem quadrupole instruments (QQ-SID), in which a surface is located between two quadrupole mass analyzers positioned at $90^{\circ}$ relative to each other, have been used extensively in SID experiments.[61-63] Several in-line devices also have been developed for implementing SID on commercial mass spectrometers,[64-66] including modification of a quadrupole time-of-flight (Q-TOF) instrument to study SID of proteins and protein complexes.[65] In addition, SID has been examined using ion trap,[67] hybrid sector,[68] TOF,[69-73] and Fourier transform ion cyclotron resonance (FTICR) instruments.[74-78] FT-ICR SID experiments are performed by placing a surface at the rear trapping plate of the ICR cell and bombarding it with ions generated in an external ionization source along the surface normal.[75] The kinetic energy of the ions is controlled by a potential applied to the ICR cell. Because of the presence of a strong magnetic field in the ion beam 
acceleration/deceleration region, ion trajectories are independent of the projectile ion kinetic energy. The high ion collection efficiency in the strong magnetic field, which efficiently confines low-energy ions scattered off surfaces independent of the scattering angle, and high-resolution mass analysis of the fragments make this system particularly attractive for studying SID of large ions. SID also has been coupled with ion mobility separation for structural characterization of conformationally selected complex molecules and non-covalent complexes.[71, 79-81] Several instruments have been developed for studying the dynamics of ion scattering from surfaces. In these instruments, the detector is rotated with respect to the collision target, and the scattered ion beam is examined at different scattering angles as a function of the ion's kinetic energy.[82-86]

\section{The Properties of Surfaces Matter}

To avoid charge buildup on the surface, ion-surface collision experiments use conductive and semi-conductive targets. Initial SID experiments using clean metal targets (e.g., gold, silver, or stainless steel) indicated that at typical pressures in the target region of $\sim 10^{-7}-10^{-6}$ Torr, metal surfaces are covered with adventitious hydrocarbons originating from pump oil.[13] Abundant products of ion-surface reactions and chemical sputtering of hydrocarbons observed in SID are detrimental to its performance in analytical applications. Furthermore, the neutralization efficiency of polyatomic ions in collisions with hydrocarbon-coated metal surfaces is fairly high. In contrast, much lower neutralization efficiency and significantly lower yields of chemical sputtering and ion-surface reaction products were observed in SID experiments by Cooks, Wysocki, and co-workers involving self-assembled monolayers (SAM) of alkylthiols and fluorinated thiols on gold.[87, 88] Since these initial studies, SAMs became popular targets for both SID and soft landing experiments.[14] SAMs of alkylthiols are densely packed, 1-nmthick organic layers, making them robust and reproducible targets that remain stable in the vacuum system of a mass spectrometer for several months. A large variety of thiols terminated with different functional groups now are commercially available, which facilitates tailoring surface properties for a specific application. Later in this article, several examples of ion collisions with SAMs terminated with different functional groups will be presented.

Other surfaces used in ion-surface collision studies include highly oriented pyrolytic graphite (HOPG)[40] and thin layers of insulating materials (e.g., metal oxides, metal salts, and diamond) on metal substrates.[46, 51, 89-91] Physical and chemical properties of the surface 
have a significant effect on the energy transfer in collision, neutralization, and scattering dynamics of importance to SID experiments.[20, 89, 92] In soft and reactive landing experiments, the surface properties determine trapping/reaction efficiency, as well as binding energy, charge retention, and, ultimately, the structure and reactivity of ions trapped on the surface.

\section{Energy Transfer and Dynamics of Ion-Surface Collisions}

In SID experiments, the internal excitation of the ion occurs on a timescale of picoseconds[93] and is controlled by varying its initial kinetic energy, which is readily achieved by applying a potential to the surface. Some key findings that transpired from numerous experimental and theoretical studies focused on understanding energy transfer and dynamics of ion-surface collisions can be summarized as follows:

1) Ions are scattered closer to the surface than predicted based on specular scattering. $[85,92$, 94-98] The scattering angle measured with respect to surface normal (Figure 1b) decreases with an increase in the kinetic energy of the projectile ion. In other words, at low collision energies, ions are scattered a little closer to the surface than at higher collision energies. This finding was attributed to efficient damping of the velocity component perpendicular to the surface and conservation of the parallel velocity component during collision.[92]

2) Ion survival probability is much higher for even-electron than for odd-electron ions.[39, 99] For example, $12 \%$ and $0.3 \%$ survival probability was reported for $60^{\circ}$ collisions of $\mathrm{CD}_{5}{ }^{+}$and $\mathrm{CD}_{4}^{+\bullet}$, respectively, with a fluorinated self-assembled monolayer (FSAM) surface.[92] In addition, ion neutralization on SAMs is affected by the terminal group's properties. For example, a systematic study of small radical cation collisions with $\mathrm{CF}_{3^{-}}, \mathrm{CF}_{3} \mathrm{CF}_{2^{-}}$, and $\mathrm{C}_{10} \mathrm{~F}_{21}$-terminated SAMs indicated that regardless of the length of the fluoroalkyl terminal chain, the presence of the $\mathrm{CF}_{3}$ terminal group significantly suppresses ion neutralization in collision.[100]

3) The incident angle strongly affects the kinetic energy distribution of inelastically scattered ions.[92, 94, 95, 101] Specifically, the most probable kinetic energy shifts toward lower values, and the distribution width decreases when the collision angle approaches surface normal. Low kinetic energies of the scattered ions in normal-incidence SID enable efficient 
trapping of ions in FT-ICR SID experiments.[78] However, efficient damping of the kinetic energy also facilitates ion soft landing, which competes with scattering.

4) Ion-surface collisions result in deposition of quasi-thermal distributions of internal energies.[102] The solid lines in Figure 4 show internal energy distributions of protonated dialanine following collisions with an FSAM surface at different kinetic energies. These distributions are closely approximated by Boltzmann distributions of varying temperatures (shown as dashed lines in the figure). Efficient thermalization of ions' vibrational degrees of freedom also has been observed in classical trajectory simulations by Hase and coworkers[103] and in angular-resolved experiments by Hermann and co-workers.[92]

\section{Energy Partitioning in Ion-Surface Collisions}

Energy partitioning has been examined both experimentally and theoretically.[20, 85, 9294, 101, 104-107] A fraction of the initial kinetic energy of the projectile ion is partitioned into the surface, while the remaining energy is distributed between the translational and internal modes of the scattered ion. Figure 5 depicts a summary of classical trajectory calculations of energy partitioning in collisions of protonated octaglycine, $\left[\mathrm{Gly}_{8}+\mathrm{H}\right]^{+}$, with a SAM of alkylthiol on gold (HSAM) surface at $0^{\circ}$ and $45^{\circ}$.[108] The percentage of energy transfer into the internal excitation of the ion, $\mathrm{E}_{\mathrm{int}}$, is the same for both incidence angles and independent of collision energy. The percentage of energy transfer to the surface, $\mathrm{E}_{\text {surf }}$, increases with collision energy and is $\sim 1.4$ times higher for $0^{\circ}$ compared to $45^{\circ}$ collisions. In contrast, the fraction of the ion's initial kinetic energy converted into the translation of the scattered ions, $E_{t r}$, decreases with an increase in collision energy and is greater for $45^{\circ}$ collisions. Similar results were obtained for smaller glycine- and alanine-containing peptides colliding with HSAM and FSAM surfaces.[103, 106, 109] These findings are consistent with the experimental data reported by Herman and coworkers for collisions of small projectile ions with SAM surfaces.[92, 101]

Classical trajectory calculations of peptide ion collisions with SAM surfaces also indicate that the percentage of energy transfer into the internal excitation of the ion is rather insensitive to both the projectile ion's size and composition. Specifically, similar average values were obtained for $\mathrm{Cr}(\mathrm{CO})_{6}{ }^{+},[20]\left[\mathrm{Ala}_{2}+\mathrm{H}\right]^{+},[109]$ and $\left[\mathrm{Gly}_{\mathrm{n}}+\mathrm{H}\right]^{+}$ions $(\mathrm{n}=1-5,8)[103]$ colliding with HSAM surfaces. Furthermore, similar average energy transfer efficiencies were derived from the experimental SID data obtained for peptides differing in size and complexity.[4, 102, 110, 111] 
Trajectory simulations indicate that $\sim 80 \%$ of the internal excitation is absorbed by the peptide torsional modes,[103] which could rationalize the lack of dependence on the projectile ion's size and composition for the average internal energy transfer in collisions.

\section{Effect of the Surface on Energy Transfer in Collision}

Both the average energy transfer and width of the internal energy distribution deposited in ion-surface collision are affected by the surface properties. For example, the percentage of translational-to-vibrational $(\mathrm{T} \rightarrow \mathrm{V})$ energy transfer is in the range of $18-28 \%$ for FSAMs and 812\% for HSAMs.[13, 89, 92, 103, 112] Similar internal energy distributions were reported for collisions of small ions with HSAM, carboxylic acid-terminated SAM (COOH-SAM), HOPG, and hydrocarbon-covered metal surfaces.[92] The average $\mathrm{T} \rightarrow \mathrm{V}$ energy transfer is affected mainly by the surface's "effective mass" given by the mass of the chemical moiety representing an immediate collision partner in ion-surface collisions.[89, 92] Comparison of the energy transfer in collisions of peptides with relatively soft SAMs and relatively stiff LiF and diamond surfaces demonstrated that surface stiffness has a major effect on the width of the internal energy distribution.[89] Specifically, substantially broader internal energy distributions are deposited by collisions with stiff surfaces. These experimental observations are in excellent agreement with the results of classical trajectory simulations by Hase and co-workers.[20, 103] The simulations indicate that differences in the $\mathrm{T} \rightarrow \mathrm{V}$ transfer efficiency originate from different scattering dynamics of ions colliding with stiff and soft surfaces. For example, less than $10 \%$ of the precursor ion's initial kinetic energy is transferred to the surface, and more than $70 \%$ is converted into the translational energy of scattered ions in collisions with stiff surfaces compared to $\sim 60 \%$ and $\sim 30 \%$, respectively, for collisions with soft HSAM surfaces.[20, 103] Although, as discussed earlier, the average $\mathrm{T} \rightarrow \mathrm{V}$ transfer efficiency in collisions with SAM surfaces is independent of the incidence angle, the average energy deposition into the precursor ion's internal modes in collisions with a crystalline diamond (111) surface decreases as the incidence angle increases from $0^{\circ}$ to $45^{\circ}$.[106] These studies indicate that the internal energy distribution deposited into the projectile ion is controlled predominately by the surface properties.

\section{The Shattering Transition}


Although SID is commonly described as a process, in which rapid excitation of the ion is followed by slow unimolecular dissociation in the gas phase, several experimental and theoretical studies demonstrated that at relatively high kinetic energies of the projectile ions, ionsurface collisions may result in a non-statistical dissociation.[16-21, 93, 113, 114] Classical trajectory calculations distinguish the statistical fragmentation of the precursor ion from shattering by comparing the ion's lifetime with the lifetime predicted by the Rice-RamspergerKassel-Marcus (RRKM) expression. The lifetime of $\mathrm{Cr}(\mathrm{CO})_{6}{ }^{+}$ions excited by collisions with HSAM has been shown to be consistent with the RRKM lifetime. Meanwhile, the average lifetime of $\mathrm{Cr}(\mathrm{CO})_{6}{ }^{+}$ions following collisions with a diamond surface is, at least, an order of magnitude lower than the RRKM lifetime and rather insensitive to the ion's internal energy.[20] Shattering opens up new fragmentation pathways not accessible through slow unimolecular fragmentation.[21, 114] Classical trajectory simulations indicate that for specific orientations of the precursor ion relative to the surface at the time of collision, the collision may drive the ion to a transition state structure with a fairly high threshold that cannot compete with lower-energy channels in the unimolecular dissociation process.[103] Simulations of cluster-surface collisions indicate that shattering fragmentation is entropy driven, and the fragment distribution primarily is determined by the product ions' thermochemical stability.[16]

Figure 6 illustrates the importance of shattering fragmentation for structural characterization of peptide ions.[115] In the figure, the microcanonical dissociation rate constants for several peptides are compared with the onset for shattering fragmentation. The hatched and shadowed regions correspond to the experimental observation windows of QQ-SID and FT-ICR SID experiments, respectively. Shattering fragmentation is dominant when the internal energy of the ions exceeds the shattering threshold $(\sim 10 \mathrm{eV})$. Fragmentation of small peptides, illustrated using protonated pentaalanine as an example, is fairly fast at low internal excitations. As a result, small peptides predominately undergo unimolecular dissociation following collisions with surfaces. In contrast, shattering is predicted to compete with the unimolecular dissociation of larger peptides in FT-ICR SID experiments and to be the dominant process in QQ-SID experiments.

The width of the internal energy distribution deposited into the projectile ion determines the extent of mixing between the unimolecular and shattering fragmentation pathways in SID spectra. For example, the precursor ion, its primary fragments, and fragments originating from 
shattering were observed simultaneously in SID spectra of singly protonated peptides activated by collisions with a diamond surface, indicating facile mixing of different fragmentation channels.[116] This mixing of low- and high-energy dissociation pathways is attributed to the wide energy distributions deposited in collisions with diamond surfaces and is particularly advantageous for the structural characterization of complex molecules using SID.[117] In contrast, much narrower internal energy distributions deposited by collisions with SAM surfaces result in more selective formation of either low- or high-energy fragment ions in SID.

\section{Evidence of the Mobile Proton Model}

Collision-energy-resolved SID experiments played a key role in establishing the mobile proton model.[4, 5, 118-120] In these experiments, fragmentation efficiency curves (FECs) for protonated peptides were constructed from the experimental data by plotting the dependence of the fragmenting fraction of precursor ions as a function of collision energy. The relative position of FECs obtained for peptides of different sequences is determined by the amount of internal energy required to observe ion fragmentation on the experimental timescale. It has been demonstrated that FECs of peptides containing basic arginine and lysine residues are shifted toward higher energies, while FECs of doubly protonated peptides containing only one basic residue are shifted toward lower collision energies.[5, 118] These results indicate that higher internal excitations are necessary for proton mobilization in peptides containing one basic residue and one ionizing proton. This finding was rationalized by assuming that the ionizing proton is sequestered by the basic residue, while the second proton, initially located on the second most basic site, is more readily mobilized when the ion's internal energy increases during collision with a surface.[121]

\section{Energetics, Dynamics, and Mechanisms of Peptide Fragmentation}

SID also has been widely used for understanding peptide fragmentation mechanisms.[4, 5, 119, 121-131] For example, SID provided unique insights on the mechanisms of selective cleavages C-terminal to acidic residues. It has been demonstrated that FECs of peptides containing both basic (e.g. arginine, lysine, or histidine) and acidic residues (e.g. aspartic and glutamic acid) are shifted toward lower collision energies.[123, 124, 128] This observation combined with the unique fragmentation patterns of peptides containing acidic and basic residues 
was attributed to charge-remote fragmentation at acidic residues facilitated by the strong solvation of charged side chains by the nearby carboxylic groups.[119] FT-ICR SID studies confirmed that salt-bridge intermediates, in which the protonated arginine residue is solvated by carboxyl groups play an important role in dissociation of arginine-containing peptides.[127] Dissociation pathways involving SB intermediates produce the same reaction products as canonical pathways but are kinetically hindered.[127]

Time- and collision-energy-resolved SID experiments in FT-ICR combined with RRKMbased modeling of the experimental data $[132,133]$ revealed that selective cleavage at acidic residues is associated with relatively low dissociation threshold and large negative activation entropy.[128, 129] The kinetically hindered fragmentation at acidic residues is attributed to substantial rearrangements required to reach the transition state structure for dissociation. Similar results were obtained for selective fragmentation of peptides containing methionine sulfoxide residues.[134] FT-ICR SID also enabled the determination of the energetics and dynamics of individual dissociation pathways of protonated peptides, providing unique insights on the competition between backbone cleavage and small molecules loss (e.g., $\mathrm{H}_{2} \mathrm{O}$ and $\mathrm{NH}_{3}$ ) from different precursor ions.[125, 131]

FT-ICR SID of peptide radical cations and anions $\left(\mathrm{M}^{+\bullet}\right.$ and $\left.[\mathrm{M}-2 \mathrm{H}]^{-\bullet}\right)$ produced through

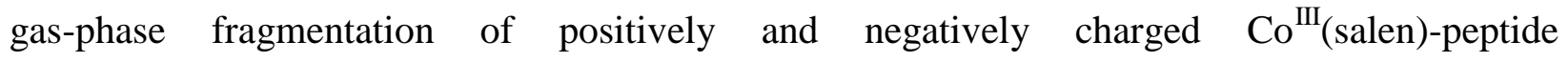
complexes, $[135,136]$ respectively, indicate that gas-phase fragmentation of peptide ions is an ergodic process.[137] Two populations of structures were identified in SID of $\mathrm{M}^{+\bullet}$ ions of angiotensin analogs,[138] while SID of the corresponding $[\mathrm{M}-2 \mathrm{H}]^{\bullet}$ ions could be adequately described using a single population of structures.[139] The two populations of radical cation structures were ascribed to the canonical and zwitterionic structures separated by a high barrier.[138] SID also provided the first quantitative account of the effect of the charge and radical on the energetics and dynamics of peptide fragmentation.[138, 139] It has been demonstrated that even-electron peptide ions containing basic arginine and histidine residues dissociate at higher collision energies than their odd-electron counterparts. RRKM modeling of SID data indicates that entropy effects are responsible for the reduced stability of the $[\mathrm{M}-2 \mathrm{H}]^{\bullet}$ ions toward fragmentation, while the reduced stability of the $\mathrm{M}^{+\bullet}$ ions is mainly determined by the lower dissociation threshold. 


\section{SID of Proteins and Protein Complexes}

Rapid excitation of ions in SID is particularly advantageous for the structural characterization of large proteins and protein complexes using MS/MS.[12] CID of such systems typically results in asymmetric fragmentation, where relatively small fragments carry disproportionately high charge.[140] For example, CID of protein multimers typically generates highly charged monomers as the most abundant fragments. This asymmetric charge partitioning in CID has been attributed to a partial protein unfolding prior to fragmentation.[140] Wysocki and co-workers hypothesized that fast vibrational excitation in ion-surface collision may facilitate fragmentation without protein unfolding. Indeed, the SID spectrum of cytochrome $\mathrm{C}$ dimer is dominated by symmetric charge partitioning expected for fragmentation without unfolding.[141] Similar results also were obtained for protein complexes of different sizes.[81, 142-146] Figure 7 compares CID and SID spectra of an $801 \mathrm{kDa}$ non-covalent tetradecamer protein, GroEL.[146] The CID spectrum is dominated by highly charged monomers and contains minor peaks corresponding to tridecamers (13mers). In contrast, SID generates a rich fragmentation pattern, providing valuable information about the complex topology and the interactions between individual subunits.[146] Furthermore, SID is much more efficient than CID for lower charge states of non-covalent protein complexes.[145, 146] Structural characterization of low charge state complexes further reduces unfolding of ions during fragmentation.[144] For the GroEL complex in the +50 charge state, no fragments were observed using CID. However, SID generated abundant heptamer fragments representing the complex's native topology, which also were observed as minor fragments in SID of the +71 charge state.

\section{Soft and Reactive Landing of Polyatomic Ions}

Soft landing of mass-selected ions is a powerful approach for the controlled preparation of ultrathin films on substrates and the purification of compounds from complex mixtures through deposition into solid or liquid matrices.[6-11, 15, 27, 29, 90] The advantages of massselected ion deposition over other surface modification approaches include the ability to introduce large molecules into the gas phase without fragmentation and significant structural rearrangement, highly specific separation of ions of interest using a mass spectrometer as a separation device, precise control of an ion's kinetic energy and the shape and size of the deposition area achieved using ion beam focusing and patterning, and uniform coverage of ions 
over the deposition area. Although a majority of soft landing studies are performed by placing the substrate into vacuum, Cooks and co-workers recently introduced ambient soft landing,[147, 148] which may substantially reduce the cost and increase the throughput of ion deposition applications.

The term "soft landing" refers to the process in which intact ions are deposited onto surfaces with or without charge retention.[39] Dissociative landing is a competing process, where fragments of the precursor ion are trapped on the surface.[99] Reactive landing is the third competing process that results in covalent bond formation between the ion and surface.[149] Often, the formation of a strong electrostatic bond between the ion and surface is classified as reactive landing. The competition between these processes is determined by the precursor ion's structure, stability, and kinetic energy and the surface properties. For example, dissociative landing of relatively small ions on SAMs was observed at collision energies below $10 \mathrm{eV}$ (ion velocity of $\sim 3800 \mathrm{~m} / \mathrm{s}$ ), [99] while large peptide ions were deposited intact at $150 \mathrm{eV}$ collision energy (ion velocity of $\sim 5300 \mathrm{~m} / \mathrm{s}$ ) onto SAM surfaces.[150] Dissociative landing is expected to be a dominant process in collisions with stiff surfaces, where a significant fraction of the kinetic energy is converted into the internal excitation of the ion followed by fragmentation.[93, 103] Molecular dynamics simulations of energy transfer in collisions of small hydrocarbon cations with polystyrene surfaces indicate that for ions remaining on the surface, $97-98 \%$ of ion's kinetic energy is transferred to the surface and only 2-3\% into the ion's vibrational excitation.[151] In contrast, ions scattered off the surface transfer $\sim 84 \%$ of their initial kinetic energy to the surface, indicating differences in the dynamics of ion scattering and deposition.

Reactive landing occurs when the projectile ion contains a functional group that may react with the terminal surface group.[15] Several solution-phase reactions have been mimicked using reactive landing of gaseous ions including Kolbe-Schmitt carboxylation reaction[149], silylation, esterification and ether formation at hydroxyl-terminated SAMs (HO-SAM),[152, 153] amine-ester[154-156] and amine-acyl halide reactions,[52] and amide bond formation between $\mathrm{Cr}$ (aniline) $)_{2}$ complexes and COOH-SAMs.[157] In addition, the formation of strong electrostatic interactions has been observed for relatively small organic ions and proteins deposited on plasma-treated metal surfaces $[43,158]$ and for undercoordinated $\mathrm{Ru}(\mathrm{bpy})_{2}{ }^{2+}$ ions deposited on COOH-SAM.[48, 159] 
Examples of soft, dissociative, and reactive landing applications include: selective deposition of organic and organometallic ions; $[39,99,149,152,158-163]$ thin film growth and polymer modification using hyperthermal ions,[27, 151, 164] chiral enrichment of serine,[165] deposition of mass-selected cluster ions, [23, 45, 59, 90, 91, 166-169] preparation of protein and peptide arrays, $[41,150,170,171]$ determination of the tertiary structure of proteins and protein complexes,[55, 60] selective deposition of proteins, DNA and viruses with retention of biological activity [41, 43, 170, 172, 173] preparation of novel carbon-based materials, [40, 44, 174-176] fabrication of metal oxide surfaces for phosphopeptide enrichment,[177] fabrication of SERS substrates,[178] investigation of transport properties of small ions through liquid films [54, 179] and proton-mediated chemistry on surfaces,[180] understanding conformational changes and chiral amplification on surfaces, $[56,171,181,182]$ and observation of molecular magnetism.[183]

\section{Soft and Reactive Landing Efficiency}

Soft landing efficiency is determined by the ion's chemical properties, physical and chemical properties of the surface (e.g., temperature, roughness, stiffness, and terminal functional groups), and the ion's kinetic energy. Early studies by Cooks and co-workers demonstrated that sterically bulky closed-shell ions may be deposited intact onto FSAM surfaces, while radical cations and small even-electron ions were not retained on surfaces.[39, 99] In contrast, $\mathrm{D}_{3} \mathrm{O}^{+}$ions are efficiently trapped on liquid surfaces cooled to $<200$ K.[54] These results can be rationalized by assuming the rate constant for evaporation of molecules from surfaces is given by the Arrhenius equation and considering the binding energy to the surface increases with the projectile ion's size and complexity. Time-dependent SIMS analysis of FSAM surfaces after soft landing of peptide ions indicated slow evaporation of ions from surfaces.[150, $184]$ The binding energy of $\sim 20 \mathrm{kcal} / \mathrm{mol}$ was derived from these experiments.[150]

Figure 8 shows the dependence of the relative soft and reactive landing efficiency on the ion's kinetic energy.[150,155] The soft landing efficiency (Figure 8a) shows a slow gradual decrease with an increase in the incident collision energy up to $\sim 80 \mathrm{eV}$.[150] In contrast, because reactive landing is associated with a barrier, the reactive landing efficiency increases at low collision energies (Figure 8b).[150, 153, 185] Figure 8 also illustrates that both the soft and reactive landing efficiencies decrease at higher collision energies. This decrease is attributed to 
the increasing role of scattering and SID at higher collision energies. These results indicate that soft landing is most efficient at low collision energies, while the reactive landing efficiency has an optimal range of collision energies that depends on the reaction barrier height. Reactive landing is promoted by the ion's kinetic energy, which can be readily adjusted to maximize the efficiency of the covalent attachment to surfaces. Similar coverage of $\sim 60 \%$ was reported for c(RGDfK-) covalently attached to the N-hydroxysuccinimidyl ester-terminated SAM (NHS-SAM) surface using $4 \mathrm{hr}$ reactive landing and $2 \mathrm{hr}$ reaction in solution.[154] Much higher relative yield of covalent immobilization was observed in reactive landing of the GRGDSPK peptide that showed very inefficient reaction in solution.[155]

\section{Charge Reduction/Retention}

Using mass spectrometry as a preparatory tool for controlled preparation of surfaces with desired properties requires understanding of the effect of surface immobilization on the structure and charge state-hence, the reactivity - of the deposited species. The exciting discovery of charge retention by soft-landed closed-shell ions on FSAMs[39, 99] has triggered a number of studies focused on understanding charge retention/reduction on surfaces.[162, 184, 186-188] It has been established that FSAMs efficiently retain ions. Superior charge retention properties of FSAMs are attributed to the interface dipoles that efficiently block electron transport through the layer at low potentials.[188] Two charge reduction mechanisms have been discussed in the literature: 1) loss of the ionizing proton by the singly or multiply protonated complex molecule[184, 186] and 2) loss of charge involving electron tunneling through the insulating layer on the surface followed by electron attachment to the positive ion. $[162,187,188]$ The first

process is a major decay channel for protonated molecules deposited onto SAMs while. The second process is particularly important for charge reduction by cations lacking the ionizing proton.

Charge retention by soft-landed ions results in a potential buildup on the surface. Cowin and co-workers used a Kelvin probe to directly measure this potential for studying ion diffusion through organic and aqueous liquid layers.[54, 179] Up to $10 \mathrm{~V}$ potential across micron-thick liquid layers could be established using ion soft landing without electrical discharge through the layer. In contrast, SAMs are very thin $(\sim 1 \mathrm{~nm})$, insulating layers that cannot withstand these potentials. It has been observed experimentally that deposition of triply charged ligated gold 
cluster cations onto FSAM surfaces may induce electron tunneling through FSAM by building up a potential of $\sim 1 \mathrm{~V}$ across the monolayer.[188] At low ion coverage, FSAM efficiently retains the deposited ions. At higher coverage, the deposited triply charged ion is significantly depleted, and the doubly charged ion becomes the dominant species.[187, 188] In contrast, HSAM surfaces do not retain the triply charged ions and, as a result, do not show significant charge buildup during ion deposition. Charge loss from permanent ions on HSAM surfaces is attributed to the relatively efficient electron tunneling through this layer that facilitates charge reduction.

\section{Secondary and Tertiary Structures of Complex Molecules on Surfaces}

In 2004, Cooks and co-workers demonstrated that intact proteins soft landed onto liquid surfaces retain their biological activity.[41, 170] These studies showed that desolvation of protein ions during ESI and transfer through the vacuum system for deposition may have a relatively minor effect on the secondary and tertiary structure of complex biological molecules. Subsequent studies used soft landing experiments to characterize the secondary and tertiary structures of complex molecules deposited on surfaces with a level of detail not attainable using traditional deposition approaches. IRRAS characterization of the secondary structures of soft landed polyalanines has shown that soft and reactive landing may be used for preparation of $\alpha$ helical peptide films that cannot be prepared by absorption of a peptide from solution.[171, 182] For example, Figure 9 shows IRRAS spectra obtained for the $\mathrm{AcA}_{15} \mathrm{~K}$ peptide deposited onto an FSAM surface from solution and from the gas phase.[171] Distinctly different infrared bands were obtained for the gas- and solution-phase depositions. Primarily, the amine I band shape indicates that a mixture of the $\beta$-sheet, $\alpha$-helix, and globular conformations is deposited from solution. Meanwhile, ion soft landing yields a narrow amide I band corresponding to the $\alpha$ helical conformation. This result demonstrated the unique power of ion soft landing for the selective preparation of conformationally selected peptide arrays.

Secondary structures of soft-landed proteins have been examined using STM.[55] In that study, compact and extended conformations of cytochrome $\mathrm{C}$ were deposited onto clean metal surfaces by selecting the protein's respective low and high charge states using a quadrupole mass spectrometer as a filter. Figure 10 shows STM images of cytochrome $\mathrm{C}$ in the low and high charge states deposited onto the strongly interacting $\mathrm{Cu}(001)$ and relatively weakly interacting $\mathrm{Au}$ (111) surfaces. STM of deposited proteins indicates that a fraction of folded proteins retain 
their three-dimensional structure on both metal surfaces. In addition, unfolding and agglomeration of the unfolded conformations also was observed. Unfolded proteins deposited onto the $\mathrm{Cu}$ (001) surface are observed as extended string-like species, while more compact conformations are observed on the $\mathrm{Au}$ (111) surface. These results indicate that unfolded proteins undergo partial folding, forming unique, two-dimensional conformations on the Au (111) surface.[55]

TEM provided the first visualization of the large GroEL protein complex's tertiary structures. In that study, the GroEL complex was generated using native mass spectrometry and deposited onto TEM grids using ion soft landing.[60] Although this field still is in its infancy, the results demonstrate the potential of preparatory mass spectrometry for structural characterization of well-defined biomolecular complexes on substrates.

\section{Conclusions and Outlook}

Collisions of polyatomic ions with surfaces have been systematically investigated for more than 30 years. These studies have resulted in development of SID as a powerful tool for the structural characterization of complex molecules, as well as for detailed understanding of the energetics and mechanisms of gas-phase fragmentation of large molecules. Future SID applications will focus on quantitative studies of non-covalent interactions and structural characterization of large protein complexes using mass spectrometry. Detailed and progressive understanding of the physical and chemical processes underlying soft and reactive landing of mass-selected ions provided the foundation for preparatory mass spectrometry. With advanced development of ionization sources, preparatory mass spectrometry may be transformed into a widely used technique for surface modification complementary to solution-phase deposition and molecular beam epitaxy. Some of the most promising future applications of preparatory mass spectrometry include fabrication of catalytically active substrates, thin film ultracapacitors and magnetic devices, and separation and structural characterization of large biomolecular complexes, among others.

\section{Acknowledgments}

I would like to thank all of the students, postdoctoral fellows, and colleagues who contributed to development of the research area described in this perspective article. In 
particular, I express my appreciation to my former research advisor, Dr. Jean Futrell, who introduced me to this field, as well as current group members Drs. Grant Johnson and Don Gunaratne and former group members Drs. Eduard Denisov, Sergey Rakov, Anil Shukla, Omar Hadjar, Peng Wang, Zhibo Yang, and Qichi Hu-who all worked on various aspects of ionsurface collisions. I also thank Profs. Graham Cooks, Bill Hase, and Vicki Wysocki for helpful discussions and continued collaboration. Our ongoing research involving ion-surface collisions in mass spectrometry is supported by the U.S. Department of Energy (DOE), Office of Basic Energy Sciences, Chemical Sciences, Geosciences \& Biosciences Division. The research is performed using EMSL, a national scientific user facility sponsored by the DOE's Office of Biological and Environmental Research and located at Pacific Northwest National Laboratory (PNNL). PNNL is operated by Battelle for the DOE under Contract DE-AC05-76RL01830. 


\section{References}

[1] J.J. Thomson, Rays of positive electricity and their application to chemical analyses, Longmans, Green and Co., London, New York, 1913.

[2] V. Franchetti, B.H. Solka, W.E. Baitinger, J.W. Amy, R.G. Cooks, Soft Landing of Ions as a Means of Surface Modification, International Journal of Mass Spectrometry and Ion Processes 23 (1977) 29-35.

[3] M.D.A. Mabud, M.J. Dekrey, R.G. Cooks, Surface-induced dissociation of molecular ions, International Journal of Mass Spectrometry and Ion Processes 67 (1985) 285-294.

[4] A.R. Dongre, A. Somogyi, V.H. Wysocki, Surface-induced dissociation: An effective tool to probe structure, energetics and fragmentation mechanisms of protonated peptides, Journal of Mass Spectrometry 31 (1996) 339-350.

[5] A.R. Dongre, J.L. Jones, A. Somogyi, V.H. Wysocki, Influence of peptide composition, gasphase basicity, and chemical modification on fragmentation efficiency: Evidence for the mobile proton model, Journal of the American Chemical Society 118 (1996) 8365-8374.

[6] V. Grill, J. Shen, C. Evans, R.G. Cooks, Collisions of ions with surfaces at chemically relevant energies: Instrumentation and phenomena, Review of Scientific Instruments 72 (2001) 31493179 .

[7] B. Gologan, J.M. Wiseman, R.G. Cooks, Ion Soft Landing: Instrumentation, Phenomena, and Applications, in: J. Laskin, C. Lifshitz, (Eds.), Principles of Mass Spectrometry Applied to Biomolecules, John Wiley \& Sons., Inc., Hoboken, NJ, 2006.

[8] J. Cyriac, T. Pradeep, H. Kang, R. Souda, R.G. Cooks, Low-Energy Ionic Collisions at Molecular Solids, Chemical Reviews 112 (2012) 5356-5411.

[9] J. Laskin, P. Wang, O. Hadjar, Soft-landing of peptide ions onto self-assembled monolayer surfaces: an overview, Physical Chemistry Chemical Physics 10 (2008) 1079-1090.

[10] G.E. Johnson, Q.C. Hu, J. Laskin, Soft Landing of Complex Molecules on Surfaces, Annual Review of Analytical Chemistry 4 (2011) 83-104.

[11] G. Verbeck, W. Hoffmann, B. Walton, Soft-landing preparative mass spectrometry, Analyst 137 (2012) 4393-4407.

[12] V.H. Wysocki, K.E. Joyce, C.M. Jones, R.L. Beardsley, Surface-induced dissociation of small molecules, peptides, and non-covalent protein complexes, Journal of the American Society for Mass Spectrometry 19 (2008) 190-208.

[13] R.G. Cooks, T. Ast, A. Mabud, Collisions of polyatomic ions with surfaces, International Journal of Mass Spectrometry 100 (1990) 209-265.

[14] R.G. Cooks, T. Ast, T. Pradeep, V. Wysocki, Reactions of ions with organic surfaces, Accounts of Chemical Research 27 (1994) 316-323.

[15] P. Wang, J. Laskin, Surface Modification Using Reactive Landing of Mass-Selected Ions, in: R. Hellborg, H.J. Whitlow, Y. Zhang, (Eds.), Ion Beams in Nanoscience and Technology, Springer, London, New York, 2009.

[16] T. Raz, R.D. Levine, On the shattering of clusters by surface impact heating, Journal of Chemical Physics 105 (1996) 8097-8102.

[17] W. Christen, U. Even, T. Raz, R.D. Levine, Collisional energy loss in cluster surface impact: Experimental, model, and simulation studies of some relevant factors, Journal of Chemical Physics 108 (1998) 10262-10273.

[18] W. Christen, U. Even, Cluster impact chemistry, Journal of Physical Chemistry A 102 (1998) 9420-9426.

[19] R.D. Beck, C. Warth, K. May, M.M. Kappes, Surface impact induced shattering of C-60. Detection of small C-m fragments by negative surface ionization, Chemical Physics Letters 257 (1996) 557-562. 
[20] O. Meroueh, W.L. Hase, Effect of surface stiffness on the efficiency of surface-induced dissociation, Physical Chemistry Chemical Physics 3 (2001) 2306-2314.

[21] J. Laskin, T.H. Bailey, J.H. Futrell, Shattering of peptide ions on self-assembled monolayer surfaces, Journal of the American Chemical Society 125 (2003) 1625-1632.

[22] T. Ast, D.E. Riederer, S.A. Miller, M. Morris, R.G. Cooks, Collisions of fluorocarbon ions at solid-surfaces - electronic excitation, surface-induced dissociation and chemical sputtering, Organic Mass Spectrometry 28 (1993) 1021-1033.

[23] C. Xirouchaki, R.E. Palmer, Pinning and implantation of size-selected metal clusters: a topical review, Vacuum 66 (2002) 167-173.

[24] N. Winograd, B.J. Garrison, Biological Cluster Mass Spectrometry, in: S.R. Leone, P.S. Cremer, J.T. Groves, M.A. Johnson, G. Richmond, (Eds.), Annual Review of Physical Chemistry, Vol 61, Annual Reviews, Palo Alto, 2010, pp. 305-322.

[25] R.J. Day, S.E. Unger, R.G. Cooks, Molecular secondary ion mass-spectrometry, Analytical Chemistry 52 (1980) A557-\&.

[26] A. Benninghoven, Chemical-analysis of inorganic and organic-surfaces and thin-films by static time-of-flight secondary-ion mass-spectrometry (TOF-SIMS), Angewandte Chemie-International Edition in English 33 (1994) 1023-1043.

[27] L. Hanley, S.B. Sinnott, The growth and modification of materials via ion-surface processing, Surface Science 500 (2002) 500-522.

[28] D.C. Jacobs, Reactive collisions of hyperthermal energy molecular ions with solid surfaces, Annual Review of Physical Chemistry 53 (2002) 379-407.

[29] B. Gologan, J.R. Green, J. Alvarez, J. Laskin, R.G. Cooks, Ion/surface reactions and ion softlanding, Physical Chemistry Chemical Physics 7 (2005) 1490-1500.

[30] R.W. Gurney, The scattering of positive ions from a platinum surface, Physical Review 32 (1928) 0467-0477.

[31] C.C. Van Voorhis, K.T. Compton, Accommodation coefficients of positive ions of argon, neon and helium, Physical Review 37 (1931) 1596-1610.

[32] K.S. Woodcock, The emission of negative ions under the bombardment of positive ions, Physical Review 38 (1931) 1696-1703.

[33] R.E. Honig, The development of secondary ion mass-spectrometry (SIMS) - A retrospective, International Journal of Mass Spectrometry and Ion Processes 66 (1985) 31-54.

[34] J.H. Beynon, A.E. Fontaine, G.R. Lester, An anomalous metastable peak in mass spectrum of methanol, Chemical Communications (1968) 265-\&.

[35] R.G. Cooks, Metastable ions, Elsevier Scientific Pub. Co., 1973.

[36] C. Lifshitz, M. Shapiro, Sternber.R, Isotope effects on metastable transitions .4. Isotopic methanols, Israel Journal of Chemistry 7 (1969) 391-\&.

[37] R.G. Cooks, T. Ast, J.H. Beynon, Anomalous metastable peaks, International Journal of Mass Spectrometry and Ion Processes 16 (1975) 348-352.

[38] R.G. Cooks, D.T. Terwilliger, T. Ast, J.H. Beynon, T. Keough, Surface modified massspectrometry, Journal of the American Chemical Society 97 (1975) 1583-1585.

[39] S.A. Miller, H. Luo, S.J. Pachuta, R.G. Cooks, Soft-landing of polyatomic ions at fluorinated self-assembled monolayer surfaces, Science 275 (1997) 1447-1450.

[40] A. Bottcher, P. Weis, S.S. Jester, D. Loffler, A. Bihlmeier, W. Klopper, M.M. Kappes, Solid C58 films, Physical Chemistry Chemical Physics 7 (2005) 2816-2820.

[41] Z. Ouyang, Z. Takats, T.A. Blake, B. Gologan, A.J. Guymon, J.M. Wiseman, J.C. Oliver, V.J. Davisson, R.G. Cooks, Preparing protein microarrays by soft-landing of mass-selected ions, Science 301 (2003) 1351-1354.

[42] J. Alvarez, R.G. Cooks, S.E. Barlow, D.J. Gaspar, J.H. Futrell, J. Laskin, Preparation and in situ characterization of surfaces using soft landing in a Fourier transform ion cyclotron resonance mass spectrometer, Analytical Chemistry 77 (2005) 3452-3460. 
[43] M. Volny, W.T. Elam, A. Branca, B.D. Ratner, F. Turecek, Preparative soft and reactive landing of multiply charged protein ions on a plasma-treated metal surface, Analytical Chemistry 77 (2005) 4890-4896.

[44] H.J. Rader, A. Rouhanipour, A.M. Talarico, V. Palermo, P. Samori, K. Mullen, Processing of giant graphene molecules by soft-landing mass spectrometry, Nature Materials 5 (2006) 276-280.

[45] R.E. Palmer, S. Pratontep, H.G. Boyen, Nanostructured surfaces from size-selected clusters, Nature Materials 2 (2003) 443-448.

[46] U. Heiz, F. Vanolli, L. Trento, W.D. Schneider, Chemical reactivity of size-selected supported clusters: An experimental setup, Review of Scientific Instruments 68 (1997) 1986-1994.

[47] S. Vajda, M.J. Pellin, J.P. Greeley, C.L. Marshall, L.A. Curtiss, G.A. Ballentine, J.W. Elam, S. Catillon-Mucherie, P.C. Redfern, F. Mehmood, P. Zapol, Subnanometre platinum clusters as highly active and selective catalysts for the oxidative dehydrogenation of propane, Nature Materials 8 (2009) 213-216.

[48] G.E. Johnson, M. Lysonski, J. Laskin, In situ reactivity and TOF-SIMS analysis of surfaces prepared by soft and reactive landing of mass-selected ions, Analytical Chemistry 82 (2010) 5718-5727.

[49] Z.X. Nie, G.T. Li, M.P. Goodwin, L. Gao, J. Cyriac, R.G. Cooks, In Situ SIMS Analysis and Reactions of Surfaces Prepared by Soft Landing of Mass-Selected Cations and Anions Using an Ion Trap Mass Spectrometer, Journal of the American Society for Mass Spectrometry 20 (2009) 949-956.

[50] J. Cyriac, M. Wleklinski, G.T. Li, L. Gao, R.G. Cooks, In situ Raman spectroscopy of surfaces modified by ion soft landing, Analyst 137 (2012) 1363-1369.

[51] M. Volny, A. Sengupta, C.B. Wilson, B.D. Swanson, E.J. Davis, F. Turecek, Surface-enhanced Raman spectroscopy of soft-landed polyatomic ions and molecules, Analytical Chemistry 79 (2007) 4543-4551.

[52] Q.C. Hu, P. Wang, P.L. Gassman, J. Laskin, In situ studies of soft- and reactive landing of massselected ions using infrared reflection absorption spectroscopy, Analytical Chemistry 81 (2009) $7302-7308$.

[53] S. Nagaoka, T. Matsumoto, K. Ikemoto, M. Mitsui, A. Nakajima, Soft-landing isolation of multidecker V-2(benzene)(3) complexes in an organic monolayer matrix: An infrared spectroscopy and thermal desorption study, Journal of the American Chemical Society 129 (2007) 1528-+.

[54] J.P. Cowin, A.A. Tsekouras, M.J. Iedema, K. Wu, G.B. Ellison, Immobility of protons in ice from 30 to 190 K, Nature 398 (1999) 405-407.

[55] Z.T. Deng, N. Thontasen, N. Malinowski, G. Rinke, L. Harnau, S. Rauschenbach, K. Kern, A Close Look at Proteins: Submolecular Resolution of Two- and Three-Dimensionally Folded Cytochrome c at Surfaces, Nano Letters 12 (2012) 2452-2458.

[56] N. Hauptmann, K. Scheil, T.G. Gopakumar, F.L. Otte, C. Schütt, R. Herges, R. Berndt, Surface Control of Alkyl Chain Conformations and 2D Chiral Amplification, Journal of the American Chemical Society 135 (2013) 8814-8817.

[57] N. Bajales, S. Schmaus, T. Miyamashi, W. Wulfhekel, J. Wilhelm, M. Walz, M. Stendel, A. Bagrets, F. Evers, S. Ulas, B. Kern, A. Bottcher, M.M. Kappes, C-58 on Au(111): A scanning tunneling microscopy study, Journal of Chemical Physics 138 (2013).

[58] S. Ulas, D. Loffler, P. Weis, A. Bottcher, M.M. Kappes, Desorption of C-60 upon thermal decomposition of cesium C-58 fullerides, Journal of Chemical Physics 136 (2012).

[59] G.E. Johnson, C. Wang, T. Priest, J. Laskin, Monodisperse $\mathrm{Au}_{11}$ clusters prepared by soft landing of mass selected ions, Analytical Chemistry 83 (2011) 8069-8072.

[60] J.L.P. Benesch, B.T. Ruotolo, D.A. Simmons, N.P. Barrera, N. Morgner, L. Wang, H.R. Saibil, C.V. Robinson, Separating and visualising protein assemblies by means of preparative mass spectrometry and microscopy, Journal of Structural Biology 172 (2010) 161-168. 
[61] M.E. Bier, J.W. Amy, R.G. Cooks, J.E.P. Syka, P. Ceja, G. Stafford, A tandem quadrupole massspectrometer for the study of surface-induced dissociation, International Journal of Mass Spectrometry and Ion Processes 77 (1987) 31-47.

[62] V.H. Wysocki, J.M. Ding, J.L. Jones, J.H. Callahan, F.L. King, Surface-induced dissociation in tandem quadrupole mass spectrometers - a comparison of 3 designs, Journal of the American Society for Mass Spectrometry 3 (1992) 27-32.

[63] Z. Ouyang, V. Grill, J. Alvarez, C.H. Doerge, L. Gianelli, P. Thomas, H.W. Rohrs, R.G. Cooks, A multiquadrupole tandem mass spectrometer for the study of ion/surface collision processes, Review of Scientific Instruments 73 (2002) 2375-2391.

[64] M.E. Bier, J.C. Schwartz, K.L. Schey, R.G. Cooks, Tandem mass-spectrometry using an in-line ion surface collision device, International Journal of Mass Spectrometry and Ion Processes 103 (1990) 1-19.

[65] A.S. Galhena, S. Dagan, C.M. Jones, R.L. Beardsley, V.N. Wysocki, Surface-induced dissociation of peptides and protein complexes in a quadrupole/Time-of-Flight mass spectrometer, Analytical Chemistry 80 (2008) 1425-1436.

[66] K.L. Schey, D.A. Durkin, K.R. Thornburg, DESIGN AND PERFORMANCE OF AN IN-LINE SURFACE-INDUCED DISSOCIATION DEVICE IN A 4-SECTOR MASS-SPECTROMETER, Journal of the American Society for Mass Spectrometry 6 (1995) 257-263.

[67] S.A. Lammert, R.G. Cooks, Surface-induced dissociation of molecular-ions in a quadrupole ion trap mass-spectrometer, Journal of the American Society for Mass Spectrometry 2 (1991) 487491.

[68] B.E. Winger, H.J. Laue, S.R. Horning, R.K. Julian, S.A. Lammert, D.E. Riederer, R.G. Cooks, Hybrid BEEQ tandem mass-spectrometer for the study of ion surface collision processes, Review of Scientific Instruments 63 (1992) 5613-5625.

[69] K. Schey, R.G. Cooks, R. Grix, H. Wollnik, A tandem time-of-flight mass-spectrometer for surface-induced dissociation, International Journal of Mass Spectrometry and Ion Processes 77 (1987) 49-61.

[70] L.L. Haney, D.E. Riederer, Delayed extraction for improved resolution of ion/surface collision products by time-of-flight mass spectrometry, Analytica Chimica Acta 397 (1999) 225-233.

[71] E. Stone, K.J. Gillig, B. Ruotolo, K. Fuhrer, M. Gonin, A. Schultz, D.H. Russell, Surface-induced dissociation on a MALDI-ion mobility-orthogonal time-of-flight mass spectrometer: Sequencing peptides from an "in-solution" protein digest, Analytical Chemistry 73 (2001) 2233-2238.

[72] C.M. Gamage, F.M. Fernandez, K. Kuppannan, V.H. Wysocki, Submicrosecond surface-induced dissociation of peptide ions in a MALDI TOF MS, Analytical Chemistry 76 (2004) 5080-5091.

[73] E.N. Nikolaev, A. Somogyi, D.L. Smith, C.G. Gu, V.H. Wysocki, C.D. Martin, G.L. Samuelson, Implementation of low-energy surface-induced dissociation (eV SID) and high-energy collisioninduced dissociation (keV CID) in a linear sector-TOF hybrid tandem mass spectrometer, International Journal of Mass Spectrometry 212 (2001) 535-551.

[74] C.F. Ijames, C.L. Wilkins, SURFACE-INDUCED DISSOCIATION BY FOURIERTRANSFORM MASS-SPECTROMETRY, Analytical Chemistry 62 (1990) 1295-1299.

[75] J. Laskin, E.V. Denisov, A.K. Shukla, S.E. Barlow, J.H. Futrell, Surface-induced dissociation in a Fourier transform ion cyclotron resonance mass spectrometer: Instrument design and evaluation, Analytical Chemistry 74 (2002) 3255-3261.

[76] R.A. Chorush, D.P. Little, S.C. Beu, T.D. Wood, F.W. McLafferty, SURFACE-INDUCED DISSOCIATION OF MULTIPLY PROTONATED PROTEINS, Analytical Chemistry 67 (1995) 1042-1046.

[77] W.Q. Zhong, E.N. Nikolaev, J.H. Futrell, V.H. Wysocki, Tandem Fourier transform mass spectrometry studies of surface-induced dissociation of benzene monomer and dimer ions on a self-assembled fluorinated alkanethiolate monolayer surface, Analytical Chemistry 69 (1997) 2496-2503. 
[78] V.S. Rakov, J.H. Futrell, E.V. Denisov, E.N. Nikolaev, Instrumentation of kinetic energyresolved surface-induced dissociation in Fourier transform mass spectrometry, European Journal of Mass Spectrometry 6 (2000) 299-317.

[79] W.J. Sun, J.C. May, D.H. Russell, A novel surface-induced dissociation instrument for ion mobility-time-of-flight mass spectrometry, International Journal of Mass Spectrometry 259 (2007) 79-86.

[80] W.J. Sun, J.C. May, K.J. Gillig, D.H. Russell, A dual time-of-flight apparatus for an ion mobilitysurface-induced dissociation-mass spectrometer for high-throughput peptide sequencing, International Journal of Mass Spectrometry 287 (2009) 39-45.

[81] M.W. Zhou, C.S. Huang, V.H. Wysocki, Surface-Induced Dissociation of Ion Mobility-Separated Noncovalent Complexes in a Quadrupole/Time-of-Flight Mass Spectrometer, Analytical Chemistry 84 (2012) 6016-6023.

[82] A. Budrevich, B. Tsipinyuk, A. Bekkerman, E. Kolodney, Surface scattering of hyperthermal (10$50 \mathrm{eV}$ ) neutral C-60: Angular and energy distributions, Journal of Chemical Physics 106 (1997) 5771-5774.

[83] J. Kubista, Z. Dolejsek, Z. Herman, Energy partitioning in collisions of slow polyatomic ions with surfaces: ethanol molecular ions on stainless steel surfaces, European Mass Spectrometry 4 (1998) 311-319.

[84] R. Worgotter, J. Kubista, J. Zabka, Z. Dolejsek, T.D. Mark, Z. Herman, Surface-induced reactions and decomposition of the benzene molecular ion C6H6+: Product ion intensities, angular and translational energy distributions, International Journal of Mass Spectrometry 174 (1998) 53-62.

[85] H.L. de Clercq, A.D. Sen, A.K. Shukla, J.H. Futrell, Inelastic ion-surface collisions: scattering and dissociation of low energy benzene molecular cations, International Journal of Mass Spectrometry 212 (2001) 491-504.

[86] A.K. Shukla, J.H. Futrell, A beam scattering instrument for the dynamics studies of surfaceinduced dissociation processes, Review of Scientific Instruments 74 (2003) 168-175.

[87] B.E. Winger, R.K. Julian, R.G. Cooks, C.E.D. Chidsey, Surface-reactions and surface-induced dissociation of polyatomic ions at self-assembled organic monolayer surfaces, Journal of the American Chemical Society 113 (1991) 8967-8969.

[88] V.H. Wysocki, J.L. Jones, J.M. Ding, Polyatomic ion/surface collisions at self-assembled monolayers films, Journal of the American Chemical Society 113 (1991) 8969-8970.

[89] J. Laskin, J.H. Futrell, Energy transfer in collisions of peptide ions with surfaces, Journal of Chemical Physics 119 (2003) 3413-3420.

[90] U. Heiz, E.L. Bullock, Fundamental aspects of catalysis on supported metal clusters, Journal of Materials Chemistry 14 (2004) 564-577.

[91] D.-C. Lim, C.-C. Hwang, G. Gantefor, Y.D. Kim, Model catalysts of supported Au nanoparticles and mass-selected clusters, Physical Chemistry Chemical Physics 12 (2010) 15172-15180.

[92] Z. Herman, Collisions of slow polyatomic ions with surfaces: The scattering method and results, Journal of the American Society for Mass Spectrometry 14 (2003) 1360-1372.

[93] K.Y. Song, O. Meroueh, W.L. Hase, Dynamics of $\mathrm{Cr}(\mathrm{CO})_{6}{ }^{+}$collisions with hydrogenated surfaces, Journal of Chemical Physics 118 (2003) 2893-2902.

[94] J. Kubišta, Z. Dolejšek, Z. Herman, Energy partitioning in collisions of slow polyatomic ions with surfaces: ethanol molecular ions on stainless steel surfaces, European Journal of Mass Spectrometry 4 (1998) 311-319.

[95] R. Wörgötter, J. Kubišta, J. Žabka, Z. Dolejšek, T.D. Märk, Z. Herman, Surface-induced reactions and decomposition of the benzene molecular ion C6H6+: Product ion intensities, angular and translational energy distributions, International Journal of Mass Spectrometry and Ion Processes 174 (1998) 53-62.

[96] J. Roithova, J. Zabka, Z. Dolejsek, Z. Herman, Collisions of slow polyatomic ions with surfaces: Dissociation and chemical reactions of $\mathrm{CD} 5+, \mathrm{CD} 4+$ center dot, $\mathrm{CD} 3+$, and their isotopic variants 
on room-temperature and heated carbon surfaces, Journal of Physical Chemistry B 106 (2002) 8293-8301.

[97] A.K. Shukla, J.H. Futrell, Dynamics of hyperthermal energy ion-surface collisions: dissociative and non-dissociative scattering of ethanol cations from a self-assembled monolayer surface of fluorinated alkyl thiol on Au(111), International Journal of Mass Spectrometry 223 (2003) 783801.

[98] A.K. Shukla, J.H. Futrell, A.D. Sen, Dynamics of the dissociative and nondissociative scattering of hyperthermal CS2+ from a self-assembled fluoroalkyl monolayer surface on gold substrate, Journal of Chemical Physics 118 (2003) 11217-11225.

[99] J.W. Shen, Y.H. Yim, B.B. Feng, V. Grill, C. Evans, R.G. Cooks, Soft landing of ions onto selfassembled hydrocarbon and fluorocarbon monolayer surfaces, International Journal of Mass Spectrometry 183 (1999) 423-435.

[100] D.L. Smith, V.H. Wysocki, R. Colorado, O.E. Shmakova, M. Graupe, T.R. Lee, Low-energy ionsurface collisions characterize alkyland fluoroalkyl-terminated self-assembled monolayers on gold, Langmuir 18 (2002) 3895-3902.

[101] J. Zabka, Z. Dolejsek, Z. Herman, Energy partitioning in collisions of slow polyatomic ions with surfaces: Ethanol molecular ions on surfaces covered by self-assembled monolayers (CF-SAM, CH-SAM, COOH-SAM), Journal of Physical Chemistry A 106 (2002) 10861-10869.

[102] J. Laskin, E. Denisov, J. Futrell, A comparative study of collision-induced and surface-induced dissociation. 1. Fragmentation of protonated dialanine, Journal of the American Chemical Society 122 (2000) 9703-9714.

[103] O. Meroueh, W.L. Hase, Dynamics of energy transfer in peptide-surface collisions, Journal of the American Chemical Society 124 (2002) 1524-1531.

[104] S.B.M. Bosio, W.L. Hase, Simulations of energy transfer in $\operatorname{Cr}(\mathrm{CO})(6)(+)$ surface-induced dissociation, International Journal of Mass Spectrometry 174 (1998) 1-9.

[105] O. Meroueh, W.L. Hase, Energy transfer pathways in the collisional activation of peptides, International Journal of Mass Spectrometry 201 (2000) 233-244.

[106] J.P. Wang, S.O. Meroueh, Y.F. Wang, W.L. Hase, Efficiency of energy transfer in protonated diglycine and dialanine SID - Effects of collision angle, peptide ion size, and intramolecular potential, International Journal of Mass Spectrometry 230 (2003) 57-64.

[107] A. Rahaman, W.L. Hase, K. Song, J. Wang, O. Meroueh, Chemical Dynamics Simulations of Energy Transfer and Unimolecular Decomposition in Collision-Induced Dissociation (CID) and Surface-Induced Dissociation (SID), in: J. Laskin, C. Lifshitz, (Eds.), Principles of Mass Spectrometry Applied to Biomolecules, John Wiley \& Sons., Inc., Hoboken, NJ, 2006.

[108] G.L. Barnes, W.L. Hase, Energy Transfer, Unfolding, and Fragmentation Dynamics in Collisions of N-Protonated Octaglycine with an H-SAM Surface, Journal of the American Chemical Society 131 (2009) 17185-17193.

[109] L. Yang, O.A. Mazyar, U. Lourderaj, J.P. Wang, M.T. Rodgers, E. Martinez-Nunez, S.V. Addepalli, W.L. Hase, Chemical dynamics simulations of energy transfer in collisions of protonated peptide-ions with a perfluorinated alkylthiol self-assembled monolayer surface, Journal of Physical Chemistry C 112 (2008) 9377-9386.

[110] J. Laskin, T.H. Bailey, E.V. Denisov, J.H. Futrell, On the relative stability of singly protonated des-Arg ${ }^{1-}$ and des-Arg ${ }^{9}$-bradykinins, Journal of Physical Chemistry A 106 (2002) 9832-9836.

[111] J. Laskin, J.H. Futrell, On the efficiency of energy transfer in collisional activation of small peptides, Journal of Chemical Physics 116 (2002) 4302-4310.

[112] K. Vekey, A. Somogyi, V.H. Wysocki, INTERNAL ENERGY-DISTRIBUTION OF BENZENE MOLECULAR-IONS IN SURFACE-INDUCED DISSOCIATION, Journal of Mass Spectrometry 30 (1995) 212-217.

[113] S.O. Meroueh, Y.F. Wang, W.L. Hase, Direct dynamics Simulations of collision- and surfaceinduced dissociation of N-protonated glycine. Shattering fragmentation, Journal of Physical Chemistry A 106 (2002) 9983-9992. 
[114] K. Park, B. Deb, K. Song, W.L. Hase, Importance of Shattering Fragmentation in the SurfaceInduced Dissociation of Protonated Octaglycine, Journal of the American Society for Mass Spectrometry 20 (2009) 939-948.

[115] J. Laskin, J.H. Futrell, Surface-induced dissociation of peptide ions: Kinetics and dynamics, Journal of the American Society for Mass Spectrometry 14 (2003) 1340-1347.

[116] J. Laskin, K.M. Beck, J.J. Hache, J.H. Futrell, Surface-induced dissociation of ions produced by matrix-assisted laser desorption/ionization in a Fourier transform ion cyclotron resonance mass spectrometer, Analytical Chemistry 76 (2004) 351-356.

[117] F.M. Fernandez, V.H. Wysocki, J.H. Futrell, J. Laskin, Protein identification via surface-induced dissociation in an FT-ICR mass spectrometer and a patchwork sequencing approach, Journal of the American Society for Mass Spectrometry 17 (2006) 700-709.

[118] J.L. Jones, A.R. Dongre, A. Somogyi, V.H. Wysocki, Sequence dependence of peptide fragmentation efficiency curves determined by electrospray-ionization surface-induced dissociation mass-spectrometry, Journal of the American Chemical Society 116 (1994) 83688369.

[119] G. Tsaprailis, H. Nair, A. Somogyi, V.H. Wysocki, W.Q. Zhong, J.H. Futrell, S.G. Summerfield, S.J. Gaskell, Influence of secondary structure on the fragmentation of protonated peptides, Journal of the American Chemical Society 121 (1999) 5142-5154.

[120] H. Nair, V.H. Wysocki, Are peptides without basic residues protonated primarily at the amino terminus?, International Journal of Mass Spectrometry 174 (1998) 95-100.

[121] V.H. Wysocki, G. Tsaprailis, L.L. Smith, L.A. Breci, Special feature: Commentary - Mobile and localized protons: a framework for understanding peptide dissociation, Journal of Mass Spectrometry 35 (2000) 1399-1406.

[122] C.G. Gu, G. Tsaprailis, L. Breci, V.H. Wysocki, Selective gas-phase cleavage at the peptide bond terminal to aspartic acid in fixed-charge derivatives of asp-containing peptides, Analytical Chemistry 72 (2000) 5804-5813.

[123] G. Tsaprailis, A. Somogyi, E.N. Nikolaev, V.H. Wysocki, Refining the model for selective cleavage at acidic residues in arginine-containing protonated peptides, International Journal of Mass Spectrometry 195 (2000) 467-479.

[124] Y.Y. Huang, V.H. Wysocki, D.L. Tabb, J.R. Yates, The influence of histidine on cleavage Cterminal to acidic residues in doubly protonated tryptic peptides, International Journal of Mass Spectrometry 219 (2002) 233-244.

[125] J. Laskin, T.H. Bailey, J.H. Futrell, Mechanisms of peptide fragmentation from time- and energyresolved surface-induced dissociation studies: Dissociation of angiotensin analogs, International Journal of Mass Spectrometry 249 (2006) 462-472.

[126] J.M. Spraggins, J.A. Lloyd, M.V. Johnston, J. Laskin, D.P. Ridge, Fragmentation mechanisms of oxidized peptides elucidated by SID, RRKM modeling, and molecular dynamics, Journal of the American Society for Mass Spectrometry 20 (2009) 1579-1592.

[127] J. Laskin, Z.B. Yang, T. Song, C. Lam, I.K. Chu, Effect of the basic residue on the energetics, dynamics, and mechanisms of gas-phase fragmentation of protonated peptides, Journal of the American Chemical Society 132 (2010) 16006-16016.

[128] T.H. Bailey, J. Laskin, J.H. Futrell, Energetics of selective cleavage at acidic residues studied by time- and energy-resolved surface-induced dissociation in FT-ICR MS, International Journal of Mass Spectrometry 222 (2003) 313-327.

[129] J. Laskin, T.H. Bailey, J.H. Futrell, Fragmentation energetics for angiotensin II and its analogs from time-and energy-resolved surface-induced dissociation studies, International Journal of Mass Spectrometry 234 (2004) 89-99.

[130] J. Laskin, Energy and entropy effects in the gas phase dissociation of peptides and proteins, in: J. Laskin, C. Lifshitz, (Eds.), Principles of Mass Spectrometry Applied to Biomolecules, John Wiley \& Sons., Inc., Hoboken, NJ, 2006. 
[131] J. Laskin, Energetics and dynamics of fragmentation of protonated leucine enkephalin from timeand energy-resolved surface-induced dissociation studies, Journal of Physical Chemistry A 110 (2006) 8554-8562.

[132] J. Laskin, M. Byrd, J. Futrell, Internal energy distributions resulting from sustained off-resonance excitation in ftms. I. Fragmentation of the bromobenzene radical cation, International Journal of Mass Spectrometry 195 (2000) 285-302.

[133] J. Laskin, J. Futrell, Internal energy distributions resulting from sustained off-resonance excitation in fourier transform ion cyclotron resonance mass spectrometry. Ii. Fragmentation of the 1-bromonaphthalene radical cation, Journal of Physical Chemistry A 104 (2000) 5484-5494.

[134] H. Lioe, J. Laskin, G.E. Reid, R.A.J. O'Hair, Energetics and dynamics of the fragmentation reactions of protonated peptides containing methionine sulfoxide or aspartic acid via energy- and time-resolved surface induced dissociation, Journal of Physical Chemistry A 111 (2007) 1058010588.

[135] I.K. Chu, J. Laskin, Review formation of peptide radical ions through dissociative electron transfer in ternary metal-ligand-peptide complexes, European Journal of Mass Spectrometry 17 (2011) 543-556.

[136] J. Laskin, Z. Yang, I.K. Chu, Energetics and dynamics of electron transfer and proton transfer in dissociation of metal ${ }^{\mathrm{III}}$ (salen)-peptide complexes in the gas phase, Journal of the American Chemical Society 130 (2008) 3218-3230.

[137] J. Laskin, J.H. Futrell, I.K. Chu, Is dissociation of peptide radical cations an ergodic process?, Journal of the American Chemical Society 129 (2007) 9598-+.

[138] Z.B. Yang, C. Lam, I.K. Chu, J. Laskin, The effect of the secondary structure on dissociation of peptide radical cations: Fragmentation of angiotensin III and its analogues, Journal of Physical Chemistry B 112 (2008) 12468-12478.

[139] J. Laskin, Z.B. Yang, C. Lam, I.K. Chu, Energy and entropy effects in dissociation of peptide radical anions, International Journal of Mass Spectrometry 316 (2012) 251-258.

[140] J.C. Jurchen, E.R. Williams, Origin of asymmetric charge partitioning in the dissociation of gasphase protein homodimers, Journal of the American Chemical Society 125 (2003) 2817-2826.

[141] C.M. Jones, R.L. Beardsley, A.S. Galhena, S. Dagan, G.L. Cheng, V.H. Wysocki, Symmetrical gas-phase dissociation of noncovalent protein complexes via surface collisions, Journal of the American Chemical Society 128 (2006) 15044-15045.

[142] A.E. Blackwell, E.D. Dodds, V. Bandarian, V.H. Wysocki, Revealing the Quaternary Structure of a Heterogeneous Noncovalent Protein Complex through Surface-Induced Dissociation, Analytical Chemistry 83 (2011) 2862-2865.

[143] E.D. Dodds, A.E. Blackwell, C.M. Jones, K.L. Holso, D.J. O'Brien, M.H.J. Cordes, V.H. Wysocki, Determinants of Gas-Phase Disassembly Behavior in Homodimeric Protein Complexes with Related Yet Divergent Structures, Analytical Chemistry 83 (2011) 3881-3889.

[144] M.W. Zhou, S. Dagan, V.H. Wysocki, Protein Subunits Released by Surface Collisions of Noncovalent Complexes: Nativelike Compact Structures Revealed by Ion Mobility Mass Spectrometry, Angewandte Chemie-International Edition 51 (2012) 4336-4339.

[145] M.W. Zhou, S. Dagan, V.H. Wysocki, Impact of charge state on gas-phase behaviors of noncovalent protein complexes in collision induced dissociation and surface induced dissociation, Analyst 138 (2013) 1353-1362.

[146] M.W. Zhou, C.M. Jones, V.H. Wysocki, Dissecting the Large Noncovalent Protein Complex GroEL with Surface-Induced Dissociation and Ion Mobility Mass Spectrometry, Analytical Chemistry 85 (2013) 8262-8267.

[147] A.K. Badu-Tawiah, J. Cyriac, R.G. Cooks, Reactions of Organic Ions at Ambient Surfaces in a Solvent-Free Environment, Journal of the American Society for Mass Spectrometry 23 (2012) 842-849.

[148] A.K. Badu-Tawiah, C.P. Wu, R.G. Cooks, Ambient Ion Soft Landing, Analytical Chemistry 83 (2011) 2648-2654. 
[149] J.W. Shen, C. Evans, N. Wade, R.G. Cooks, Ion-ion collisions leading to formation of C-C bonds at surfaces: An interfacial Kolbe reaction, Journal of the American Chemical Society 121 (1999) 9762-9763.

[150] J. Alvarez, J.H. Futrell, J. Laskin, Soft-landing of peptides onto self-assembled monolayer surfaces, Journal of Physical Chemistry A 110 (2006) 1678-1687.

[151] M.B.J. Wijesundara, Y. Ji, B. Ni, S.B. Sinnott, L. Hanley, Effect of polyatomic ion structure on thin-film growth: Experiments and molecular dynamics simulations, Journal of Applied Physics 88 (2000) 5004-5016.

[152] N. Wade, C. Evans, S.C. Jo, R.G. Cooks, Silylation of an OH-terminated self-assembled monolayer surface through low-energy collisions of ions: a novel route to synthesis and patterning of surfaces, Journal of Mass Spectrometry 37 (2002) 591-602.

[153] N. Wade, B. Gologan, A. Vincze, R.G. Cooks, D.M. Sullivan, M.L. Bruening, Esterification and ether formation at a hydroxyl-terminated self-assembled monolayer surface using low-energy collisions of polyatomic cations, Langmuir 18 (2002) 4799-4808.

[154] P. Wang, O. Hadjar, J. Laskin, Covalent immobilization of peptides on self-assembled monolayer surfaces using soft-landing of mass-selected ions, Journal of the American Chemical Society 129 (2007) 8682-8683.

[155] P. Wang, O. Hadjar, P.L. Gassman, J. Laskin, Reactive landing of peptide ions on self-assembled monolayer surfaces: an alternative approach for covalent immobilization of peptides on surfaces, Physical Chemistry Chemical Physics 10 (2008) 1512-1522.

[156] Q.C. Hu, J. Laskin, Reactive landing of dendrimer ions onto activated self-assembled monolayer surfaces, Journal of Physical Chemistry C (2014).

[157] S. Nagaoka, K. Ikemoto, K. Horiuchi, A. Nakajima, Soft- and Reactive-Landing of Cr(aniline)(2) Sandwich Complexes onto Self-Assembled Monolayers: Separation between Functional and Binding Sites, Journal of the American Chemical Society 133 (2011) 18719-18727.

[158] M. Volny, W.T. Elam, B.D. Ratner, F. Turecek, Preparative soft and reactive landing of gasphase ions on plasma-treated metal surfaces, Analytical Chemistry 77 (2005) 4846-4853.

[159] G.E. Johnson, J. Laskin, Preparation of Surface Organometallic Catalysts by Gas-Phase Ligand Stripping and Reactive Landing of Mass-Selected Ions, Chemistry - A European Journal 16 (2010) 14433-14438.

[160] M. Mitsui, S. Nagaoka, T. Matsumoto, A. Nakajima, Soft-landing isolation of vanadium-benzene sandwich clusters on a room-temperature substrate using n-alkanethiolate self-assembled monolayer matrixes, Journal of Physical Chemistry B 110 (2006) 2968-2971.

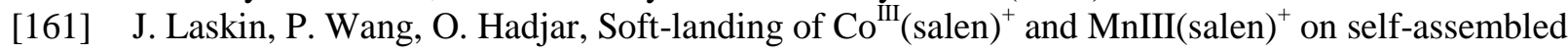
monolayer surfaces, Journal of Physical Chemistry C 114 (2010) 5305-5311.

[162] N. Thontasen, G. Levita, N. Malinowski, Z. Deng, S. Rauschenbach, K. Kern, Grafting Crown Ether Alkali Host-Guest Complexes at Surfaces by Electrospray Ion Beam Deposition, Journal of Physical Chemistry C 114 (2010) 17768-17772.

[163] L. Hanley, H.J. Lim, D.G. Schultz, S.B. Wainhaus, P. deSainteClaire, W.L. Hase, Surface energy transfer by low energy polyatomic ion collisions, Nuclear Instruments \& Methods in Physics Research Section B-Beam Interactions with Materials and Atoms 125 (1997) 218-222.

[164] S.C. Nanita, Z. Takats, R.G. Cooks, S. Myung, D.E. Clemmer, Chiral enrichment of serine via formation, dissociation, and soft-landing of octameric cluster ions, Journal of the American Society for Mass Spectrometry 15 (2004) 1360-1365.

[165] B. Wang, B. Yoon, M. Konig, Y. Fukamori, F. Esch, U. Heiz, U. Landman, Size-Selected Monodisperse Nanoclusters on Supported Graphene: Bonding, Isomerism, and Mobility, Nano Letters 12 (2012) 5907-5912.

[166] B. Yoon, H. Hakkinen, U. Landman, A.S. Worz, J.M. Antonietti, S. Abbet, K. Judai, U. Heiz, Charging effects on bonding and catalyzed oxidation of $\mathrm{CO}$ on $\mathrm{Au}-8$ clusters on $\mathrm{MgO}$, Science 307 (2005) 403-407. 
[167] G. Kwon, G.A. Ferguson, C.J. Heard, E.C. Tyo, C.R. Yin, J. DeBartolo, S. Seifert, R.E. Winans, A.J. Kropf, J. Greeley, R.L. Johnston, L.A. Curtiss, M.J. Pellin, S. Vajda, Size-Dependent Subnanometer Pd Cluster (Pd-4, Pd-6, and Pd-17) Water Oxidation Electrocatalysis, Acs Nano 7 (2013) 5808-5817.

[168] Y. Lei, F. Mehmood, S. Lee, J. Greeley, B. Lee, S. Seifert, R.E. Winans, J.W. Elam, R.J. Meyer, P.C. Redfern, D. Teschner, R. Schlogl, M.J. Pellin, L.A. Curtiss, S. Vajda, Increased Silver Activity for Direct Propylene Epoxidation via Subnanometer Size Effects, Science 328 (2010) 224-228.

[169] B. Gologan, Z. Takats, J. Alvarez, J.M. Wiseman, N. Talaty, Z. Ouyang, R.G. Cooks, Ion softlanding into liquids: Protein identification, separation, and purification with retention of biological activity, Journal of the American Society for Mass Spectrometry 15 (2004) 1874-1884.

[170] P. Wang, J. Laskin, Helical peptide arrays on self-assembled monolayer surfaces through soft and reactive landing of mass-selected ions, Angewandte Chemie-International Edition 47 (2008) 6678-6680.

[171] B.B. Feng, D.S. Wunschel, C.D. Masselon, L. Pasa-Tolic, R.D. Smith, Retrieval of DNA using soft-landing after mass analysis by ESI-FTICR for enzymatic manipulation, Journal of the American Chemical Society 121 (1999) 8961-8962.

[172] G. Siuzdak, B. Bothner, M. Yeager, C. Brugidou, C.M. Fauquet, K. Hoey, C.M. Chang, Mass spectrometry and viral analysis, Chemistry \& Biology 3 (1996) 45-48.

[173] D. Loffler, S.S. Jester, P. Weis, A. Bottcher, M.M. Kappes, $C_{n}$ films ( $n=50,52,54,56$, and 58) on graphite: Cage size dependent electronic properties, Journal of Chemical Physics 124 (2006).

[174] D. Loffler, S. Ulas, S.S. Jester, P. Weis, A. Bottcher, M.M. Kappes, Properties of non-IPR fullerene films versus size of the building blocks, Physical Chemistry Chemical Physics 12 (2010) 10671-10684.

[175] S. Ulas, D. Strelnikov, P. Weis, A. Bottcher, M.M. Kappes, Incorporating C-2 into C-60 films, Journal of Chemical Physics 136 (2012).

[176] G.R. Blacken, M. Volny, T. Vaisar, M. Sadılek, F. Turecek, In Situ Enrichment of Phosphopeptides on MALDI Plates Functionalized by Reactive Landing of Zirconium(IV)-nPropoxide Ions, Analytical Chemistry 79 (2007) 5449-5456.

[177] W. Hoffmann, G. Verbeck, Toward a Reusable Surface-Enhanced Raman Spectroscopy (SERS) Substrate by Soft-Landing Ion Mobility, Applied Spectroscopy 67 (2013) 656-660.

[178] A.A. Tsekouras, M.J. Iedema, J.P. Cowin, Soft-landed ion diffusion studies on vapor-deposited hydrocarbon films, Journal of Chemical Physics 111 (1999) 2222-2234.

[179] W.P. Peng, G.E. Johnson, I.C. Fortmeyer, P. Wang, O. Hadjar, R.G. Cooks, J. Laskin, Redox chemistry in thin layers of organometallic complexes prepared using ion soft landing, Physical Chemistry Chemical Physics 13 (2011) 267-275.

[180] N. Hauptmann, C. Hamann, H. Tang, R. Berndt, Switching and charging of a ruthenium dye on $\operatorname{Ag}(111)$, Physical Chemistry Chemical Physics 15 (2013) 10326-10330.

[181] Q.C. Hu, P. Wang, J. Laskin, Effect of the surface on the secondary structure of soft landed peptide ions, Physical Chemistry Chemical Physics 12 (2010) 12802-12810.

[182] S. Kahle, Z.T. Deng, N. Malinowski, C. Tonnoir, A. Forment-Aliaga, N. Thontasen, G. Rinke, D. Le, V. Turkowski, T.S. Rahman, S. Rauschenbach, M. Ternes, K. Kern, The Quantum Magnetism of Individual Manganese-12-Acetate Molecular Magnets Anchored at Surfaces, Nano Letters 12 (2012) 518-521.

[183] O. Hadjar, J.H. Futrell, J. Laskin, First observation of charge reduction and desorption kinetics of multiply protonated peptides soft landed onto self-assembled monolayer surfaces, Journal of Physical Chemistry C 111 (2007) 18220-18225.

[184] G.L. Barnes, K. Young, L. Yang, W.L. Hase, Fragmentation and reactivity in collisions of protonated diglycine with chemically modified perfluorinated alkylthiolate-self-assembled monolayer surfaces, Journal of Chemical Physics 134 (2011). 
[185] J. Laskin, P. Wang, O. Hadjar, J.H. Futrell, J. Alvarez, Z.G. Cooks, Charge retention by peptide ions soft-landed onto self-assembled monolayer surfaces, International Journal of Mass Spectrometry 265 (2007) 237-243.

[186] G.E. Johnson, T. Priest, J. Laskin, Charge retention by gold clusters on surfaces prepared using soft landing of mass selected ions, ACS Nano 6 (2012) 573-582.

[187] G.E. Johnson, T. Priest, J. Laskin, Coverage-dependent charge reduction of cationic gold clusters on surfaces prepared using soft landing of mass-selected ions, Journal of Physical Chemistry C 116 (2012) 24977-24986. 


\section{Figures.}

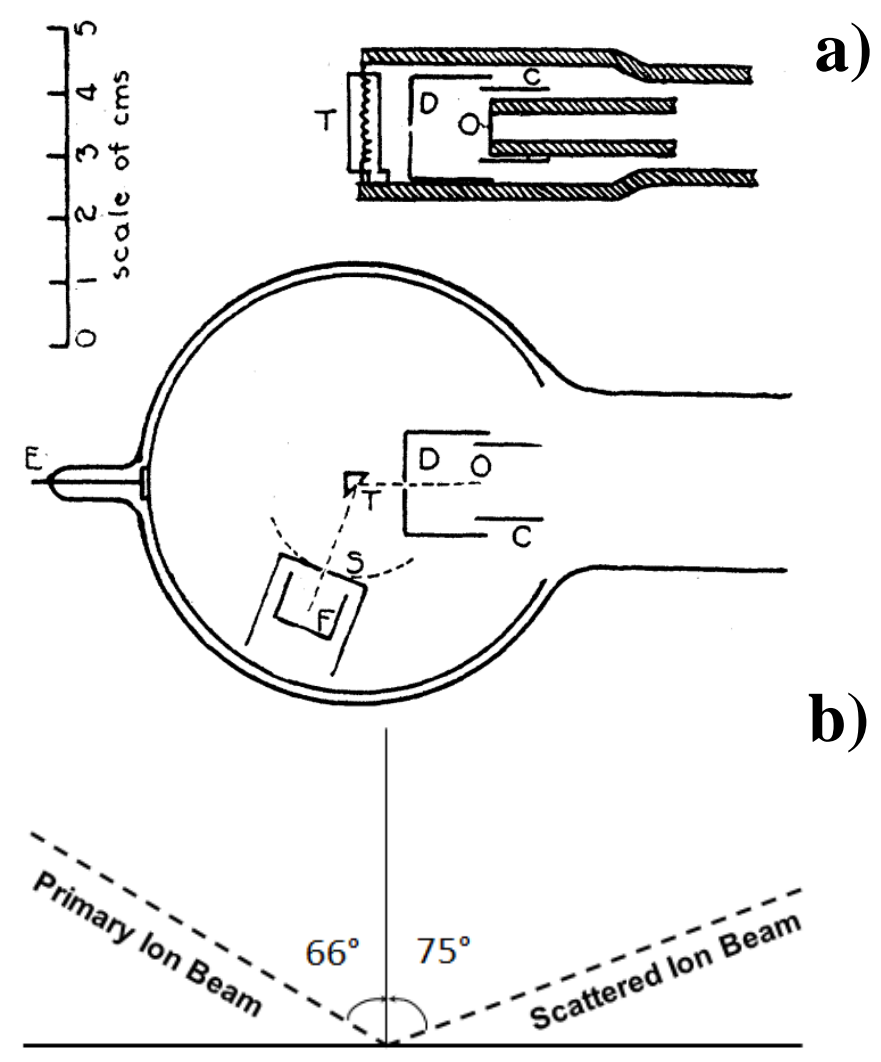

Figure 1. a) Schematic drawing of the first scattering apparatus. b) Optimal scattering geometry. The angles are measured relative to the surface normal. Reproduced with permission from [30]. 


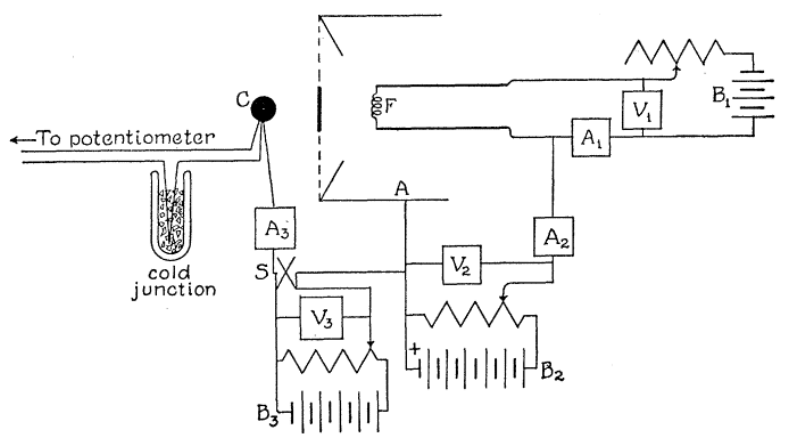

Figure 2. Schematic drawing of the first soft-landing apparatus. Reproduced with permission from [31].

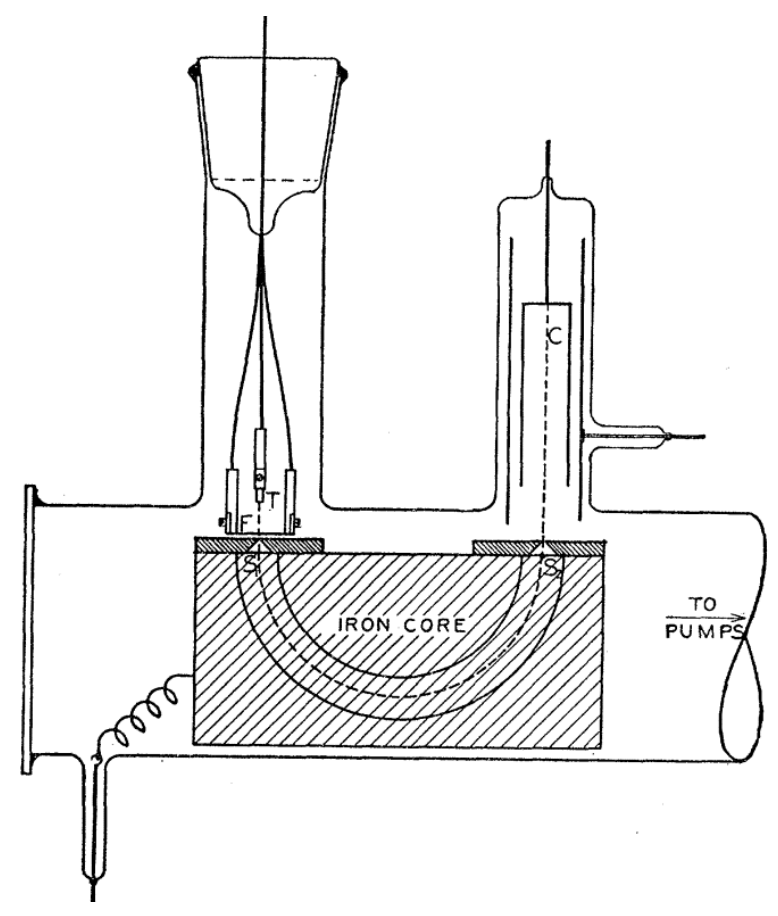

Figure 3. Schematic drawing of the first SIMS instrument. Reproduced with permission from [32]. 


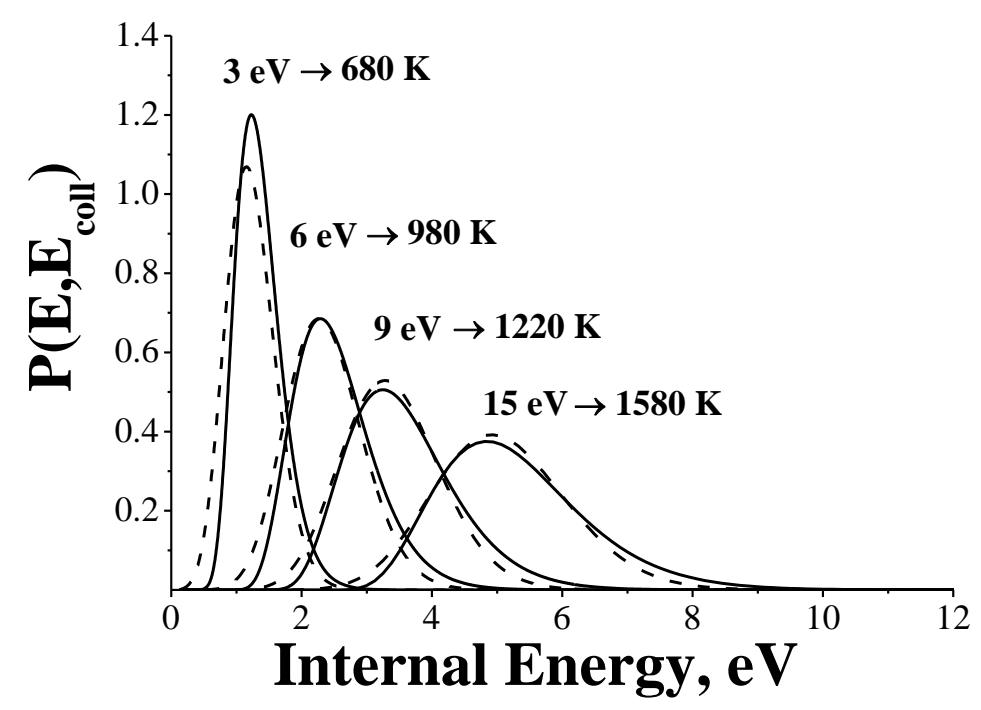

Figure 4. Comparison of internal energy distributions following collisions of protonated dialanine with an FSAM surface at 3, 6, 9, and $15 \mathrm{eV}$ and thermal distributions calculated for 680, 980, 1220, and $1580 \mathrm{~K}$. Reproduced with permission from [102].

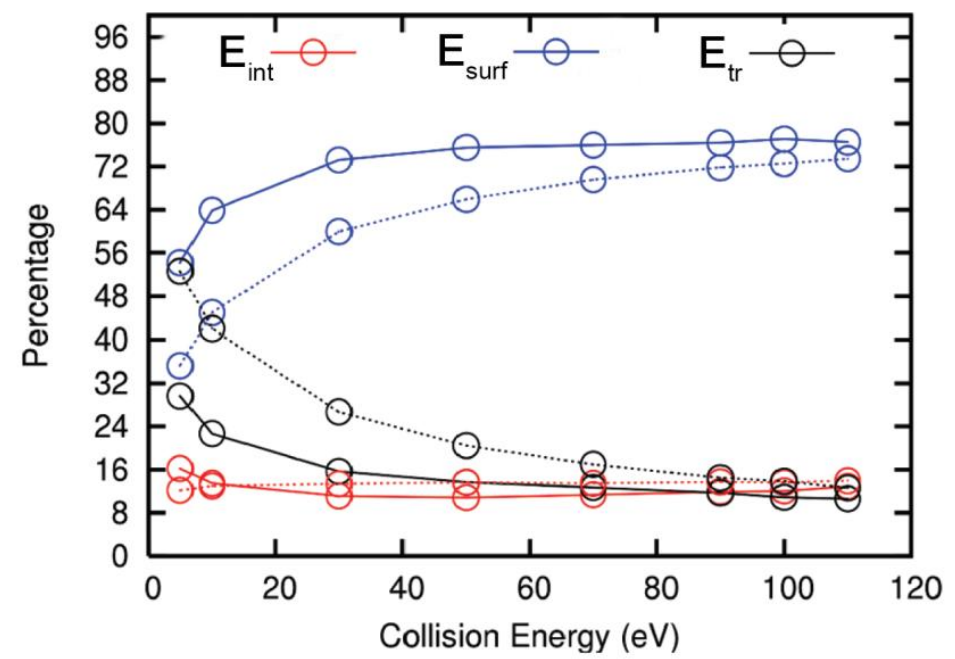

Figure 5. The percentage of energy transfer into the internal excitation of the precursor ion $\left(\mathrm{E}_{\mathrm{int}}\right)$, the surface $\left(E_{\text {surf }}\right)$, and translation of the scattered ions $\left(E_{t r}\right)$ as a function of the initial kinetic energy of $\left[\mathrm{Gly}_{8}+\mathrm{H}\right]^{+}$collisions with $\mathrm{HSAM}$ at $0^{\circ}$ (solid lines) and $45^{\circ}$ (dashed lines). Reproduced with permission from [108]. 


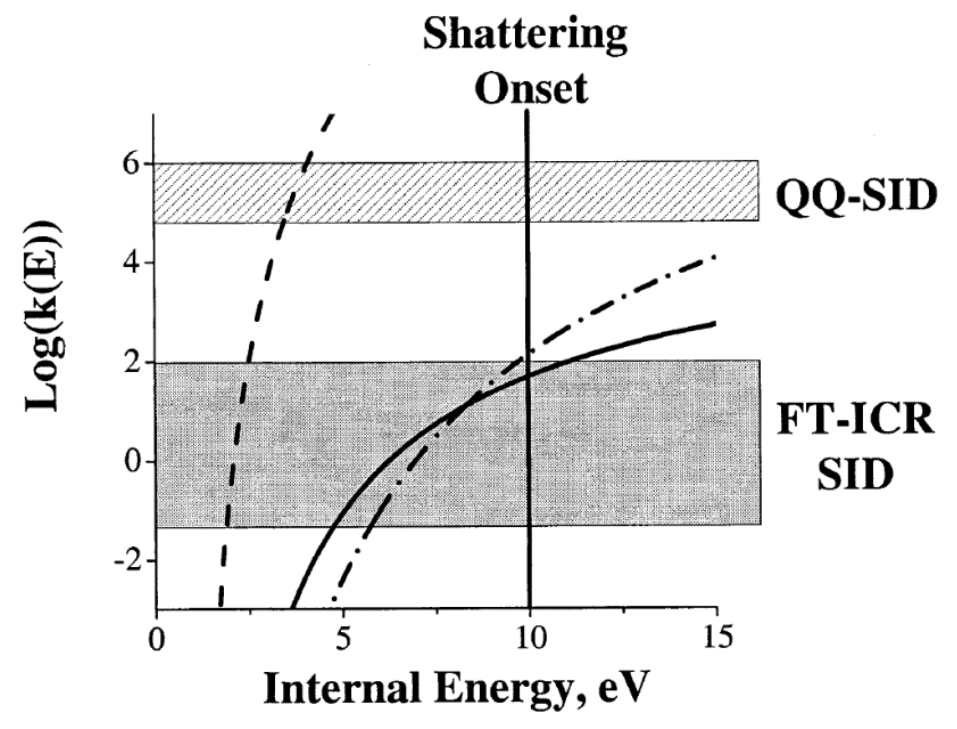

Figure 6. Semilogarithmic plot of the microcanonical rate-energy dependencies for dissociation of singly protonated pentaalanine (dashed line), des-Arg1-bradykinin (solid line), and Fibrinopeptide A (dash-dot line). The vertical solid line shows the shattering onset. The hatched area corresponds to the experimental time window of the QQ-SID setup, and the shadowed area depicts the observation window in the FT-ICR SID experiment. Reproduced with permission from [115]. 
(a) CID

-1mer • $2 \mathrm{mer} \cdot 3 \mathrm{mer} \cdot 4 \mathrm{mer} \cdot 5 \mathrm{mer} \cdot 6 \mathrm{mer} \cdot 7 \mathrm{mer}$

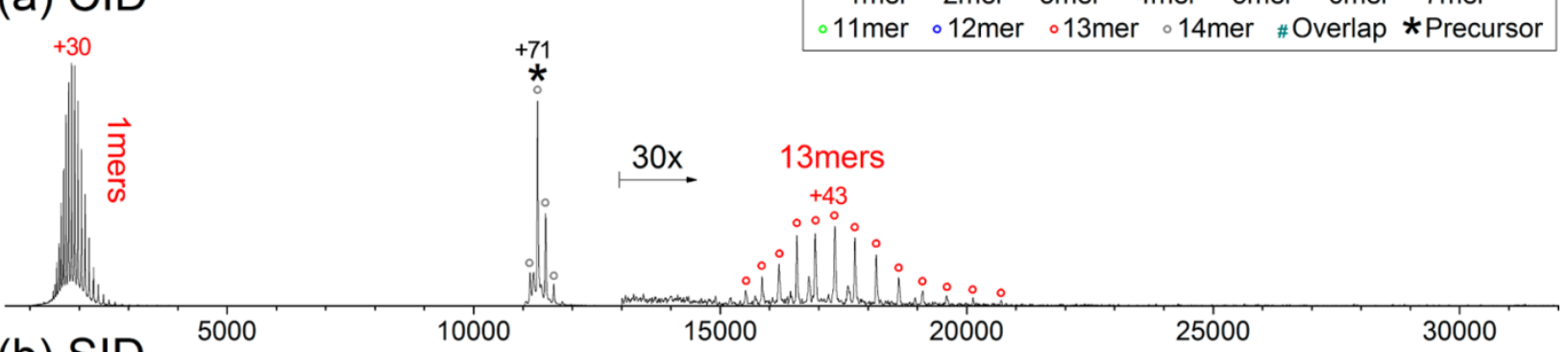

(b) SID
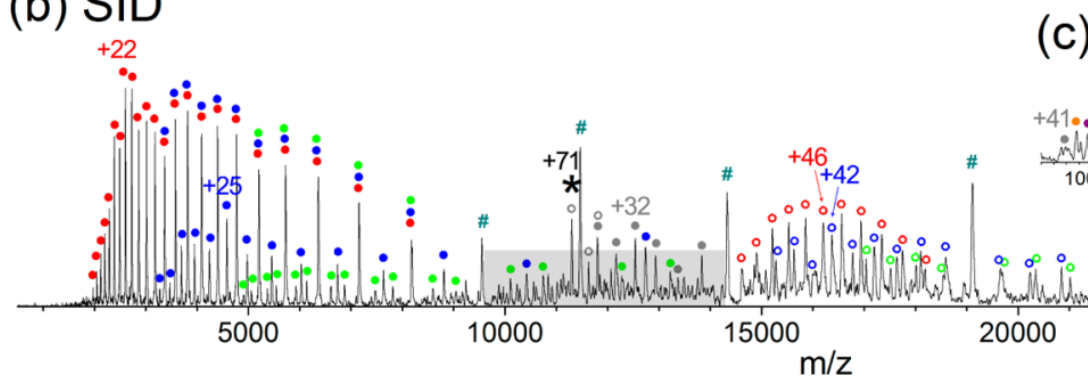

\section{(c)}

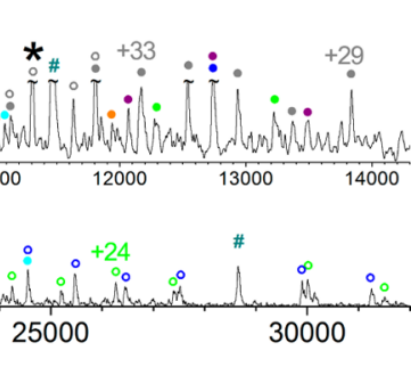

Figure 7. (a) CID of GroEL tetradecamer +71 at an acceleration voltage of $160 \mathrm{~V}$. (b) SID of GroEL tetradecamer +71 at an acceleration voltage of $180 \mathrm{~V}$. Major peaks are labeled following the legend (inset, top). (c) The inset spectrum is a zoom-in view of the region shaded in the middle of the full SID spectrum with more assignments for the peaks at low abundances. Charge states of several peaks discussed in the text are selectively labeled with the corresponding dot colors depicted in the legend. Ejection of highly charged monomers is the predominant dissociation pathway in CID. In contrast, SID shows extensive dissociation into a variety of products. Reproduced with permission from [146]. 

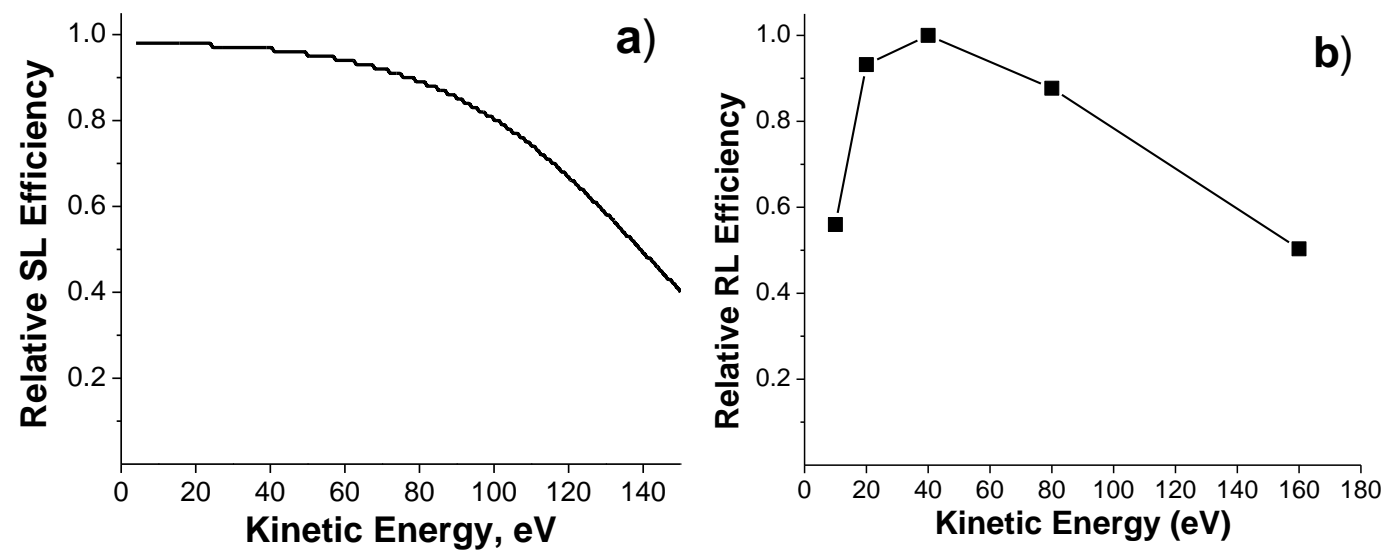

Figure 8. (a) Relative soft landing (SL) and (b) reactive landing efficiencies as a function of the projectile ion's kinetic energy. The relative soft landing efficiency was calculated from FT-ICR SIMS data obtained for the doubly protonated bradykinin deposition onto an FSAM surface at different kinetic energies.[155] The relative reactive landing efficiency was obtained for deposition of $2 \times 10^{12}$ doubly protonated c(-RGDfK-) peptide onto an NHS-SAM surface. Reproduced with permission from $[150,155]$. 
a

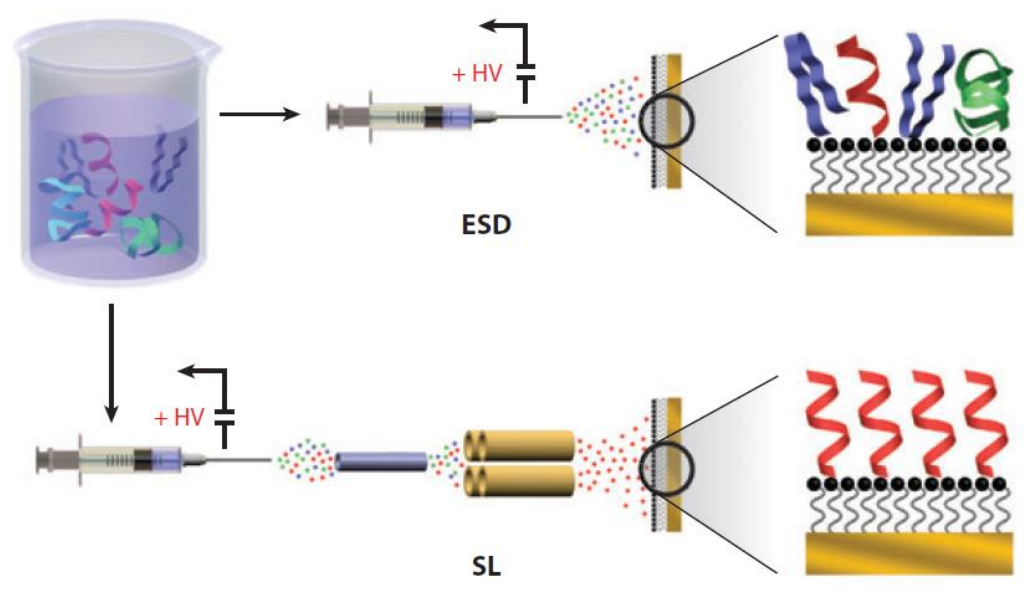

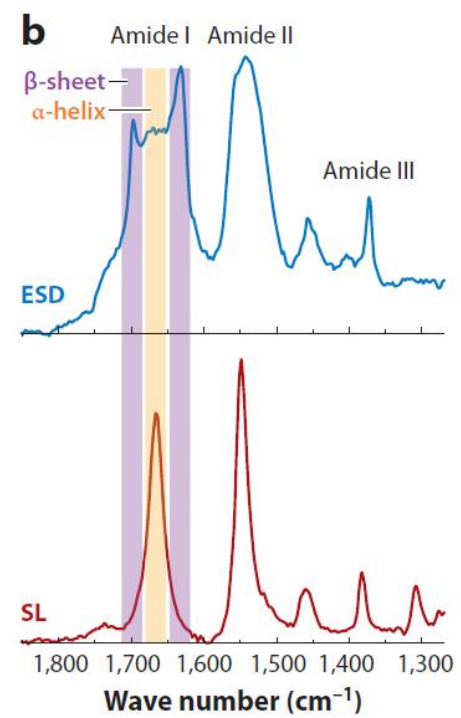

Figure 9. (a) Schematic drawing of (top) electrospray deposition (ESD) and (bottom) soft landing (SL) of peptide ions on self-assembled monolayer (SAM) surfaces. ESD of AcA15K from solution results in the formation of a peptide layer dominated by the $\beta$-sheet structure, and a stable $\alpha$-helical peptide layer on SAM surfaces is formed by SL. (b) IRRAS spectra of an AcA15K layer on the hydrocarbon SAM surface prepared by (top) ESD and (bottom) SL. The purple areas correspond to characteristic absorption of the $\beta$-sheet conformation, and the position of the $\alpha$-helical band is highlighted in gold. Reproduced with permission from [171] and [10]. 

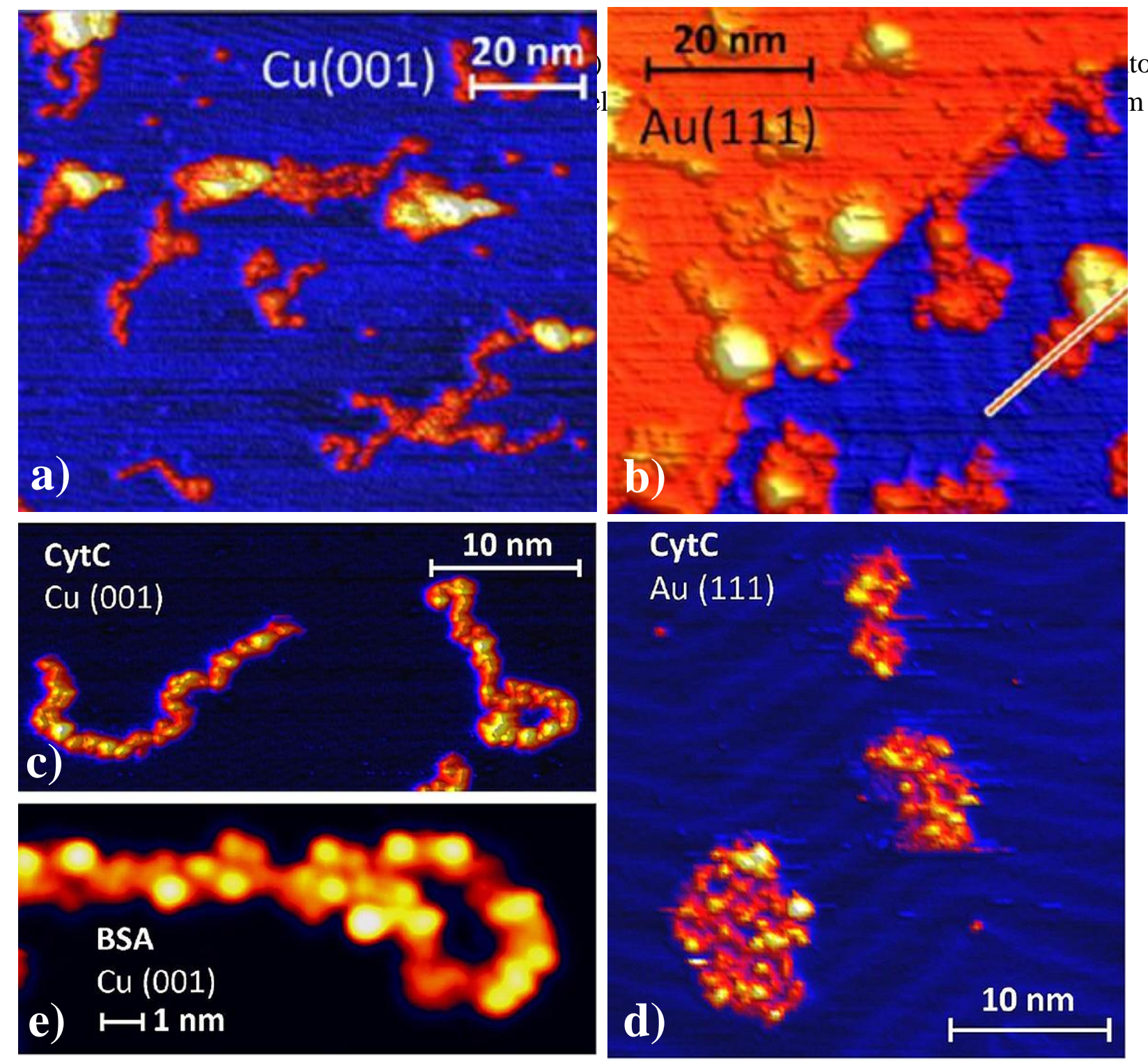


\section{References}

[1] J.J. Thomson, Rays of positive electricity and their application to chemical analyses, Longmans, Green and Co., London, New York, 1913.

[2] V. Franchetti, B.H. Solka, W.E. Baitinger, J.W. Amy, R.G. Cooks, Soft Landing of lons as a Means of Surface Modification, International Journal of Mass Spectrometry and Ion Processes, 23 (1977) 29-35.

[3] M.D.A. Mabud, M.J. Dekrey, R.G. Cooks, Surface-induced dissociation of molecular ions, International Journal of Mass Spectrometry and Ion Processes, 67 (1985) 285-294.

[4] A.R. Dongre, A. Somogyi, V.H. Wysocki, Surface-induced dissociation: An effective tool to probe structure, energetics and fragmentation mechanisms of protonated peptides, Journal of Mass Spectrometry, 31 (1996) 339-350.

[5] A.R. Dongre, J.L. Jones, A. Somogyi, V.H. Wysocki, Influence of peptide composition, gas-phase basicity, and chemical modification on fragmentation efficiency: Evidence for the mobile proton model, Journal of the American Chemical Society, 118 (1996) 8365-8374.

[6] V. Grill, J. Shen, C. Evans, R.G. Cooks, Collisions of ions with surfaces at chemically relevant energies: Instrumentation and phenomena, Review of Scientific Instruments, 72 (2001) 3149-3179.

[7] B. Gologan, J.M. Wiseman, R.G. Cooks, lon Soft Landing: Instrumentation, Phenomena, and Applications, in: J. Laskin, C. Lifshitz (Eds.) Principles of Mass Spectrometry Applied to Biomolecules, John Wiley \& Sons., Inc., Hoboken, NJ, 2006.

[8] J. Cyriac, T. Pradeep, H. Kang, R. Souda, R.G. Cooks, Low-Energy lonic Collisions at Molecular Solids, Chemical Reviews, 112 (2012) 5356-5411.

[9] J. Laskin, P. Wang, O. Hadjar, Soft-landing of peptide ions onto self-assembled monolayer surfaces: an overview, Physical Chemistry Chemical Physics, 10 (2008) 1079-1090.

[10] G.E. Johnson, Q.C. Hu, J. Laskin, Soft Landing of Complex Molecules on Surfaces, Annual Review of Analytical Chemistry, 4 (2011) 83-104.

[11] G. Verbeck, W. Hoffmann, B. Walton, Soft-landing preparative mass spectrometry, Analyst, 137 (2012) 4393-4407.

[12] V.H. Wysocki, K.E. Joyce, C.M. Jones, R.L. Beardsley, Surface-induced dissociation of small molecules, peptides, and non-covalent protein complexes, Journal of the American Society for Mass Spectrometry, 19 (2008) 190-208.

[13] R.G. Cooks, T. Ast, A. Mabud, Collisions of polyatomic ions with surfaces, International Journal of Mass Spectrometry, 100 (1990) 209-265.

[14] R.G. Cooks, T. Ast, T. Pradeep, V. Wysocki, Reactions of ions with organic surfaces, Accounts of Chemical Research, 27 (1994) 316-323.

[15] P. Wang, J. Laskin, Surface Modification Using Reactive Landing of Mass-Selected lons, in: R. Hellborg, H.J. Whitlow, Y. Zhang (Eds.) Ion Beams in Nanoscience and Technology, Springer, London, New York, 2009.

[16] T. Raz, R.D. Levine, On the shattering of clusters by surface impact heating, Journal of Chemical Physics, 105 (1996) 8097-8102.

[17] W. Christen, U. Even, T. Raz, R.D. Levine, Collisional energy loss in cluster surface impact:

Experimental, model, and simulation studies of some relevant factors, Journal of Chemical Physics, 108 (1998) 10262-10273.

[18] W. Christen, U. Even, Cluster impact chemistry, Journal of Physical Chemistry A, 102 (1998) 94209426.

[19] R.D. Beck, C. Warth, K. May, M.M. Kappes, Surface impact induced shattering of $C_{60}$. Detection of small $C_{m}$ fragments by negative surface ionization, Chemical Physics Letters, 257 (1996) 557-562.

[20] O. Meroueh, W.L. Hase, Effect of surface stiffness on the efficiency of surface-induced dissociation, Physical Chemistry Chemical Physics, 3 (2001) 2306-2314. 
[21] J. Laskin, T.H. Bailey, J.H. Futrell, Shattering of peptide ions on self-assembled monolayer surfaces, Journal of the American Chemical Society, 125 (2003) 1625-1632.

[22] T. Ast, D.E. Riederer, S.A. Miller, M. Morris, R.G. Cooks, Collisions of fluorocarbon ions at solidsurfaces - electronic excitation, surface-induced dissociation and chemical sputtering, Organic Mass Spectrometry, 28 (1993) 1021-1033.

[23] C. Xirouchaki, R.E. Palmer, Pinning and implantation of size-selected metal clusters: a topical review, Vacuum, 66 (2002) 167-173.

[24] N. Winograd, B.J. Garrison, Biological Cluster Mass Spectrometry, Annual Review of Physical Chemistry, 61 (2010) 305-322.

[25] R.J. Day, S.E. Unger, R.G. Cooks, Molecular secondary ion mass-spectrometry, Analytical Chemistry, 52 (1980) A557-\&.

[26] A. Benninghoven, Chemical-analysis of inorganic and organic-surfaces and thin-films by static timeof-flight secondary-ion mass-spectrometry (TOF-SIMS), Angew. Chem.-Int. Edit. Engl., 33 (1994) 10231043.

[27] L. Hanley, S.B. Sinnott, The growth and modification of materials via ion-surface processing, Surface Science, 500 (2002) 500-522.

[28] D.C. Jacobs, Reactive collisions of hyperthermal energy molecular ions with solid surfaces, Annual Review of Physical Chemistry, 53 (2002) 379-407.

[29] B. Gologan, J.R. Green, J. Alvarez, J. Laskin, R.G. Cooks, lon/surface reactions and ion soft-landing, Physical Chemistry Chemical Physics, 7 (2005) 1490-1500.

[30] R.W. Gurney, The scattering of positive ions from a platinum surface, Phys. Rev., 32 (1928) 04670477.

[31] C.C. Van Voorhis, K.T. Compton, Accommodation coefficients of positive ions of argon, neon and helium, Phys. Rev., 37 (1931) 1596-1610.

[32] K.S. Woodcock, The emission of negative ions under the bombardment of positive ions, Phys. Rev., 38 (1931) 1696-1703.

[33] R.E. Honig, The development of secondary ion mass-spectrometry (SIMS) - A retrospective, International Journal of Mass Spectrometry and Ion Processes, 66 (1985) 31-54.

[34] J.H. Beynon, A.E. Fontaine, G.R. Lester, An anomalous metastable peak in mass spectrum of methanol, Chem. Commun., (1968) 265-\&.

[35] R.G. Cooks, Metastable ions, Elsevier Scientific Pub. Co., 1973.

[36] C. Lifshitz, M. Shapiro, Sternber.R, Isotope effects on metastable transitions .4. Isotopic methanols, Isr. J. Chem., 7 (1969) 391-\&.

[37] R.G. Cooks, T. Ast, J.H. Beynon, Anomalous metastable peaks, International Journal of Mass Spectrometry and lon Processes, 16 (1975) 348-352.

[38] R.G. Cooks, D.T. Terwilliger, T. Ast, J.H. Beynon, T. Keough, Surface modified mass-spectrometry, Journal of the American Chemical Society, 97 (1975) 1583-1585.

[39] S.A. Miller, H. Luo, S.J. Pachuta, R.G. Cooks, Soft-landing of polyatomic ions at fluorinated selfassembled monolayer surfaces, Science, 275 (1997) 1447-1450.

[40] A. Bottcher, P. Weis, S.S. Jester, D. Loffler, A. Bihlmeier, W. Klopper, M.M. Kappes, Solid C 58 films, Physical Chemistry Chemical Physics, 7 (2005) 2816-2820.

[41] Z. Ouyang, Z. Takats, T.A. Blake, B. Gologan, A.J. Guymon, J.M. Wiseman, J.C. Oliver, V.J. Davisson, R.G. Cooks, Preparing protein microarrays by soft-landing of mass-selected ions, Science, 301 (2003) 1351-1354.

[42] J. Alvarez, R.G. Cooks, S.E. Barlow, D.J. Gaspar, J.H. Futrell, J. Laskin, Preparation and in situ characterization of surfaces using soft landing in a Fourier transform ion cyclotron resonance mass spectrometer, Analytical Chemistry, 77 (2005) 3452-3460. 
[43] M. Volny, W.T. Elam, A. Branca, B.D. Ratner, F. Turecek, Preparative soft and reactive landing of multiply charged protein ions on a plasma-treated metal surface, Analytical Chemistry, 77 (2005) 4890 4896.

[44] H.J. Rader, A. Rouhanipour, A.M. Talarico, V. Palermo, P. Samori, K. Mullen, Processing of giant graphene molecules by soft-landing mass spectrometry, Nature Materials, 5 (2006) 276-280.

[45] R.E. Palmer, S. Pratontep, H.G. Boyen, Nanostructured surfaces from size-selected clusters, Nature Materials, 2 (2003) 443-448.

[46] U. Heiz, F. Vanolli, L. Trento, W.D. Schneider, Chemical reactivity of size-selected supported clusters: An experimental setup, Review of Scientific Instruments, 68 (1997) 1986-1994.

[47] S. Vajda, M.J. Pellin, J.P. Greeley, C.L. Marshall, L.A. Curtiss, G.A. Ballentine, J.W. Elam, S. CatillonMucherie, P.C. Redfern, F. Mehmood, P. Zapol, Subnanometre platinum clusters as highly active and selective catalysts for the oxidative dehydrogenation of propane, Nature Materials, 8 (2009) 213-216. [48] G.E. Johnson, M. Lysonski, J. Laskin, In situ reactivity and TOF-SIMS analysis of surfaces prepared by soft and reactive landing of mass-selected ions, Analytical Chemistry, 82 (2010) 5718-5727.

[49] Z.X. Nie, G.T. Li, M.P. Goodwin, L. Gao, J. Cyriac, R.G. Cooks, In Situ SIMS Analysis and Reactions of Surfaces Prepared by Soft Landing of Mass-Selected Cations and Anions Using an Ion Trap Mass Spectrometer, Journal of the American Society for Mass Spectrometry, 20 (2009) 949-956.

[50] J. Cyriac, M. Wleklinski, G.T. Li, L. Gao, R.G. Cooks, In situ Raman spectroscopy of surfaces modified by ion soft landing, Analyst, 137 (2012) 1363-1369.

[51] M. Volny, A. Sengupta, C.B. Wilson, B.D. Swanson, E.J. Davis, F. Turecek, Surface-enhanced Raman spectroscopy of soft-landed polyatomic ions and molecules, Analytical Chemistry, 79 (2007) 4543-4551.

[52] Q.C. Hu, P. Wang, P.L. Gassman, J. Laskin, In situ studies of soft- and reactive landing of massselected ions using infrared reflection absorption spectroscopy, Analytical Chemistry, 81 (2009) 73027308.

[53] S. Nagaoka, T. Matsumoto, K. Ikemoto, M. Mitsui, A. Nakajima, Soft-landing isolation of multidecker V-2(benzene)(3) complexes in an organic monolayer matrix: An infrared spectroscopy and thermal desorption study, Journal of the American Chemical Society, 129 (2007) 1528-+.

[54] J.P. Cowin, A.A. Tsekouras, M.J. Iedema, K. Wu, G.B. Ellison, Immobility of protons in ice from 30 to 190 K, Nature, 398 (1999) 405-407.

[55] Z.T. Deng, N. Thontasen, N. Malinowski, G. Rinke, L. Harnau, S. Rauschenbach, K. Kern, A Close Look at Proteins: Submolecular Resolution of Two- and Three-Dimensionally Folded Cytochrome c at Surfaces, Nano Letters, 12 (2012) 2452-2458.

[56] N. Hauptmann, K. Scheil, T.G. Gopakumar, F.L. Otte, C. Schütt, R. Herges, R. Berndt, Surface Control of Alkyl Chain Conformations and 2D Chiral Amplification, Journal of the American Chemical Society, 135 (2013) 8814-8817.

[57] N. Bajales, S. Schmaus, T. Miyamashi, W. Wulfhekel, J. Wilhelm, M. Walz, M. Stendel, A. Bagrets, F. Evers, S. Ulas, B. Kern, A. Bottcher, M.M. Kappes, $\mathrm{C}_{58}$ on $\mathrm{Au}(111)$ : A scanning tunneling microscopy study, Journal of Chemical Physics, 138 (2013) 104703.

[58] S. Ulas, D. Loffler, P. Weis, A. Bottcher, M.M. Kappes, Desorption of $C_{60}$ upon thermal decomposition of cesium $C_{58}$ fullerides, Journal of Chemical Physics, 136 (2012) 114708.

[59] G.E. Johnson, C. Wang, T. Priest, J. Laskin, Monodisperse $\mathrm{Au}_{11}$ clusters prepared by soft landing of mass selected ions, Analytical Chemistry, 83 (2011) 8069-8072.

[60] J.L.P. Benesch, B.T. Ruotolo, D.A. Simmons, N.P. Barrera, N. Morgner, L. Wang, H.R. Saibil, C.V. Robinson, Separating and visualising protein assemblies by means of preparative mass spectrometry and microscopy, Journal of Structural Biology, 172 (2010) 161-168.

[61] M.E. Bier, J.W. Amy, R.G. Cooks, J.E.P. Syka, P. Ceja, G. Stafford, A tandem quadrupole massspectrometer for the study of surface-induced dissociation, International Journal of Mass Spectrometry and lon Processes, 77 (1987) 31-47. 
[62] V.H. Wysocki, J.M. Ding, J.L. Jones, J.H. Callahan, F.L. King, Surface-induced dissociation in tandem quadrupole mass spectrometers - a comparison of 3 designs, Journal of the American Society for Mass Spectrometry, 3 (1992) 27-32.

[63] Z. Ouyang, V. Grill, J. Alvarez, C.H. Doerge, L. Gianelli, P. Thomas, H.W. Rohrs, R.G. Cooks, A multiquadrupole tandem mass spectrometer for the study of ion/surface collision processes, Review of Scientific Instruments, 73 (2002) 2375-2391.

[64] M.E. Bier, J.C. Schwartz, K.L. Schey, R.G. Cooks, Tandem mass-spectrometry using an in-line ion surface collision device, International Journal of Mass Spectrometry and Ion Processes, 103 (1990) 1-19. [65] A.S. Galhena, S. Dagan, C.M. Jones, R.L. Beardsley, V.N. Wysocki, Surface-induced dissociation of peptides and protein complexes in a quadrupole/Time-of-Flight mass spectrometer, Analytical Chemistry, 80 (2008) 1425-1436.

[66] K.L. Schey, D.A. Durkin, K.R. Thornburg, Design and performance of an in-line surface-induced dissociation device in a 4-sector mass-spectrometer, Journal of the American Society for Mass Spectrometry, 6 (1995) 257-263.

[67] S.A. Lammert, R.G. Cooks, Surface-induced dissociation of molecular-ions in a quadrupole ion trap mass-spectrometer, Journal of the American Society for Mass Spectrometry, 2 (1991) 487-491.

[68] B.E. Winger, H.J. Laue, S.R. Horning, R.K. Julian, S.A. Lammert, D.E. Riederer, R.G. Cooks, Hybrid BEEQ tandem mass-spectrometer for the study of ion surface collision processes, Review of Scientific Instruments, 63 (1992) 5613-5625.

[69] K. Schey, R.G. Cooks, R. Grix, H. Wollnik, A tandem time-of-flight mass-spectrometer for surfaceinduced dissociation, International Journal of Mass Spectrometry and Ion Processes, 77 (1987) 49-61.

[70] L.L. Haney, D.E. Riederer, Delayed extraction for improved resolution of ion/surface collision products by time-of-flight mass spectrometry, Analytica Chimica Acta, 397 (1999) 225-233.

[71] E. Stone, K.J. Gillig, B. Ruotolo, K. Fuhrer, M. Gonin, A. Schultz, D.H. Russell, Surface-induced dissociation on a MALDI-ion mobility-orthogonal time-of-flight mass spectrometer: Sequencing peptides from an "in-solution" protein digest, Analytical Chemistry, 73 (2001) 2233-2238.

[72] C.M. Gamage, F.M. Fernandez, K. Kuppannan, V.H. Wysocki, Submicrosecond surface-induced dissociation of peptide ions in a MALDI TOF MS, Analytical Chemistry, 76 (2004) 5080-5091.

[73] E.N. Nikolaev, A. Somogyi, D.L. Smith, C.G. Gu, V.H. Wysocki, C.D. Martin, G.L. Samuelson, Implementation of low-energy surface-induced dissociation (eV SID) and high-energy collision-induced dissociation (keV CID) in a linear sector-TOF hybrid tandem mass spectrometer, International Journal of Mass Spectrometry, 212 (2001) 535-551.

[74] C.F. Ijames, C.L. Wilkins, Surface-induced dissociation by fourier-transform mass-spectrometry, Analytical Chemistry, 62 (1990) 1295-1299.

[75] J. Laskin, E.V. Denisov, A.K. Shukla, S.E. Barlow, J.H. Futrell, Surface-induced dissociation in a Fourier transform ion cyclotron resonance mass spectrometer: Instrument design and evaluation, Analytical Chemistry, 74 (2002) 3255-3261.

[76] R.A. Chorush, D.P. Little, S.C. Beu, T.D. Wood, F.W. McLafferty, Surface-induced dissociation of multiply protonated proteins, Analytical Chemistry, 67 (1995) 1042-1046.

[77] W.Q. Zhong, E.N. Nikolaev, J.H. Futrell, V.H. Wysocki, Tandem Fourier transform mass spectrometry studies of surface-induced dissociation of benzene monomer and dimer ions on a self-assembled fluorinated alkanethiolate monolayer surface, Analytical Chemistry, 69 (1997) 2496-2503.

[78] V.S. Rakov, J.H. Futrell, E.V. Denisov, E.N. Nikolaev, Instrumentation of kinetic energy-resolved surface-induced dissociation in Fourier transform mass spectrometry, European Journal of Mass Spectrometry, 6 (2000) 299-317.

[79] W.J. Sun, J.C. May, D.H. Russell, A novel surface-induced dissociation instrument for ion mobilitytime-of-flight mass spectrometry, International Journal of Mass Spectrometry, 259 (2007) 79-86. 
[80] W.J. Sun, J.C. May, K.J. Gillig, D.H. Russell, A dual time-of-flight apparatus for an ion mobilitysurface-induced dissociation-mass spectrometer for high-throughput peptide sequencing, International Journal of Mass Spectrometry, 287 (2009) 39-45.

[81] M.W. Zhou, C.S. Huang, V.H. Wysocki, Surface-Induced Dissociation of Ion Mobility-Separated Noncovalent Complexes in a Quadrupole/Time-of-Flight Mass Spectrometer, Analytical Chemistry, 84 (2012) 6016-6023.

[82] A. Budrevich, B. Tsipinyuk, A. Bekkerman, E. Kolodney, Surface scattering of hyperthermal (10-50 eV) neutral $C_{60}$ : Angular and energy distributions, Journal of Chemical Physics, 106 (1997) 5771-5774. [83] J. Kubista, Z. Dolejsek, Z. Herman, Energy partitioning in collisions of slow polyatomic ions with surfaces: ethanol molecular ions on stainless steel surfaces, European Mass Spectrometry, 4 (1998) 311319.

[84] R. Worgotter, J. Kubista, J. Zabka, Z. Dolejsek, T.D. Mark, Z. Herman, Surface-induced reactions and decomposition of the benzene molecular ion $\mathrm{C} 6 \mathrm{H6} 6$ : Product ion intensities, angular and translational energy distributions, International Journal of Mass Spectrometry, 174 (1998) 53-62.

[85] H.L. de Clercq, A.D. Sen, A.K. Shukla, J.H. Futrell, Inelastic ion-surface collisions: scattering and dissociation of low energy benzene molecular cations, International Journal of Mass Spectrometry, 212 (2001) 491-504.

[86] A.K. Shukla, J.H. Futrell, A beam scattering instrument for the dynamics studies of surface-induced dissociation processes, Review of Scientific Instruments, 74 (2003) 168-175.

[87] B.E. Winger, R.K. Julian, R.G. Cooks, C.E.D. Chidsey, Surface-reactions and surface-induced dissociation of polyatomic ions at self-assembled organic monolayer surfaces, Journal of the American Chemical Society, 113 (1991) 8967-8969.

[88] V.H. Wysocki, J.L. Jones, J.M. Ding, Polyatomic ion/surface collisions at self-assembled monolayers films, Journal of the American Chemical Society, 113 (1991) 8969-8970.

[89] J. Laskin, J.H. Futrell, Energy transfer in collisions of peptide ions with surfaces, Journal of Chemical Physics, 119 (2003) 3413-3420.

[90] U. Heiz, E.L. Bullock, Fundamental aspects of catalysis on supported metal clusters, Journal of Materials Chemistry, 14 (2004) 564-577.

[91] D.-C. Lim, C.-C. Hwang, G. Gantefor, Y.D. Kim, Model catalysts of supported Au nanoparticles and mass-selected clusters, Physical Chemistry Chemical Physics, 12 (2010) 15172-15180.

[92] Z. Herman, Collisions of slow polyatomic ions with surfaces: The scattering method and results, Journal of the American Society for Mass Spectrometry, 14 (2003) 1360-1372.

[93] K.Y. Song, O. Meroueh, W.L. Hase, Dynamics of $\mathrm{Cr}(\mathrm{CO})_{6}{ }^{+}$collisions with hydrogenated surfaces, Journal of Chemical Physics, 118 (2003) 2893-2902.

[94] J. Kubišta, Z. Dolejšek, Z. Herman, Energy partitioning in collisions of slow polyatomic ions with surfaces: ethanol molecular ions on stainless steel surfaces, European Journal of Mass Spectrometry, 4 (1998) 311-319.

[95] R. Wörgötter, J. Kubišta, J. Žabka, Z. Dolejšek, T.D. Märk, Z. Herman, Surface-induced reactions and decomposition of the benzene molecular ion $\mathrm{C}_{6} \mathrm{H}_{6}{ }^{+}$: Product ion intensities, angular and translational energy distributions, International Journal of Mass Spectrometry and Ion Processes, 174 (1998) 53-62.

[96] J. Roithova, J. Zabka, Z. Dolejsek, Z. Herman, Collisions of slow polyatomic ions with surfaces: Dissociation and chemical reactions of $\mathrm{CD}_{5}{ }^{+}, \mathrm{CD}_{4}{ }^{+}, \mathrm{CD}_{3}{ }^{+}$, and their isotopic variants on room-temperature and heated carbon surfaces, Journal of Physical Chemistry B, 106 (2002) 8293-8301.

[97] A.K. Shukla, J.H. Futrell, Dynamics of hyperthermal energy ion-surface collisions: dissociative and non-dissociative scattering of ethanol cations from a self-assembled monolayer surface of fluorinated alkyl thiol on Au(111), International Journal of Mass Spectrometry, 223 (2003) 783-801. 
[98] A.K. Shukla, J.H. Futrell, A.D. Sen, Dynamics of the dissociative and nondissociative scattering of hyperthermal $\mathrm{CS}_{2}{ }^{+}$from a self-assembled fluoroalkyl monolayer surface on gold substrate, Journal of Chemical Physics, 118 (2003) 11217-11225.

[99] J.W. Shen, Y.H. Yim, B.B. Feng, V. Grill, C. Evans, R.G. Cooks, Soft landing of ions onto self-assembled hydrocarbon and fluorocarbon monolayer surfaces, International Journal of Mass Spectrometry, 183 (1999) 423-435.

[100] D.L. Smith, V.H. Wysocki, R. Colorado, O.E. Shmakova, M. Graupe, T.R. Lee, Low-energy ion-surface collisions characterize alkyland fluoroalkyl-terminated self-assembled monolayers on gold, Langmuir, 18 (2002) 3895-3902.

[101] J. Zabka, Z. Dolejsek, Z. Herman, Energy partitioning in collisions of slow polyatomic ions with surfaces: Ethanol molecular ions on surfaces covered by self-assembled monolayers (CF-SAM, CH-SAM, COOH-SAM), Journal of Physical Chemistry A, 106 (2002) 10861-10869.

[102] J. Laskin, E. Denisov, J. Futrell, A comparative study of collision-induced and surface-induced dissociation. 1. Fragmentation of protonated dialanine, Journal of the American Chemical Society, 122 (2000) 9703-9714.

[103] O. Meroueh, W.L. Hase, Dynamics of energy transfer in peptide-surface collisions, Journal of the American Chemical Society, 124 (2002) 1524-1531.

[104] S.B.M. Bosio, W.L. Hase, Simulations of energy transfer in $\mathrm{Cr}(\mathrm{CO})_{6}{ }^{+}$surface-induced dissociation, International Journal of Mass Spectrometry, 174 (1998) 1-9.

[105] O. Meroueh, W.L. Hase, Energy transfer pathways in the collisional activation of peptides, International Journal of Mass Spectrometry, 201 (2000) 233-244.

[106] J.P. Wang, S.O. Meroueh, Y.F. Wang, W.L. Hase, Efficiency of energy transfer in protonated diglycine and dialanine SID - Effects of collision angle, peptide ion size, and intramolecular potential, International Journal of Mass Spectrometry, 230 (2003) 57-64.

[107] A. Rahaman, W.L. Hase, K. Song, J. Wang, O. Meroueh, Chemical Dynamics Simulations of Energy Transfer and Unimolecular Decomposition in Collision-Induced Dissociation (CID) and Surface-Induced Dissociation (SID), in: J. Laskin, C. Lifshitz (Eds.) Principles of Mass Spectrometry Applied to Biomolecules, John Wiley \& Sons., Inc., Hoboken, NJ, 2006.

[108] G.L. Barnes, W.L. Hase, Energy Transfer, Unfolding, and Fragmentation Dynamics in Collisions of NProtonated Octaglycine with an H-SAM Surface, Journal of the American Chemical Society, 131 (2009) 17185-17193.

[109] L. Yang, O.A. Mazyar, U. Lourderaj, J.P. Wang, M.T. Rodgers, E. Martinez-Nunez, S.V. Addepalli, W.L. Hase, Chemical dynamics simulations of energy transfer in collisions of protonated peptide-ions with a perfluorinated alkylthiol self-assembled monolayer surface, Journal of Physical Chemistry C, 112 (2008) 9377-9386.

[110] J. Laskin, T.H. Bailey, E.V. Denisov, J.H. Futrell, On the relative stability of singly protonated des$\mathrm{Arg}^{1-}$ and des-Arg'-bradykinins, Journal of Physical Chemistry A, 106 (2002) 9832-9836.

[111] J. Laskin, J.H. Futrell, On the efficiency of energy transfer in collisional activation of small peptides, Journal of Chemical Physics, 116 (2002) 4302-4310.

[112] K. Vekey, A. Somogyi, V.H. Wysocki, Internal energy-distribution of benzene molecular-ions in surface-induced dissociation, Journal of Mass Spectrometry, 30 (1995) 212-217.

[113] S.O. Meroueh, Y.F. Wang, W.L. Hase, Direct dynamics Simulations of collision- and surface-induced dissociation of N-protonated glycine. Shattering fragmentation, Journal of Physical Chemistry A, 106 (2002) 9983-9992.

[114] K. Park, B. Deb, K. Song, W.L. Hase, Importance of Shattering Fragmentation in the SurfaceInduced Dissociation of Protonated Octaglycine, Journal of the American Society for Mass Spectrometry, 20 (2009) 939-948. 
[115] J. Laskin, J.H. Futrell, Surface-induced dissociation of peptide ions: Kinetics and dynamics, Journal of the American Society for Mass Spectrometry, 14 (2003) 1340-1347.

[116] J. Laskin, K.M. Beck, J.J. Hache, J.H. Futrell, Surface-induced dissociation of ions produced by matrix-assisted laser desorption/ionization in a Fourier transform ion cyclotron resonance mass spectrometer, Analytical Chemistry, 76 (2004) 351-356.

[117] F.M. Fernandez, V.H. Wysocki, J.H. Futrell, J. Laskin, Protein identification via surface-induced dissociation in an FT-ICR mass spectrometer and a patchwork sequencing approach, Journal of the American Society for Mass Spectrometry, 17 (2006) 700-709.

[118] J.L. Jones, A.R. Dongre, A. Somogyi, V.H. Wysocki, Sequence dependence of peptide fragmentation efficiency curves determined by electrospray-ionization surface-induced dissociation massspectrometry, Journal of the American Chemical Society, 116 (1994) 8368-8369.

[119] G. Tsaprailis, H. Nair, A. Somogyi, V.H. Wysocki, W.Q. Zhong, J.H. Futrell, S.G. Summerfield, S.J. Gaskell, Influence of secondary structure on the fragmentation of protonated peptides, Journal of the American Chemical Society, 121 (1999) 5142-5154.

[120] H. Nair, V.H. Wysocki, Are peptides without basic residues protonated primarily at the amino terminus?, International Journal of Mass Spectrometry, 174 (1998) 95-100.

[121] V.H. Wysocki, G. Tsaprailis, L.L. Smith, L.A. Breci, Special feature: Commentary - Mobile and localized protons: a framework for understanding peptide dissociation, Journal of Mass Spectrometry, 35 (2000) 1399-1406.

[122] C.G. Gu, G. Tsaprailis, L. Breci, V.H. Wysocki, Selective gas-phase cleavage at the peptide bond terminal to aspartic acid in fixed-charge derivatives of asp-containing peptides, Analytical Chemistry, 72 (2000) 5804-5813.

[123] G. Tsaprailis, A. Somogyi, E.N. Nikolaev, V.H. Wysocki, Refining the model for selective cleavage at acidic residues in arginine-containing protonated peptides, International Journal of Mass Spectrometry, 195 (2000) 467-479.

[124] Y.Y. Huang, V.H. Wysocki, D.L. Tabb, J.R. Yates, The influence of histidine on cleavage C-terminal to acidic residues in doubly protonated tryptic peptides, International Journal of Mass Spectrometry, 219 (2002) 233-244.

[125] J. Laskin, T.H. Bailey, J.H. Futrell, Mechanisms of peptide fragmentation from time- and energyresolved surface-induced dissociation studies: Dissociation of angiotensin analogs, International Journal of Mass Spectrometry, 249 (2006) 462-472.

[126] J.M. Spraggins, J.A. Lloyd, M.V. Johnston, J. Laskin, D.P. Ridge, Fragmentation mechanisms of oxidized peptides elucidated by SID, RRKM modeling, and molecular dynamics, Journal of the American Society for Mass Spectrometry, 20 (2009) 1579-1592.

[127] J. Laskin, Z.B. Yang, T. Song, C. Lam, I.K. Chu, Effect of the basic residue on the energetics, dynamics, and mechanisms of gas-phase fragmentation of protonated peptides, Journal of the American Chemical Society, 132 (2010) 16006-16016.

[128] T.H. Bailey, J. Laskin, J.H. Futrell, Energetics of selective cleavage at acidic residues studied by timeand energy-resolved surface-induced dissociation in FT-ICR MS, International Journal of Mass Spectrometry, 222 (2003) 313-327.

[129] J. Laskin, T.H. Bailey, J.H. Futrell, Fragmentation energetics for angiotensin II and its analogs from time-and energy-resolved surface-induced dissociation studies, International Journal of Mass Spectrometry, 234 (2004) 89-99.

[130] J. Laskin, Energy and entropy effects in the gas phase dissociation of peptides and proteins, in: J. Laskin, C. Lifshitz (Eds.) Principles of Mass Spectrometry Applied to Biomolecules, John Wiley \& Sons., Inc., Hoboken, NJ, 2006. 
[131] J. Laskin, Energetics and dynamics of fragmentation of protonated leucine enkephalin from timeand energy-resolved surface-induced dissociation studies, Journal of Physical Chemistry A, 110 (2006) 8554-8562.

[132] J. Laskin, M. Byrd, J. Futrell, Internal energy distributions resulting from sustained off-resonance excitation in $\mathrm{ftms}$. I. Fragmentation of the bromobenzene radical cation, International Journal of Mass Spectrometry, 195 (2000) 285-302.

[133] J. Laskin, J. Futrell, Internal energy distributions resulting from sustained off-resonance excitation in fourier transform ion cyclotron resonance mass spectrometry. li. Fragmentation of the 1bromonaphthalene radical cation, Journal of Physical Chemistry A, 104 (2000) 5484-5494.

[134] H. Lioe, J. Laskin, G.E. Reid, R.A.J. O'Hair, Energetics and dynamics of the fragmentation reactions of protonated peptides containing methionine sulfoxide or aspartic acid via energy- and time-resolved surface induced dissociation, Journal of Physical Chemistry A, 111 (2007) 10580-10588.

[135] I.K. Chu, J. Laskin, Review formation of peptide radical ions through dissociative electron transfer in ternary metal-ligand-peptide complexes, European Journal of Mass Spectrometry, 17 (2011) 543-556. [136] J. Laskin, Z. Yang, I.K. Chu, Energetics and dynamics of electron transfer and proton transfer in dissociation of metal'"(salen)-peptide complexes in the gas phase, Journal of the American Chemical Society, 130 (2008) 3218-3230.

[137] J. Laskin, J.H. Futrell, I.K. Chu, Is dissociation of peptide radical cations an ergodic process?, Journal of the American Chemical Society, 129 (2007) 9598-+.

[138] Z.B. Yang, C. Lam, I.K. Chu, J. Laskin, The effect of the secondary structure on dissociation of peptide radical cations: Fragmentation of angiotensin III and its analogues, Journal of Physical Chemistry B, 112 (2008) 12468-12478.

[139] J. Laskin, Z.B. Yang, C. Lam, I.K. Chu, Energy and entropy effects in dissociation of peptide radical anions, International Journal of Mass Spectrometry, 316 (2012) 251-258.

[140] J.C. Jurchen, E.R. Williams, Origin of asymmetric charge partitioning in the dissociation of gasphase protein homodimers, Journal of the American Chemical Society, 125 (2003) 2817-2826.

[141] C.M. Jones, R.L. Beardsley, A.S. Galhena, S. Dagan, G.L. Cheng, V.H. Wysocki, Symmetrical gasphase dissociation of noncovalent protein complexes via surface collisions, Journal of the American Chemical Society, 128 (2006) 15044-15045.

[142] A.E. Blackwell, E.D. Dodds, V. Bandarian, V.H. Wysocki, Revealing the Quaternary Structure of a Heterogeneous Noncovalent Protein Complex through Surface-Induced Dissociation, Analytical Chemistry, 83 (2011) 2862-2865.

[143] E.D. Dodds, A.E. Blackwell, C.M. Jones, K.L. Holso, D.J. O'Brien, M.H.J. Cordes, V.H. Wysocki, Determinants of Gas-Phase Disassembly Behavior in Homodimeric Protein Complexes with Related Yet Divergent Structures, Analytical Chemistry, 83 (2011) 3881-3889.

[144] M.W. Zhou, S. Dagan, V.H. Wysocki, Protein Subunits Released by Surface Collisions of Noncovalent Complexes: Nativelike Compact Structures Revealed by Ion Mobility Mass Spectrometry, Angewandte Chemie-International Edition, 51 (2012) 4336-4339.

[145] M.W. Zhou, S. Dagan, V.H. Wysocki, Impact of charge state on gas-phase behaviors of noncovalent protein complexes in collision induced dissociation and surface induced dissociation, Analyst, 138 (2013) 1353-1362.

[146] M.W. Zhou, C.M. Jones, V.H. Wysocki, Dissecting the Large Noncovalent Protein Complex GroEL with Surface-Induced Dissociation and Ion Mobility Mass Spectrometry, Analytical Chemistry, 85 (2013) 8262-8267.

[147] A.K. Badu-Tawiah, J. Cyriac, R.G. Cooks, Reactions of Organic lons at Ambient Surfaces in a SolventFree Environment, Journal of the American Society for Mass Spectrometry, 23 (2012) 842-849.

[148] A.K. Badu-Tawiah, C.P. Wu, R.G. Cooks, Ambient lon Soft Landing, Analytical Chemistry, 83 (2011) 2648-2654. 
[149] J.W. Shen, C. Evans, N. Wade, R.G. Cooks, Ion-ion collisions leading to formation of C-C bonds at surfaces: An interfacial Kolbe reaction, Journal of the American Chemical Society, 121 (1999) 9762-9763. [150] J. Alvarez, J.H. Futrell, J. Laskin, Soft-landing of peptides onto self-assembled monolayer surfaces, Journal of Physical Chemistry A, 110 (2006) 1678-1687.

[151] M.B.J. Wijesundara, Y. Ji, B. Ni, S.B. Sinnott, L. Hanley, Effect of polyatomic ion structure on thinfilm growth: Experiments and molecular dynamics simulations, Journal of Applied Physics, 88 (2000) 5004-5016.

[152] N. Wade, C. Evans, S.C. Jo, R.G. Cooks, Silylation of an OH-terminated self-assembled monolayer surface through low-energy collisions of ions: a novel route to synthesis and patterning of surfaces, Journal of Mass Spectrometry, 37 (2002) 591-602.

[153] N. Wade, B. Gologan, A. Vincze, R.G. Cooks, D.M. Sullivan, M.L. Bruening, Esterification and ether formation at a hydroxyl-terminated self-assembled monolayer surface using low-energy collisions of polyatomic cations, Langmuir, 18 (2002) 4799-4808.

[154] P. Wang, O. Hadjar, J. Laskin, Covalent immobilization of peptides on self-assembled monolayer surfaces using soft-landing of mass-selected ions, Journal of the American Chemical Society, 129 (2007) 8682-8683.

[155] P. Wang, O. Hadjar, P.L. Gassman, J. Laskin, Reactive landing of peptide ions on self-assembled monolayer surfaces: an alternative approach for covalent immobilization of peptides on surfaces, Physical Chemistry Chemical Physics, 10 (2008) 1512-1522.

[156] Q.C. Hu, J. Laskin, Reactive landing of dendrimer ions onto activated self-assembled monolayer surfaces, Journal of Physical Chemistry C, (2014).

[157] S. Nagaoka, K. Ikemoto, K. Horiuchi, A. Nakajima, Soft- and Reactive-Landing of Cr(aniline) ${ }_{2}$ Sandwich Complexes onto Self-Assembled Monolayers: Separation between Functional and Binding Sites, Journal of the American Chemical Society, 133 (2011) 18719-18727.

[158] M. Volny, W.T. Elam, B.D. Ratner, F. Turecek, Preparative soft and reactive landing of gas-phase ions on plasma-treated metal surfaces, Analytical Chemistry, 77 (2005) 4846-4853.

[159] G.E. Johnson, J. Laskin, Preparation of Surface Organometallic Catalysts by Gas-Phase Ligand Stripping and Reactive Landing of Mass-Selected lons, Chemistry - A European Journal, 16 (2010) 1443314438.

[160] M. Mitsui, S. Nagaoka, T. Matsumoto, A. Nakajima, Soft-landing isolation of vanadium-benzene sandwich clusters on a room-temperature substrate using $\mathrm{n}$-alkanethiolate self-assembled monolayer matrixes, Journal of Physical Chemistry B, 110 (2006) 2968-2971.

[161] S. Nagaoka, K. Ikemoto, K. Horiuchi, A. Nakajima, Soft- and Reactive-Landing of $\mathrm{Cr}($ aniline)(2) Sandwich Complexes onto Self-Assembled Monolayers: Separation between Functional and Binding Sites, Journal of the American Chemical Society, 133 (2011) 18719-18727.

[162] J. Laskin, P. Wang, O. Hadjar, Soft-landing of Co'l'(salen) ${ }^{+}$and MnIII(salen) ${ }^{+}$on self-assembled monolayer surfaces, Journal of Physical Chemistry C, 114 (2010) 5305-5311.

[163] N. Thontasen, G. Levita, N. Malinowski, Z. Deng, S. Rauschenbach, K. Kern, Grafting Crown Ether Alkali Host-Guest Complexes at Surfaces by Electrospray Ion Beam Deposition, Journal of Physical Chemistry C, 114 (2010) 17768-17772.

[164] L. Hanley, H.J. Lim, D.G. Schultz, S.B. Wainhaus, P. deSainteClaire, W.L. Hase, Surface energy transfer by low energy polyatomic ion collisions, Nuclear Instruments \& Methods in Physics Research Section B-Beam Interactions with Materials and Atoms, 125 (1997) 218-222.

[165] S.C. Nanita, Z. Takats, R.G. Cooks, S. Myung, D.E. Clemmer, Chiral enrichment of serine via formation, dissociation, and soft-landing of octameric cluster ions, Journal of the American Society for Mass Spectrometry, 15 (2004) 1360-1365. 
[166] B. Wang, B. Yoon, M. Konig, Y. Fukamori, F. Esch, U. Heiz, U. Landman, Size-Selected Monodisperse Nanoclusters on Supported Graphene: Bonding, Isomerism, and Mobility, Nano Letters, 12 (2012) 59075912.

[167] B. Yoon, H. Hakkinen, U. Landman, A.S. Worz, J.M. Antonietti, S. Abbet, K. Judai, U. Heiz, Charging effects on bonding and catalyzed oxidation of $\mathrm{CO}$ on $\mathrm{Au}_{8}$ clusters on MgO, Science, 307 (2005) 403-407. [168] G. Kwon, G.A. Ferguson, C.J. Heard, E.C. Tyo, C.R. Yin, J. DeBartolo, S. Seifert, R.E. Winans, A.J. Kropf, J. Greeley, R.L. Johnston, L.A. Curtiss, M.J. Pellin, S. Vajda, Size-Dependent Subnanometer Pd Cluster $\left(\mathrm{Pd}_{4}, \mathrm{Pd}_{6}\right.$, and $\left.\mathrm{Pd}_{17}\right)$ Water Oxidation Electrocatalysis, Acs Nano, 7 (2013) 5808-5817.

[169] Y. Lei, F. Mehmood, S. Lee, J. Greeley, B. Lee, S. Seifert, R.E. Winans, J.W. Elam, R.J. Meyer, P.C. Redfern, D. Teschner, R. Schlogl, M.J. Pellin, L.A. Curtiss, S. Vajda, Increased Silver Activity for Direct Propylene Epoxidation via Subnanometer Size Effects, Science, 328 (2010) 224-228.

[170] B. Gologan, Z. Takats, J. Alvarez, J.M. Wiseman, N. Talaty, Z. Ouyang, R.G. Cooks, lon soft-landing into liquids: Protein identification, separation, and purification with retention of biological activity, Journal of the American Society for Mass Spectrometry, 15 (2004) 1874-1884.

[171] P. Wang, J. Laskin, Helical peptide arrays on self-assembled monolayer surfaces through soft and reactive landing of mass-selected ions, Angewandte Chemie-International Edition, 47 (2008) 6678-6680. [172] B.B. Feng, D.S. Wunschel, C.D. Masselon, L. Pasa-Tolic, R.D. Smith, Retrieval of DNA using softlanding after mass analysis by ESI-FTICR for enzymatic manipulation, Journal of the American Chemical Society, 121 (1999) 8961-8962.

[173] G. Siuzdak, B. Bothner, M. Yeager, C. Brugidou, C.M. Fauquet, K. Hoey, C.M. Chang, Mass spectrometry and viral analysis, Chemistry \& Biology, 3 (1996) 45-48.

[174] D. Loffler, S.S. Jester, P. Weis, A. Bottcher, M.M. Kappes, $C_{n}$ films ( $n=50,52,54,56$, and 58) on graphite: Cage size dependent electronic properties, Journal of Chemical Physics, 124 (2006) 054705. [175] D. Loffler, S. Ulas, S.S. Jester, P. Weis, A. Bottcher, M.M. Kappes, Properties of non-IPR fullerene films versus size of the building blocks, Physical Chemistry Chemical Physics, 12 (2010) 10671-10684. [176] S. Ulas, D. Strelnikov, P. Weis, A. Bottcher, M.M. Kappes, Incorporating $C_{2}$ into $C_{60}$ films, Journal of Chemical Physics, 136 (2012) 014701.

[177] G.R. Blacken, M. Volny, T. Vaisar, M. Sadılek, F. Turecek, In Situ Enrichment of Phosphopeptides on MALDI Plates Functionalized by Reactive Landing of Zirconium(IV)-n-Propoxide Ions, Analytical Chemistry, 79 (2007) 5449-5456.

[178] W. Hoffmann, G. Verbeck, Toward a Reusable Surface-Enhanced Raman Spectroscopy (SERS) Substrate by Soft-Landing Ion Mobility, Appl. Spectrosc., 67 (2013) 656-660.

[179] A.A. Tsekouras, M.J. ledema, J.P. Cowin, Soft-landed ion diffusion studies on vapor-deposited hydrocarbon films, Journal of Chemical Physics, 111 (1999) 2222-2234.

[180] W.P. Peng, G.E. Johnson, I.C. Fortmeyer, P. Wang, O. Hadjar, R.G. Cooks, J. Laskin, Redox chemistry in thin layers of organometallic complexes prepared using ion soft landing, Physical Chemistry Chemical Physics, 13 (2011) 267-275.

[181] N. Hauptmann, C. Hamann, H. Tang, R. Berndt, Switching and charging of a ruthenium dye on $\mathrm{Ag}(111)$, Physical Chemistry Chemical Physics, 15 (2013) 10326-10330.

[182] Q.C. Hu, P. Wang, J. Laskin, Effect of the surface on the secondary structure of soft landed peptide ions, Physical Chemistry Chemical Physics, 12 (2010) 12802-12810.

[183] S. Kahle, Z.T. Deng, N. Malinowski, C. Tonnoir, A. Forment-Aliaga, N. Thontasen, G. Rinke, D. Le, V. Turkowski, T.S. Rahman, S. Rauschenbach, M. Ternes, K. Kern, The Quantum Magnetism of Individual Manganese-12-Acetate Molecular Magnets Anchored at Surfaces, Nano Letters, 12 (2012) 518-521. [184] O. Hadjar, J.H. Futrell, J. Laskin, First observation of charge reduction and desorption kinetics of multiply protonated peptides soft landed onto self-assembled monolayer surfaces, Journal of Physical Chemistry C, 111 (2007) 18220-18225. 
[185] G.L. Barnes, K. Young, L. Yang, W.L. Hase, Fragmentation and reactivity in collisions of protonated diglycine with chemically modified perfluorinated alkylthiolate-self-assembled monolayer surfaces, Journal of Chemical Physics, 134 (2011) 094106.

[186] J. Laskin, P. Wang, O. Hadjar, J.H. Futrell, J. Alvarez, Z.G. Cooks, Charge retention by peptide ions soft-landed onto self-assembled monolayer surfaces, International Journal of Mass Spectrometry, 265 (2007) 237-243.

[187] G.E. Johnson, T. Priest, J. Laskin, Charge retention by gold clusters on surfaces prepared using soft landing of mass selected ions, ACS Nano, 6 (2012) 573-582.

[188] G.E. Johnson, T. Priest, J. Laskin, Coverage-dependent charge reduction of cationic gold clusters on surfaces prepared using soft landing of mass-selected ions, Journal of Physical Chemistry C, 116 (2012) 24977-24986.

[1] J.J. Thomson, Rays of positive electricity and their application to chemical analyses, Longmans, Green and Co., London, New York, 1913.

[2] V. Franchetti, B.H. Solka, W.E. Baitinger, J.W. Amy, R.G. Cooks, Soft Landing of lons as a Means of Surface Modification, International Journal of Mass Spectrometry and Ion Processes, 23 (1977) 29-35.

[3] M.D.A. Mabud, M.J. Dekrey, R.G. Cooks, Surface-induced dissociation of molecular ions, International Journal of Mass Spectrometry and Ion Processes, 67 (1985) 285-294.

[4] A.R. Dongre, A. Somogyi, V.H. Wysocki, Surface-induced dissociation: An effective tool to probe structure, energetics and fragmentation mechanisms of protonated peptides, Journal of Mass Spectrometry, 31 (1996) 339-350.

[5] A.R. Dongre, J.L. Jones, A. Somogyi, V.H. Wysocki, Influence of peptide composition, gas-phase basicity, and chemical modification on fragmentation efficiency: Evidence for the mobile proton model, Journal of the American Chemical Society, 118 (1996) 8365-8374.

[6] V. Grill, J. Shen, C. Evans, R.G. Cooks, Collisions of ions with surfaces at chemically relevant energies: Instrumentation and phenomena, Review of Scientific Instruments, 72 (2001) 3149-3179.

[7] B. Gologan, J.M. Wiseman, R.G. Cooks, lon Soft Landing: Instrumentation, Phenomena, and Applications, in: J. Laskin, C. Lifshitz (Eds.) Principles of Mass Spectrometry Applied to Biomolecules, John Wiley \& Sons., Inc., Hoboken, NJ, 2006.

[8] J. Cyriac, T. Pradeep, H. Kang, R. Souda, R.G. Cooks, Low-Energy lonic Collisions at Molecular Solids, Chemical Reviews, 112 (2012) 5356-5411.

[9] J. Laskin, P. Wang, O. Hadjar, Soft-landing of peptide ions onto self-assembled monolayer surfaces: an overview, Physical Chemistry Chemical Physics, 10 (2008) 1079-1090.

[10] G.E. Johnson, Q.C. Hu, J. Laskin, Soft Landing of Complex Molecules on Surfaces, Annual Review of Analytical Chemistry, 4 (2011) 83-104.

[11] G. Verbeck, W. Hoffmann, B. Walton, Soft-landing preparative mass spectrometry, Analyst, 137 (2012) 4393-4407.

[12] V.H. Wysocki, K.E. Joyce, C.M. Jones, R.L. Beardsley, Surface-induced dissociation of small molecules, peptides, and non-covalent protein complexes, Journal of the American Society for Mass Spectrometry, 19 (2008) 190-208.

[13] R.G. Cooks, T. Ast, A. Mabud, Collisions of polyatomic ions with surfaces, International Journal of Mass Spectrometry, 100 (1990) 209-265.

[14] R.G. Cooks, T. Ast, T. Pradeep, V. Wysocki, Reactions of ions with organic surfaces, Accounts of Chemical Research, 27 (1994) 316-323.

[15] P. Wang, J. Laskin, Surface Modification Using Reactive Landing of Mass-Selected lons, in: R. Hellborg, H.J. Whitlow, Y. Zhang (Eds.) Ion Beams in Nanoscience and Technology, Springer, London, New York, 2009. 
[16] T. Raz, R.D. Levine, On the shattering of clusters by surface impact heating, Journal of Chemical Physics, 105 (1996) 8097-8102.

[17] W. Christen, U. Even, T. Raz, R.D. Levine, Collisional energy loss in cluster surface impact:

Experimental, model, and simulation studies of some relevant factors, Journal of Chemical Physics, 108 (1998) 10262-10273.

[18] W. Christen, U. Even, Cluster impact chemistry, Journal of Physical Chemistry A, 102 (1998) 94209426.

[19] R.D. Beck, C. Warth, K. May, M.M. Kappes, Surface impact induced shattering of $C_{60}$. Detection of small $C_{m}$ fragments by negative surface ionization, Chemical Physics Letters, 257 (1996) 557-562.

[20] O. Meroueh, W.L. Hase, Effect of surface stiffness on the efficiency of surface-induced dissociation, Physical Chemistry Chemical Physics, 3 (2001) 2306-2314.

[21] J. Laskin, T.H. Bailey, J.H. Futrell, Shattering of peptide ions on self-assembled monolayer surfaces, Journal of the American Chemical Society, 125 (2003) 1625-1632.

[22] T. Ast, D.E. Riederer, S.A. Miller, M. Morris, R.G. Cooks, Collisions of fluorocarbon ions at solidsurfaces - electronic excitation, surface-induced dissociation and chemical sputtering, Organic Mass Spectrometry, 28 (1993) 1021-1033.

[23] C. Xirouchaki, R.E. Palmer, Pinning and implantation of size-selected metal clusters: a topical review, Vacuum, 66 (2002) 167-173.

[24] N. Winograd, B.J. Garrison, Biological Cluster Mass Spectrometry, Annual Review of Physical Chemistry, 61 (2010) 305-322.

[25] R.J. Day, S.E. Unger, R.G. Cooks, Molecular secondary ion mass-spectrometry, Analytical Chemistry, 52 (1980) A557-\&.

[26] A. Benninghoven, Chemical-analysis of inorganic and organic-surfaces and thin-films by static timeof-flight secondary-ion mass-spectrometry (TOF-SIMS), Angew. Chem.-Int. Edit. Engl., 33 (1994) 10231043.

[27] L. Hanley, S.B. Sinnott, The growth and modification of materials via ion-surface processing, Surface Science, 500 (2002) 500-522.

[28] D.C. Jacobs, Reactive collisions of hyperthermal energy molecular ions with solid surfaces, Annual Review of Physical Chemistry, 53 (2002) 379-407.

[29] B. Gologan, J.R. Green, J. Alvarez, J. Laskin, R.G. Cooks, lon/surface reactions and ion soft-landing, Physical Chemistry Chemical Physics, 7 (2005) 1490-1500.

[30] R.W. Gurney, The scattering of positive ions from a platinum surface, Phys. Rev., 32 (1928) 04670477.

[31] C.C. Van Voorhis, K.T. Compton, Accommodation coefficients of positive ions of argon, neon and helium, Phys. Rev., 37 (1931) 1596-1610.

[32] K.S. Woodcock, The emission of negative ions under the bombardment of positive ions, Phys. Rev., 38 (1931) 1696-1703.

[33] R.E. Honig, The development of secondary ion mass-spectrometry (SIMS) - A retrospective, International Journal of Mass Spectrometry and Ion Processes, 66 (1985) 31-54.

[34] J.H. Beynon, A.E. Fontaine, G.R. Lester, An anomalous metastable peak in mass spectrum of methanol, Chem. Commun., (1968) 265-\&.

[35] R.G. Cooks, Metastable ions, Elsevier Scientific Pub. Co., 1973.

[36] C. Lifshitz, M. Shapiro, Sternber.R, Isotope effects on metastable transitions .4. Isotopic methanols, Isr. J. Chem., 7 (1969) 391-\&.

[37] R.G. Cooks, T. Ast, J.H. Beynon, Anomalous metastable peaks, International Journal of Mass Spectrometry and lon Processes, 16 (1975) 348-352.

[38] R.G. Cooks, D.T. Terwilliger, T. Ast, J.H. Beynon, T. Keough, Surface modified mass-spectrometry, Journal of the American Chemical Society, 97 (1975) 1583-1585. 
[39] S.A. Miller, H. Luo, S.J. Pachuta, R.G. Cooks, Soft-landing of polyatomic ions at fluorinated selfassembled monolayer surfaces, Science, 275 (1997) 1447-1450.

[40] A. Bottcher, P. Weis, S.S. Jester, D. Loffler, A. Bihlmeier, W. Klopper, M.M. Kappes, Solid C films, $_{\text {, }}$ Physical Chemistry Chemical Physics, 7 (2005) 2816-2820.

[41] Z. Ouyang, Z. Takats, T.A. Blake, B. Gologan, A.J. Guymon, J.M. Wiseman, J.C. Oliver, V.J. Davisson, R.G. Cooks, Preparing protein microarrays by soft-landing of mass-selected ions, Science, 301 (2003) 1351-1354.

[42] J. Alvarez, R.G. Cooks, S.E. Barlow, D.J. Gaspar, J.H. Futrell, J. Laskin, Preparation and in situ characterization of surfaces using soft landing in a Fourier transform ion cyclotron resonance mass spectrometer, Analytical Chemistry, 77 (2005) 3452-3460.

[43] M. Volny, W.T. Elam, A. Branca, B.D. Ratner, F. Turecek, Preparative soft and reactive landing of multiply charged protein ions on a plasma-treated metal surface, Analytical Chemistry, 77 (2005) 4890 4896.

[44] H.J. Rader, A. Rouhanipour, A.M. Talarico, V. Palermo, P. Samori, K. Mullen, Processing of giant graphene molecules by soft-landing mass spectrometry, Nature Materials, 5 (2006) 276-280.

[45] R.E. Palmer, S. Pratontep, H.G. Boyen, Nanostructured surfaces from size-selected clusters, Nature Materials, 2 (2003) 443-448.

[46] U. Heiz, F. Vanolli, L. Trento, W.D. Schneider, Chemical reactivity of size-selected supported clusters: An experimental setup, Review of Scientific Instruments, 68 (1997) 1986-1994.

[47] S. Vajda, M.J. Pellin, J.P. Greeley, C.L. Marshall, L.A. Curtiss, G.A. Ballentine, J.W. Elam, S. CatillonMucherie, P.C. Redfern, F. Mehmood, P. Zapol, Subnanometre platinum clusters as highly active and selective catalysts for the oxidative dehydrogenation of propane, Nature Materials, 8 (2009) 213-216.

[48] G.E. Johnson, M. Lysonski, J. Laskin, In situ reactivity and TOF-SIMS analysis of surfaces prepared by soft and reactive landing of mass-selected ions, Analytical Chemistry, 82 (2010) 5718-5727.

[49] Z.X. Nie, G.T. Li, M.P. Goodwin, L. Gao, J. Cyriac, R.G. Cooks, In Situ SIMS Analysis and Reactions of Surfaces Prepared by Soft Landing of Mass-Selected Cations and Anions Using an Ion Trap Mass Spectrometer, Journal of the American Society for Mass Spectrometry, 20 (2009) 949-956.

[50] J. Cyriac, M. Wleklinski, G.T. Li, L. Gao, R.G. Cooks, In situ Raman spectroscopy of surfaces modified by ion soft landing, Analyst, 137 (2012) 1363-1369.

[51] M. Volny, A. Sengupta, C.B. Wilson, B.D. Swanson, E.J. Davis, F. Turecek, Surface-enhanced Raman spectroscopy of soft-landed polyatomic ions and molecules, Analytical Chemistry, 79 (2007) 4543-4551. [52] Q.C. Hu, P. Wang, P.L. Gassman, J. Laskin, In situ studies of soft- and reactive landing of massselected ions using infrared reflection absorption spectroscopy, Analytical Chemistry, 81 (2009) 7302 7308.

[53] S. Nagaoka, T. Matsumoto, K. Ikemoto, M. Mitsui, A. Nakajima, Soft-landing isolation of multidecker $\mathrm{V}$-2(benzene)(3) complexes in an organic monolayer matrix: An infrared spectroscopy and thermal desorption study, Journal of the American Chemical Society, 129 (2007) 1528-+.

[54] J.P. Cowin, A.A. Tsekouras, M.J. Iedema, K. Wu, G.B. Ellison, Immobility of protons in ice from 30 to 190 K, Nature, 398 (1999) 405-407.

[55] Z.T. Deng, N. Thontasen, N. Malinowski, G. Rinke, L. Harnau, S. Rauschenbach, K. Kern, A Close Look at Proteins: Submolecular Resolution of Two- and Three-Dimensionally Folded Cytochrome $\mathrm{c}$ at Surfaces, Nano Letters, 12 (2012) 2452-2458.

[56] N. Hauptmann, K. Scheil, T.G. Gopakumar, F.L. Otte, C. Schütt, R. Herges, R. Berndt, Surface Control of Alkyl Chain Conformations and 2D Chiral Amplification, Journal of the American Chemical Society, 135 (2013) 8814-8817.

[57] N. Bajales, S. Schmaus, T. Miyamashi, W. Wulfhekel, J. Wilhelm, M. Walz, M. Stendel, A. Bagrets, F. Evers, S. Ulas, B. Kern, A. Bottcher, M.M. Kappes, $C_{58}$ on $\mathrm{Au}(111)$ : A scanning tunneling microscopy study, Journal of Chemical Physics, 138 (2013) 104703. 
[58] S. Ulas, D. Loffler, P. Weis, A. Bottcher, M.M. Kappes, Desorption of $\mathrm{C}_{60}$ upon thermal decomposition of cesium $C_{58}$ fullerides, Journal of Chemical Physics, 136 (2012) 114708.

[59] G.E. Johnson, C. Wang, T. Priest, J. Laskin, Monodisperse $\mathrm{Au}_{11}$ clusters prepared by soft landing of mass selected ions, Analytical Chemistry, 83 (2011) 8069-8072.

[60] J.L.P. Benesch, B.T. Ruotolo, D.A. Simmons, N.P. Barrera, N. Morgner, L. Wang, H.R. Saibil, C.V. Robinson, Separating and visualising protein assemblies by means of preparative mass spectrometry and microscopy, Journal of Structural Biology, 172 (2010) 161-168.

[61] M.E. Bier, J.W. Amy, R.G. Cooks, J.E.P. Syka, P. Ceja, G. Stafford, A tandem quadrupole massspectrometer for the study of surface-induced dissociation, International Journal of Mass Spectrometry and Ion Processes, 77 (1987) 31-47.

[62] V.H. Wysocki, J.M. Ding, J.L. Jones, J.H. Callahan, F.L. King, Surface-induced dissociation in tandem quadrupole mass spectrometers - a comparison of 3 designs, Journal of the American Society for Mass Spectrometry, 3 (1992) 27-32.

[63] Z. Ouyang, V. Grill, J. Alvarez, C.H. Doerge, L. Gianelli, P. Thomas, H.W. Rohrs, R.G. Cooks, A multiquadrupole tandem mass spectrometer for the study of ion/surface collision processes, Review of Scientific Instruments, 73 (2002) 2375-2391.

[64] M.E. Bier, J.C. Schwartz, K.L. Schey, R.G. Cooks, Tandem mass-spectrometry using an in-line ion surface collision device, International Journal of Mass Spectrometry and Ion Processes, 103 (1990) 1-19. [65] A.S. Galhena, S. Dagan, C.M. Jones, R.L. Beardsley, V.N. Wysocki, Surface-induced dissociation of peptides and protein complexes in a quadrupole/Time-of-Flight mass spectrometer, Analytical Chemistry, 80 (2008) 1425-1436.

[66] K.L. Schey, D.A. Durkin, K.R. Thornburg, Design and performance of an in-line surface-induced dissociation device in a 4-sector mass-spectrometer, Journal of the American Society for Mass Spectrometry, 6 (1995) 257-263.

[67] S.A. Lammert, R.G. Cooks, Surface-induced dissociation of molecular-ions in a quadrupole ion trap mass-spectrometer, Journal of the American Society for Mass Spectrometry, 2 (1991) 487-491.

[68] B.E. Winger, H.J. Laue, S.R. Horning, R.K. Julian, S.A. Lammert, D.E. Riederer, R.G. Cooks, Hybrid BEEQ tandem mass-spectrometer for the study of ion surface collision processes, Review of Scientific Instruments, 63 (1992) 5613-5625.

[69] K. Schey, R.G. Cooks, R. Grix, H. Wollnik, A tandem time-of-flight mass-spectrometer for surfaceinduced dissociation, International Journal of Mass Spectrometry and Ion Processes, 77 (1987) 49-61. [70] L.L. Haney, D.E. Riederer, Delayed extraction for improved resolution of ion/surface collision products by time-of-flight mass spectrometry, Analytica Chimica Acta, 397 (1999) 225-233.

[71] E. Stone, K.J. Gillig, B. Ruotolo, K. Fuhrer, M. Gonin, A. Schultz, D.H. Russell, Surface-induced dissociation on a MALDI-ion mobility-orthogonal time-of-flight mass spectrometer: Sequencing peptides from an "in-solution" protein digest, Analytical Chemistry, 73 (2001) 2233-2238.

[72] C.M. Gamage, F.M. Fernandez, K. Kuppannan, V.H. Wysocki, Submicrosecond surface-induced dissociation of peptide ions in a MALDI TOF MS, Analytical Chemistry, 76 (2004) 5080-5091.

[73] E.N. Nikolaev, A. Somogyi, D.L. Smith, C.G. Gu, V.H. Wysocki, C.D. Martin, G.L. Samuelson, Implementation of low-energy surface-induced dissociation (eV SID) and high-energy collision-induced dissociation (keV CID) in a linear sector-TOF hybrid tandem mass spectrometer, International Journal of Mass Spectrometry, 212 (2001) 535-551.

[74] C.F. Ijames, C.L. Wilkins, Surface-induced dissociation by fourier-transform mass-spectrometry, Analytical Chemistry, 62 (1990) 1295-1299.

[75] J. Laskin, E.V. Denisov, A.K. Shukla, S.E. Barlow, J.H. Futrell, Surface-induced dissociation in a Fourier transform ion cyclotron resonance mass spectrometer: Instrument design and evaluation, Analytical Chemistry, 74 (2002) 3255-3261. 
[76] R.A. Chorush, D.P. Little, S.C. Beu, T.D. Wood, F.W. McLafferty, Surface-induced dissociation of multiply protonated proteins, Analytical Chemistry, 67 (1995) 1042-1046.

[77] W.Q. Zhong, E.N. Nikolaev, J.H. Futrell, V.H. Wysocki, Tandem Fourier transform mass spectrometry studies of surface-induced dissociation of benzene monomer and dimer ions on a self-assembled fluorinated alkanethiolate monolayer surface, Analytical Chemistry, 69 (1997) 2496-2503.

[78] V.S. Rakov, J.H. Futrell, E.V. Denisov, E.N. Nikolaev, Instrumentation of kinetic energy-resolved surface-induced dissociation in Fourier transform mass spectrometry, European Journal of Mass Spectrometry, 6 (2000) 299-317.

[79] W.J. Sun, J.C. May, D.H. Russell, A novel surface-induced dissociation instrument for ion mobilitytime-of-flight mass spectrometry, International Journal of Mass Spectrometry, 259 (2007) 79-86. [80] W.J. Sun, J.C. May, K.J. Gillig, D.H. Russell, A dual time-of-flight apparatus for an ion mobilitysurface-induced dissociation-mass spectrometer for high-throughput peptide sequencing, International Journal of Mass Spectrometry, 287 (2009) 39-45.

[81] M.W. Zhou, C.S. Huang, V.H. Wysocki, Surface-Induced Dissociation of Ion Mobility-Separated Noncovalent Complexes in a Quadrupole/Time-of-Flight Mass Spectrometer, Analytical Chemistry, 84 (2012) 6016-6023.

[82] A. Budrevich, B. Tsipinyuk, A. Bekkerman, E. Kolodney, Surface scattering of hyperthermal (10-50 $\mathrm{eV)}$ neutral $C_{60}$ : Angular and energy distributions, Journal of Chemical Physics, 106 (1997) 5771-5774. [83] J. Kubista, Z. Dolejsek, Z. Herman, Energy partitioning in collisions of slow polyatomic ions with surfaces: ethanol molecular ions on stainless steel surfaces, European Mass Spectrometry, 4 (1998) 311319.

[84] R. Worgotter, J. Kubista, J. Zabka, Z. Dolejsek, T.D. Mark, Z. Herman, Surface-induced reactions and decomposition of the benzene molecular ion $\mathrm{C} 6 \mathrm{H} 6+$ : Product ion intensities, angular and translational energy distributions, International Journal of Mass Spectrometry, 174 (1998) 53-62.

[85] H.L. de Clercq, A.D. Sen, A.K. Shukla, J.H. Futrell, Inelastic ion-surface collisions: scattering and dissociation of low energy benzene molecular cations, International Journal of Mass Spectrometry, 212 (2001) 491-504.

[86] A.K. Shukla, J.H. Futrell, A beam scattering instrument for the dynamics studies of surface-induced dissociation processes, Review of Scientific Instruments, 74 (2003) 168-175.

[87] B.E. Winger, R.K. Julian, R.G. Cooks, C.E.D. Chidsey, Surface-reactions and surface-induced dissociation of polyatomic ions at self-assembled organic monolayer surfaces, Journal of the American Chemical Society, 113 (1991) 8967-8969.

[88] V.H. Wysocki, J.L. Jones, J.M. Ding, Polyatomic ion/surface collisions at self-assembled monolayers films, Journal of the American Chemical Society, 113 (1991) 8969-8970.

[89] J. Laskin, J.H. Futrell, Energy transfer in collisions of peptide ions with surfaces, Journal of Chemical Physics, 119 (2003) 3413-3420.

[90] U. Heiz, E.L. Bullock, Fundamental aspects of catalysis on supported metal clusters, Journal of Materials Chemistry, 14 (2004) 564-577.

[91] D.-C. Lim, C.-C. Hwang, G. Gantefor, Y.D. Kim, Model catalysts of supported Au nanoparticles and mass-selected clusters, Physical Chemistry Chemical Physics, 12 (2010) 15172-15180.

[92] Z. Herman, Collisions of slow polyatomic ions with surfaces: The scattering method and results, Journal of the American Society for Mass Spectrometry, 14 (2003) 1360-1372.

[93] K.Y. Song, O. Meroueh, W.L. Hase, Dynamics of $\mathrm{Cr}(\mathrm{CO})_{6}{ }^{+}$collisions with hydrogenated surfaces, Journal of Chemical Physics, 118 (2003) 2893-2902.

[94] J. Kubišta, Z. Dolejšek, Z. Herman, Energy partitioning in collisions of slow polyatomic ions with surfaces: ethanol molecular ions on stainless steel surfaces, European Journal of Mass Spectrometry, 4 (1998) 311-319. 
[95] R. Wörgötter, J. Kubišta, J. Žabka, Z. Dolejšek, T.D. Märk, Z. Herman, Surface-induced reactions and decomposition of the benzene molecular ion $\mathrm{C}_{6} \mathrm{H}_{6}{ }^{+}$: Product ion intensities, angular and translational energy distributions, International Journal of Mass Spectrometry and Ion Processes, 174 (1998) 53-62. [96] J. Roithova, J. Zabka, Z. Dolejsek, Z. Herman, Collisions of slow polyatomic ions with surfaces: Dissociation and chemical reactions of $\mathrm{CD}_{5}{ }^{+}, \mathrm{CD}_{4}{ }^{+}, \mathrm{CD}_{3}{ }^{+}$, and their isotopic variants on room-temperature and heated carbon surfaces, Journal of Physical Chemistry B, 106 (2002) 8293-8301.

[97] A.K. Shukla, J.H. Futrell, Dynamics of hyperthermal energy ion-surface collisions: dissociative and non-dissociative scattering of ethanol cations from a self-assembled monolayer surface of fluorinated alkyl thiol on Au(111), International Journal of Mass Spectrometry, 223 (2003) 783-801.

[98] A.K. Shukla, J.H. Futrell, A.D. Sen, Dynamics of the dissociative and nondissociative scattering of hyperthermal $\mathrm{CS}_{2}{ }^{+}$from a self-assembled fluoroalkyl monolayer surface on gold substrate, Journal of Chemical Physics, 118 (2003) 11217-11225.

[99] J.W. Shen, Y.H. Yim, B.B. Feng, V. Grill, C. Evans, R.G. Cooks, Soft landing of ions onto self-assembled hydrocarbon and fluorocarbon monolayer surfaces, International Journal of Mass Spectrometry, 183 (1999) 423-435.

[100] D.L. Smith, V.H. Wysocki, R. Colorado, O.E. Shmakova, M. Graupe, T.R. Lee, Low-energy ion-surface collisions characterize alkyland fluoroalkyl-terminated self-assembled monolayers on gold, Langmuir, 18 (2002) 3895-3902.

[101] J. Zabka, Z. Dolejsek, Z. Herman, Energy partitioning in collisions of slow polyatomic ions with surfaces: Ethanol molecular ions on surfaces covered by self-assembled monolayers (CF-SAM, CH-SAM, COOH-SAM), Journal of Physical Chemistry A, 106 (2002) 10861-10869.

[102] J. Laskin, E. Denisov, J. Futrell, A comparative study of collision-induced and surface-induced dissociation. 1. Fragmentation of protonated dialanine, Journal of the American Chemical Society, 122 (2000) 9703-9714.

[103] O. Meroueh, W.L. Hase, Dynamics of energy transfer in peptide-surface collisions, Journal of the American Chemical Society, 124 (2002) 1524-1531.

[104] S.B.M. Bosio, W.L. Hase, Simulations of energy transfer in $\mathrm{Cr}(\mathrm{CO})_{6}{ }^{+}$surface-induced dissociation, International Journal of Mass Spectrometry, 174 (1998) 1-9.

[105] O. Meroueh, W.L. Hase, Energy transfer pathways in the collisional activation of peptides, International Journal of Mass Spectrometry, 201 (2000) 233-244.

[106] J.P. Wang, S.O. Meroueh, Y.F. Wang, W.L. Hase, Efficiency of energy transfer in protonated diglycine and dialanine SID - Effects of collision angle, peptide ion size, and intramolecular potential, International Journal of Mass Spectrometry, 230 (2003) 57-64.

[107] A. Rahaman, W.L. Hase, K. Song, J. Wang, O. Meroueh, Chemical Dynamics Simulations of Energy Transfer and Unimolecular Decomposition in Collision-Induced Dissociation (CID) and Surface-Induced Dissociation (SID), in: J. Laskin, C. Lifshitz (Eds.) Principles of Mass Spectrometry Applied to Biomolecules, John Wiley \& Sons., Inc., Hoboken, NJ, 2006.

[108] G.L. Barnes, W.L. Hase, Energy Transfer, Unfolding, and Fragmentation Dynamics in Collisions of NProtonated Octaglycine with an H-SAM Surface, Journal of the American Chemical Society, 131 (2009) 17185-17193.

[109] L. Yang, O.A. Mazyar, U. Lourderaj, J.P. Wang, M.T. Rodgers, E. Martinez-Nunez, S.V. Addepalli, W.L. Hase, Chemical dynamics simulations of energy transfer in collisions of protonated peptide-ions with a perfluorinated alkylthiol self-assembled monolayer surface, Journal of Physical Chemistry C, 112 (2008) 9377-9386.

[110] J. Laskin, T.H. Bailey, E.V. Denisov, J.H. Futrell, On the relative stability of singly protonated des$\mathrm{Arg}^{1-}$ and des-Arg ${ }^{9}$-bradykinins, Journal of Physical Chemistry A, 106 (2002) 9832-9836.

[111] J. Laskin, J.H. Futrell, On the efficiency of energy transfer in collisional activation of small peptides, Journal of Chemical Physics, 116 (2002) 4302-4310. 
[112] K. Vekey, A. Somogyi, V.H. Wysocki, Internal energy-distribution of benzene molecular-ions in surface-induced dissociation, Journal of Mass Spectrometry, 30 (1995) 212-217.

[113] S.O. Meroueh, Y.F. Wang, W.L. Hase, Direct dynamics Simulations of collision- and surface-induced dissociation of N-protonated glycine. Shattering fragmentation, Journal of Physical Chemistry A, 106 (2002) 9983-9992.

[114] K. Park, B. Deb, K. Song, W.L. Hase, Importance of Shattering Fragmentation in the SurfaceInduced Dissociation of Protonated Octaglycine, Journal of the American Society for Mass Spectrometry, 20 (2009) 939-948.

[115] J. Laskin, J.H. Futrell, Surface-induced dissociation of peptide ions: Kinetics and dynamics, Journal of the American Society for Mass Spectrometry, 14 (2003) 1340-1347.

[116] J. Laskin, K.M. Beck, J.J. Hache, J.H. Futrell, Surface-induced dissociation of ions produced by matrix-assisted laser desorption/ionization in a Fourier transform ion cyclotron resonance mass spectrometer, Analytical Chemistry, 76 (2004) 351-356.

[117] F.M. Fernandez, V.H. Wysocki, J.H. Futrell, J. Laskin, Protein identification via surface-induced dissociation in an FT-ICR mass spectrometer and a patchwork sequencing approach, Journal of the American Society for Mass Spectrometry, 17 (2006) 700-709.

[118] J.L. Jones, A.R. Dongre, A. Somogyi, V.H. Wysocki, Sequence dependence of peptide fragmentation efficiency curves determined by electrospray-ionization surface-induced dissociation massspectrometry, Journal of the American Chemical Society, 116 (1994) 8368-8369.

[119] G. Tsaprailis, H. Nair, A. Somogyi, V.H. Wysocki, W.Q. Zhong, J.H. Futrell, S.G. Summerfield, S.J. Gaskell, Influence of secondary structure on the fragmentation of protonated peptides, Journal of the American Chemical Society, 121 (1999) 5142-5154.

[120] H. Nair, V.H. Wysocki, Are peptides without basic residues protonated primarily at the amino terminus?, International Journal of Mass Spectrometry, 174 (1998) 95-100.

[121] V.H. Wysocki, G. Tsaprailis, L.L. Smith, L.A. Breci, Special feature: Commentary - Mobile and localized protons: a framework for understanding peptide dissociation, Journal of Mass Spectrometry, 35 (2000) 1399-1406.

[122] C.G. Gu, G. Tsaprailis, L. Breci, V.H. Wysocki, Selective gas-phase cleavage at the peptide bond terminal to aspartic acid in fixed-charge derivatives of asp-containing peptides, Analytical Chemistry, 72 (2000) 5804-5813.

[123] G. Tsaprailis, A. Somogyi, E.N. Nikolaev, V.H. Wysocki, Refining the model for selective cleavage at acidic residues in arginine-containing protonated peptides, International Journal of Mass Spectrometry, 195 (2000) 467-479.

[124] Y.Y. Huang, V.H. Wysocki, D.L. Tabb, J.R. Yates, The influence of histidine on cleavage C-terminal to acidic residues in doubly protonated tryptic peptides, International Journal of Mass Spectrometry, 219 (2002) 233-244.

[125] J. Laskin, T.H. Bailey, J.H. Futrell, Mechanisms of peptide fragmentation from time- and energyresolved surface-induced dissociation studies: Dissociation of angiotensin analogs, International Journal of Mass Spectrometry, 249 (2006) 462-472.

[126] J.M. Spraggins, J.A. Lloyd, M.V. Johnston, J. Laskin, D.P. Ridge, Fragmentation mechanisms of oxidized peptides elucidated by SID, RRKM modeling, and molecular dynamics, Journal of the American Society for Mass Spectrometry, 20 (2009) 1579-1592.

[127] J. Laskin, Z.B. Yang, T. Song, C. Lam, I.K. Chu, Effect of the basic residue on the energetics, dynamics, and mechanisms of gas-phase fragmentation of protonated peptides, Journal of the American Chemical Society, 132 (2010) 16006-16016.

[128] T.H. Bailey, J. Laskin, J.H. Futrell, Energetics of selective cleavage at acidic residues studied by timeand energy-resolved surface-induced dissociation in FT-ICR MS, International Journal of Mass Spectrometry, 222 (2003) 313-327. 
[129] J. Laskin, T.H. Bailey, J.H. Futrell, Fragmentation energetics for angiotensin II and its analogs from time-and energy-resolved surface-induced dissociation studies, International Journal of Mass Spectrometry, 234 (2004) 89-99.

[130] J. Laskin, Energy and entropy effects in the gas phase dissociation of peptides and proteins, in: J. Laskin, C. Lifshitz (Eds.) Principles of Mass Spectrometry Applied to Biomolecules, John Wiley \& Sons., Inc., Hoboken, NJ, 2006.

[131] J. Laskin, Energetics and dynamics of fragmentation of protonated leucine enkephalin from timeand energy-resolved surface-induced dissociation studies, Journal of Physical Chemistry A, 110 (2006) 8554-8562.

[132] J. Laskin, M. Byrd, J. Futrell, Internal energy distributions resulting from sustained off-resonance excitation in $\mathrm{ftms}$. I. Fragmentation of the bromobenzene radical cation, International Journal of Mass Spectrometry, 195 (2000) 285-302.

[133] J. Laskin, J. Futrell, Internal energy distributions resulting from sustained off-resonance excitation in fourier transform ion cyclotron resonance mass spectrometry. li. Fragmentation of the 1bromonaphthalene radical cation, Journal of Physical Chemistry A, 104 (2000) 5484-5494.

[134] H. Lioe, J. Laskin, G.E. Reid, R.A.J. O'Hair, Energetics and dynamics of the fragmentation reactions of protonated peptides containing methionine sulfoxide or aspartic acid via energy- and time-resolved surface induced dissociation, Journal of Physical Chemistry A, 111 (2007) 10580-10588.

[135] I.K. Chu, J. Laskin, Review formation of peptide radical ions through dissociative electron transfer in ternary metal-ligand-peptide complexes, European Journal of Mass Spectrometry, 17 (2011) 543-556. [136] J. Laskin, Z. Yang, I.K. Chu, Energetics and dynamics of electron transfer and proton transfer in dissociation of metal'"(salen)-peptide complexes in the gas phase, Journal of the American Chemical Society, 130 (2008) 3218-3230.

[137] J. Laskin, J.H. Futrell, I.K. Chu, Is dissociation of peptide radical cations an ergodic process?, Journal of the American Chemical Society, 129 (2007) 9598-+.

[138] Z.B. Yang, C. Lam, I.K. Chu, J. Laskin, The effect of the secondary structure on dissociation of peptide radical cations: Fragmentation of angiotensin III and its analogues, Journal of Physical Chemistry B, 112 (2008) 12468-12478.

[139] J. Laskin, Z.B. Yang, C. Lam, I.K. Chu, Energy and entropy effects in dissociation of peptide radical anions, International Journal of Mass Spectrometry, 316 (2012) 251-258.

[140] J.C. Jurchen, E.R. Williams, Origin of asymmetric charge partitioning in the dissociation of gasphase protein homodimers, Journal of the American Chemical Society, 125 (2003) 2817-2826.

[141] C.M. Jones, R.L. Beardsley, A.S. Galhena, S. Dagan, G.L. Cheng, V.H. Wysocki, Symmetrical gasphase dissociation of noncovalent protein complexes via surface collisions, Journal of the American Chemical Society, 128 (2006) 15044-15045.

[142] A.E. Blackwell, E.D. Dodds, V. Bandarian, V.H. Wysocki, Revealing the Quaternary Structure of a Heterogeneous Noncovalent Protein Complex through Surface-Induced Dissociation, Analytical Chemistry, 83 (2011) 2862-2865.

[143] E.D. Dodds, A.E. Blackwell, C.M. Jones, K.L. Holso, D.J. O'Brien, M.H.J. Cordes, V.H. Wysocki, Determinants of Gas-Phase Disassembly Behavior in Homodimeric Protein Complexes with Related Yet Divergent Structures, Analytical Chemistry, 83 (2011) 3881-3889.

[144] M.W. Zhou, S. Dagan, V.H. Wysocki, Protein Subunits Released by Surface Collisions of Noncovalent Complexes: Nativelike Compact Structures Revealed by Ion Mobility Mass Spectrometry, Angewandte Chemie-International Edition, 51 (2012) 4336-4339.

[145] M.W. Zhou, S. Dagan, V.H. Wysocki, Impact of charge state on gas-phase behaviors of noncovalent protein complexes in collision induced dissociation and surface induced dissociation, Analyst, 138 (2013) 1353-1362. 
[146] M.W. Zhou, C.M. Jones, V.H. Wysocki, Dissecting the Large Noncovalent Protein Complex GroEL with Surface-Induced Dissociation and Ion Mobility Mass Spectrometry, Analytical Chemistry, 85 (2013) 8262-8267.

[147] A.K. Badu-Tawiah, J. Cyriac, R.G. Cooks, Reactions of Organic lons at Ambient Surfaces in a SolventFree Environment, Journal of the American Society for Mass Spectrometry, 23 (2012) 842-849.

[148] A.K. Badu-Tawiah, C.P. Wu, R.G. Cooks, Ambient lon Soft Landing, Analytical Chemistry, 83 (2011) 2648-2654.

[149] J.W. Shen, C. Evans, N. Wade, R.G. Cooks, Ion-ion collisions leading to formation of C-C bonds at surfaces: An interfacial Kolbe reaction, Journal of the American Chemical Society, 121 (1999) 9762-9763. [150] J. Alvarez, J.H. Futrell, J. Laskin, Soft-landing of peptides onto self-assembled monolayer surfaces, Journal of Physical Chemistry A, 110 (2006) 1678-1687.

[151] M.B.J. Wijesundara, Y. Ji, B. Ni, S.B. Sinnott, L. Hanley, Effect of polyatomic ion structure on thinfilm growth: Experiments and molecular dynamics simulations, Journal of Applied Physics, 88 (2000) 5004-5016.

[152] N. Wade, C. Evans, S.C. Jo, R.G. Cooks, Silylation of an OH-terminated self-assembled monolayer surface through low-energy collisions of ions: a novel route to synthesis and patterning of surfaces, Journal of Mass Spectrometry, 37 (2002) 591-602.

[153] N. Wade, B. Gologan, A. Vincze, R.G. Cooks, D.M. Sullivan, M.L. Bruening, Esterification and ether formation at a hydroxyl-terminated self-assembled monolayer surface using low-energy collisions of polyatomic cations, Langmuir, 18 (2002) 4799-4808.

[154] P. Wang, O. Hadjar, J. Laskin, Covalent immobilization of peptides on self-assembled monolayer surfaces using soft-landing of mass-selected ions, Journal of the American Chemical Society, 129 (2007) 8682-8683.

[155] P. Wang, O. Hadjar, P.L. Gassman, J. Laskin, Reactive landing of peptide ions on self-assembled monolayer surfaces: an alternative approach for covalent immobilization of peptides on surfaces, Physical Chemistry Chemical Physics, 10 (2008) 1512-1522.

[156] Q.C. Hu, J. Laskin, Reactive landing of dendrimer ions onto activated self-assembled monolayer surfaces, Journal of Physical Chemistry C, (2014).

[157] S. Nagaoka, K. Ikemoto, K. Horiuchi, A. Nakajima, Soft- and Reactive-Landing of $\mathrm{Cr}(\text { aniline })_{2}$ Sandwich Complexes onto Self-Assembled Monolayers: Separation between Functional and Binding Sites, Journal of the American Chemical Society, 133 (2011) 18719-18727.

[158] M. Volny, W.T. Elam, B.D. Ratner, F. Turecek, Preparative soft and reactive landing of gas-phase ions on plasma-treated metal surfaces, Analytical Chemistry, 77 (2005) 4846-4853.

[159] G.E. Johnson, J. Laskin, Preparation of Surface Organometallic Catalysts by Gas-Phase Ligand Stripping and Reactive Landing of Mass-Selected lons, Chemistry - A European Journal, 16 (2010) 1443314438.

[160] M. Mitsui, S. Nagaoka, T. Matsumoto, A. Nakajima, Soft-landing isolation of vanadium-benzene sandwich clusters on a room-temperature substrate using $n$-alkanethiolate self-assembled monolayer matrixes, Journal of Physical Chemistry B, 110 (2006) 2968-2971.

[161] S. Nagaoka, K. Ikemoto, K. Horiuchi, A. Nakajima, Soft- and Reactive-Landing of Cr(aniline)(2) Sandwich Complexes onto Self-Assembled Monolayers: Separation between Functional and Binding Sites, Journal of the American Chemical Society, 133 (2011) 18719-18727.

[162] J. Laskin, P. Wang, O. Hadjar, Soft-landing of Co"'(salen) ${ }^{+}$and MnIII(salen) ${ }^{+}$on self-assembled monolayer surfaces, Journal of Physical Chemistry C, 114 (2010) 5305-5311.

[163] N. Thontasen, G. Levita, N. Malinowski, Z. Deng, S. Rauschenbach, K. Kern, Grafting Crown Ether Alkali Host-Guest Complexes at Surfaces by Electrospray Ion Beam Deposition, Journal of Physical Chemistry C, 114 (2010) 17768-17772. 
[164] L. Hanley, H.J. Lim, D.G. Schultz, S.B. Wainhaus, P. deSainteClaire, W.L. Hase, Surface energy transfer by low energy polyatomic ion collisions, Nuclear Instruments \& Methods in Physics Research Section B-Beam Interactions with Materials and Atoms, 125 (1997) 218-222.

[165] S.C. Nanita, Z. Takats, R.G. Cooks, S. Myung, D.E. Clemmer, Chiral enrichment of serine via formation, dissociation, and soft-landing of octameric cluster ions, Journal of the American Society for Mass Spectrometry, 15 (2004) 1360-1365.

[166] B. Wang, B. Yoon, M. Konig, Y. Fukamori, F. Esch, U. Heiz, U. Landman, Size-Selected Monodisperse Nanoclusters on Supported Graphene: Bonding, Isomerism, and Mobility, Nano Letters, 12 (2012) 59075912.

[167] B. Yoon, H. Hakkinen, U. Landman, A.S. Worz, J.M. Antonietti, S. Abbet, K. Judai, U. Heiz, Charging effects on bonding and catalyzed oxidation of $\mathrm{CO}$ on $\mathrm{Au}_{8}$ clusters on MgO, Science, 307 (2005) 403-407. [168] G. Kwon, G.A. Ferguson, C.J. Heard, E.C. Tyo, C.R. Yin, J. DeBartolo, S. Seifert, R.E. Winans, A.J. Kropf, J. Greeley, R.L. Johnston, L.A. Curtiss, M.J. Pellin, S. Vajda, Size-Dependent Subnanometer Pd Cluster $\left(\mathrm{Pd}_{4}, \mathrm{Pd}_{6}\right.$, and $\left.\mathrm{Pd}_{17}\right)$ Water Oxidation Electrocatalysis, Acs Nano, 7 (2013) 5808-5817.

[169] Y. Lei, F. Mehmood, S. Lee, J. Greeley, B. Lee, S. Seifert, R.E. Winans, J.W. Elam, R.J. Meyer, P.C. Redfern, D. Teschner, R. Schlogl, M.J. Pellin, L.A. Curtiss, S. Vajda, Increased Silver Activity for Direct Propylene Epoxidation via Subnanometer Size Effects, Science, 328 (2010) 224-228.

[170] B. Gologan, Z. Takats, J. Alvarez, J.M. Wiseman, N. Talaty, Z. Ouyang, R.G. Cooks, lon soft-landing into liquids: Protein identification, separation, and purification with retention of biological activity, Journal of the American Society for Mass Spectrometry, 15 (2004) 1874-1884.

[171] P. Wang, J. Laskin, Helical peptide arrays on self-assembled monolayer surfaces through soft and reactive landing of mass-selected ions, Angewandte Chemie-International Edition, 47 (2008) 6678-6680. [172] B.B. Feng, D.S. Wunschel, C.D. Masselon, L. Pasa-Tolic, R.D. Smith, Retrieval of DNA using softlanding after mass analysis by ESI-FTICR for enzymatic manipulation, Journal of the American Chemical Society, 121 (1999) 8961-8962.

[173] G. Siuzdak, B. Bothner, M. Yeager, C. Brugidou, C.M. Fauquet, K. Hoey, C.M. Chang, Mass spectrometry and viral analysis, Chemistry \& Biology, 3 (1996) 45-48.

[174] D. Loffler, S.S. Jester, P. Weis, A. Bottcher, M.M. Kappes, $C_{n}$ films ( $n=50,52,54,56$, and 58 ) on graphite: Cage size dependent electronic properties, Journal of Chemical Physics, 124 (2006) 054705. [175] D. Loffler, S. Ulas, S.S. Jester, P. Weis, A. Bottcher, M.M. Kappes, Properties of non-IPR fullerene films versus size of the building blocks, Physical Chemistry Chemical Physics, 12 (2010) 10671-10684. [176] S. Ulas, D. Strelnikov, P. Weis, A. Bottcher, M.M. Kappes, Incorporating $C_{2}$ into $C_{60}$ films, Journal of Chemical Physics, 136 (2012) 014701.

[177] G.R. Blacken, M. Volny, T. Vaisar, M. Sadılek, F. Turecek, In Situ Enrichment of Phosphopeptides on MALDI Plates Functionalized by Reactive Landing of Zirconium(IV)-n-Propoxide lons, Analytical Chemistry, 79 (2007) 5449-5456.

[178] W. Hoffmann, G. Verbeck, Toward a Reusable Surface-Enhanced Raman Spectroscopy (SERS) Substrate by Soft-Landing Ion Mobility, Appl. Spectrosc., 67 (2013) 656-660.

[179] A.A. Tsekouras, M.J. ledema, J.P. Cowin, Soft-landed ion diffusion studies on vapor-deposited hydrocarbon films, Journal of Chemical Physics, 111 (1999) 2222-2234.

[180] W.P. Peng, G.E. Johnson, I.C. Fortmeyer, P. Wang, O. Hadjar, R.G. Cooks, J. Laskin, Redox chemistry in thin layers of organometallic complexes prepared using ion soft landing, Physical Chemistry Chemical Physics, 13 (2011) 267-275.

[181] N. Hauptmann, C. Hamann, H. Tang, R. Berndt, Switching and charging of a ruthenium dye on $\mathrm{Ag}(111)$, Physical Chemistry Chemical Physics, 15 (2013) 10326-10330.

[182] Q.C. Hu, P. Wang, J. Laskin, Effect of the surface on the secondary structure of soft landed peptide ions, Physical Chemistry Chemical Physics, 12 (2010) 12802-12810. 
[183] S. Kahle, Z.T. Deng, N. Malinowski, C. Tonnoir, A. Forment-Aliaga, N. Thontasen, G. Rinke, D. Le, V. Turkowski, T.S. Rahman, S. Rauschenbach, M. Ternes, K. Kern, The Quantum Magnetism of Individual Manganese-12-Acetate Molecular Magnets Anchored at Surfaces, Nano Letters, 12 (2012) 518-521. [184] O. Hadjar, J.H. Futrell, J. Laskin, First observation of charge reduction and desorption kinetics of multiply protonated peptides soft landed onto self-assembled monolayer surfaces, Journal of Physical Chemistry C, 111 (2007) 18220-18225.

[185] G.L. Barnes, K. Young, L. Yang, W.L. Hase, Fragmentation and reactivity in collisions of protonated diglycine with chemically modified perfluorinated alkylthiolate-self-assembled monolayer surfaces, Journal of Chemical Physics, 134 (2011) 094106.

[186] J. Laskin, P. Wang, O. Hadjar, J.H. Futrell, J. Alvarez, Z.G. Cooks, Charge retention by peptide ions soft-landed onto self-assembled monolayer surfaces, International Journal of Mass Spectrometry, 265 (2007) 237-243.

[187] G.E. Johnson, T. Priest, J. Laskin, Charge retention by gold clusters on surfaces prepared using soft landing of mass selected ions, ACS Nano, 6 (2012) 573-582.

[188] G.E. Johnson, T. Priest, J. Laskin, Coverage-dependent charge reduction of cationic gold clusters on surfaces prepared using soft landing of mass-selected ions, Journal of Physical Chemistry C, 116 (2012) 24977-24986.

[1] J.J. Thomson, Rays of positive electricity and their application to chemical analyses, Longmans, Green and Co., London, New York, 1913.

[2] V. Franchetti, B.H. Solka, W.E. Baitinger, J.W. Amy, R.G. Cooks, Soft Landing of lons as a Means of Surface Modification, International Journal of Mass Spectrometry and Ion Processes, 23 (1977) 29-35.

[3] M.D.A. Mabud, M.J. Dekrey, R.G. Cooks, Surface-induced dissociation of molecular ions, International Journal of Mass Spectrometry and Ion Processes, 67 (1985) 285-294.

[4] A.R. Dongre, A. Somogyi, V.H. Wysocki, Surface-induced dissociation: An effective tool to probe structure, energetics and fragmentation mechanisms of protonated peptides, Journal of Mass Spectrometry, 31 (1996) 339-350.

[5] A.R. Dongre, J.L. Jones, A. Somogyi, V.H. Wysocki, Influence of peptide composition, gas-phase basicity, and chemical modification on fragmentation efficiency: Evidence for the mobile proton model, Journal of the American Chemical Society, 118 (1996) 8365-8374.

[6] V. Grill, J. Shen, C. Evans, R.G. Cooks, Collisions of ions with surfaces at chemically relevant energies: Instrumentation and phenomena, Review of Scientific Instruments, 72 (2001) 3149-3179.

[7] B. Gologan, J.M. Wiseman, R.G. Cooks, lon Soft Landing: Instrumentation, Phenomena, and Applications, in: J. Laskin, C. Lifshitz (Eds.) Principles of Mass Spectrometry Applied to Biomolecules, John Wiley \& Sons., Inc., Hoboken, NJ, 2006.

[8] J. Cyriac, T. Pradeep, H. Kang, R. Souda, R.G. Cooks, Low-Energy lonic Collisions at Molecular Solids, Chemical Reviews, 112 (2012) 5356-5411.

[9] J. Laskin, P. Wang, O. Hadjar, Soft-landing of peptide ions onto self-assembled monolayer surfaces: an overview, Physical Chemistry Chemical Physics, 10 (2008) 1079-1090.

[10] G.E. Johnson, Q.C. Hu, J. Laskin, Soft Landing of Complex Molecules on Surfaces, Annual Review of Analytical Chemistry, 4 (2011) 83-104.

[11] G. Verbeck, W. Hoffmann, B. Walton, Soft-landing preparative mass spectrometry, Analyst, 137 (2012) 4393-4407.

[12] V.H. Wysocki, K.E. Joyce, C.M. Jones, R.L. Beardsley, Surface-induced dissociation of small molecules, peptides, and non-covalent protein complexes, Journal of the American Society for Mass Spectrometry, 19 (2008) 190-208.

[13] R.G. Cooks, T. Ast, A. Mabud, Collisions of polyatomic ions with surfaces, International Journal of Mass Spectrometry, 100 (1990) 209-265. 
[14] R.G. Cooks, T. Ast, T. Pradeep, V. Wysocki, Reactions of ions with organic surfaces, Accounts of Chemical Research, 27 (1994) 316-323.

[15] P. Wang, J. Laskin, Surface Modification Using Reactive Landing of Mass-Selected lons, in: R. Hellborg, H.J. Whitlow, Y. Zhang (Eds.) Ion Beams in Nanoscience and Technology, Springer, London, New York, 2009.

[16] T. Raz, R.D. Levine, On the shattering of clusters by surface impact heating, Journal of Chemical Physics, 105 (1996) 8097-8102.

[17] W. Christen, U. Even, T. Raz, R.D. Levine, Collisional energy loss in cluster surface impact: Experimental, model, and simulation studies of some relevant factors, Journal of Chemical Physics, 108 (1998) 10262-10273.

[18] W. Christen, U. Even, Cluster impact chemistry, Journal of Physical Chemistry A, 102 (1998) 94209426.

[19] R.D. Beck, C. Warth, K. May, M.M. Kappes, Surface impact induced shattering of $C_{60}$. Detection of small $C_{m}$ fragments by negative surface ionization, Chemical Physics Letters, 257 (1996) 557-562.

[20] O. Meroueh, W.L. Hase, Effect of surface stiffness on the efficiency of surface-induced dissociation, Physical Chemistry Chemical Physics, 3 (2001) 2306-2314.

[21] J. Laskin, T.H. Bailey, J.H. Futrell, Shattering of peptide ions on self-assembled monolayer surfaces, Journal of the American Chemical Society, 125 (2003) 1625-1632.

[22] T. Ast, D.E. Riederer, S.A. Miller, M. Morris, R.G. Cooks, Collisions of fluorocarbon ions at solidsurfaces - electronic excitation, surface-induced dissociation and chemical sputtering, Organic Mass Spectrometry, 28 (1993) 1021-1033.

[23] C. Xirouchaki, R.E. Palmer, Pinning and implantation of size-selected metal clusters: a topical review, Vacuum, 66 (2002) 167-173.

[24] N. Winograd, B.J. Garrison, Biological Cluster Mass Spectrometry, Annual Review of Physical Chemistry, 61 (2010) 305-322.

[25] R.J. Day, S.E. Unger, R.G. Cooks, Molecular secondary ion mass-spectrometry, Analytical Chemistry, 52 (1980) A557-\&.

[26] A. Benninghoven, Chemical-analysis of inorganic and organic-surfaces and thin-films by static timeof-flight secondary-ion mass-spectrometry (TOF-SIMS), Angew. Chem.-Int. Edit. Engl., 33 (1994) 10231043.

[27] L. Hanley, S.B. Sinnott, The growth and modification of materials via ion-surface processing, Surface Science, 500 (2002) 500-522.

[28] D.C. Jacobs, Reactive collisions of hyperthermal energy molecular ions with solid surfaces, Annual Review of Physical Chemistry, 53 (2002) 379-407.

[29] B. Gologan, J.R. Green, J. Alvarez, J. Laskin, R.G. Cooks, lon/surface reactions and ion soft-landing, Physical Chemistry Chemical Physics, 7 (2005) 1490-1500.

[30] R.W. Gurney, The scattering of positive ions from a platinum surface, Phys. Rev., 32 (1928) 04670477.

[31] C.C. Van Voorhis, K.T. Compton, Accommodation coefficients of positive ions of argon, neon and helium, Phys. Rev., 37 (1931) 1596-1610.

[32] K.S. Woodcock, The emission of negative ions under the bombardment of positive ions, Phys. Rev., 38 (1931) 1696-1703.

[33] R.E. Honig, The development of secondary ion mass-spectrometry (SIMS) - A retrospective, International Journal of Mass Spectrometry and lon Processes, 66 (1985) 31-54.

[34] J.H. Beynon, A.E. Fontaine, G.R. Lester, An anomalous metastable peak in mass spectrum of methanol, Chem. Commun., (1968) 265-\&.

[35] R.G. Cooks, Metastable ions, Elsevier Scientific Pub. Co., 1973. 
[36] C. Lifshitz, M. Shapiro, Sternber.R, Isotope effects on metastable transitions .4. Isotopic methanols, Isr. J. Chem., 7 (1969) 391-\&.

[37] R.G. Cooks, T. Ast, J.H. Beynon, Anomalous metastable peaks, International Journal of Mass Spectrometry and lon Processes, 16 (1975) 348-352.

[38] R.G. Cooks, D.T. Terwilliger, T. Ast, J.H. Beynon, T. Keough, Surface modified mass-spectrometry, Journal of the American Chemical Society, 97 (1975) 1583-1585.

[39] S.A. Miller, H. Luo, S.J. Pachuta, R.G. Cooks, Soft-landing of polyatomic ions at fluorinated selfassembled monolayer surfaces, Science, 275 (1997) 1447-1450.

[40] A. Bottcher, P. Weis, S.S. Jester, D. Loffler, A. Bihlmeier, W. Klopper, M.M. Kappes, Solid C 58 films, Physical Chemistry Chemical Physics, 7 (2005) 2816-2820.

[41] Z. Ouyang, Z. Takats, T.A. Blake, B. Gologan, A.J. Guymon, J.M. Wiseman, J.C. Oliver, V.J. Davisson, R.G. Cooks, Preparing protein microarrays by soft-landing of mass-selected ions, Science, 301 (2003) 1351-1354.

[42] J. Alvarez, R.G. Cooks, S.E. Barlow, D.J. Gaspar, J.H. Futrell, J. Laskin, Preparation and in situ characterization of surfaces using soft landing in a Fourier transform ion cyclotron resonance mass spectrometer, Analytical Chemistry, 77 (2005) 3452-3460.

[43] M. Volny, W.T. Elam, A. Branca, B.D. Ratner, F. Turecek, Preparative soft and reactive landing of multiply charged protein ions on a plasma-treated metal surface, Analytical Chemistry, 77 (2005) 48904896.

[44] H.J. Rader, A. Rouhanipour, A.M. Talarico, V. Palermo, P. Samori, K. Mullen, Processing of giant graphene molecules by soft-landing mass spectrometry, Nature Materials, 5 (2006) 276-280.

[45] R.E. Palmer, S. Pratontep, H.G. Boyen, Nanostructured surfaces from size-selected clusters, Nature Materials, 2 (2003) 443-448.

[46] U. Heiz, F. Vanolli, L. Trento, W.D. Schneider, Chemical reactivity of size-selected supported clusters: An experimental setup, Review of Scientific Instruments, 68 (1997) 1986-1994.

[47] S. Vajda, M.J. Pellin, J.P. Greeley, C.L. Marshall, L.A. Curtiss, G.A. Ballentine, J.W. Elam, S. CatillonMucherie, P.C. Redfern, F. Mehmood, P. Zapol, Subnanometre platinum clusters as highly active and selective catalysts for the oxidative dehydrogenation of propane, Nature Materials, 8 (2009) 213-216. [48] G.E. Johnson, M. Lysonski, J. Laskin, In situ reactivity and TOF-SIMS analysis of surfaces prepared by soft and reactive landing of mass-selected ions, Analytical Chemistry, 82 (2010) 5718-5727.

[49] Z.X. Nie, G.T. Li, M.P. Goodwin, L. Gao, J. Cyriac, R.G. Cooks, In Situ SIMS Analysis and Reactions of Surfaces Prepared by Soft Landing of Mass-Selected Cations and Anions Using an Ion Trap Mass Spectrometer, Journal of the American Society for Mass Spectrometry, 20 (2009) 949-956.

[50] J. Cyriac, M. Wleklinski, G.T. Li, L. Gao, R.G. Cooks, In situ Raman spectroscopy of surfaces modified by ion soft landing, Analyst, 137 (2012) 1363-1369.

[51] M. Volny, A. Sengupta, C.B. Wilson, B.D. Swanson, E.J. Davis, F. Turecek, Surface-enhanced Raman spectroscopy of soft-landed polyatomic ions and molecules, Analytical Chemistry, 79 (2007) 4543-4551. [52] Q.C. Hu, P. Wang, P.L. Gassman, J. Laskin, In situ studies of soft- and reactive landing of massselected ions using infrared reflection absorption spectroscopy, Analytical Chemistry, 81 (2009) 73027308.

[53] S. Nagaoka, T. Matsumoto, K. Ikemoto, M. Mitsui, A. Nakajima, Soft-landing isolation of multidecker V-2(benzene)(3) complexes in an organic monolayer matrix: An infrared spectroscopy and thermal desorption study, Journal of the American Chemical Society, 129 (2007) 1528-+.

[54] J.P. Cowin, A.A. Tsekouras, M.J. Iedema, K. Wu, G.B. Ellison, Immobility of protons in ice from 30 to 190 K, Nature, 398 (1999) 405-407.

[55] Z.T. Deng, N. Thontasen, N. Malinowski, G. Rinke, L. Harnau, S. Rauschenbach, K. Kern, A Close Look at Proteins: Submolecular Resolution of Two- and Three-Dimensionally Folded Cytochrome $\mathrm{c}$ at Surfaces, Nano Letters, 12 (2012) 2452-2458. 
[56] N. Hauptmann, K. Scheil, T.G. Gopakumar, F.L. Otte, C. Schütt, R. Herges, R. Berndt, Surface Control of Alkyl Chain Conformations and 2D Chiral Amplification, Journal of the American Chemical Society, 135 (2013) 8814-8817.

[57] N. Bajales, S. Schmaus, T. Miyamashi, W. Wulfhekel, J. Wilhelm, M. Walz, M. Stendel, A. Bagrets, F. Evers, S. Ulas, B. Kern, A. Bottcher, M.M. Kappes, $C_{58}$ on Au(111): A scanning tunneling microscopy study, Journal of Chemical Physics, 138 (2013) 104703.

[58] S. Ulas, D. Loffler, P. Weis, A. Bottcher, M.M. Kappes, Desorption of $\mathrm{C}_{60}$ upon thermal decomposition of cesium $C_{58}$ fullerides, Journal of Chemical Physics, 136 (2012) 114708.

[59] G.E. Johnson, C. Wang, T. Priest, J. Laskin, Monodisperse $\mathrm{Au}_{11}$ clusters prepared by soft landing of mass selected ions, Analytical Chemistry, 83 (2011) 8069-8072.

[60] J.L.P. Benesch, B.T. Ruotolo, D.A. Simmons, N.P. Barrera, N. Morgner, L. Wang, H.R. Saibil, C.V. Robinson, Separating and visualising protein assemblies by means of preparative mass spectrometry and microscopy, Journal of Structural Biology, 172 (2010) 161-168.

[61] M.E. Bier, J.W. Amy, R.G. Cooks, J.E.P. Syka, P. Ceja, G. Stafford, A tandem quadrupole massspectrometer for the study of surface-induced dissociation, International Journal of Mass Spectrometry and Ion Processes, 77 (1987) 31-47.

[62] V.H. Wysocki, J.M. Ding, J.L. Jones, J.H. Callahan, F.L. King, Surface-induced dissociation in tandem quadrupole mass spectrometers - a comparison of 3 designs, Journal of the American Society for Mass Spectrometry, 3 (1992) 27-32.

[63] Z. Ouyang, V. Grill, J. Alvarez, C.H. Doerge, L. Gianelli, P. Thomas, H.W. Rohrs, R.G. Cooks, A multiquadrupole tandem mass spectrometer for the study of ion/surface collision processes, Review of Scientific Instruments, 73 (2002) 2375-2391.

[64] M.E. Bier, J.C. Schwartz, K.L. Schey, R.G. Cooks, Tandem mass-spectrometry using an in-line ion surface collision device, International Journal of Mass Spectrometry and Ion Processes, 103 (1990) 1-19. [65] A.S. Galhena, S. Dagan, C.M. Jones, R.L. Beardsley, V.N. Wysocki, Surface-induced dissociation of peptides and protein complexes in a quadrupole/Time-of-Flight mass spectrometer, Analytical Chemistry, 80 (2008) 1425-1436.

[66] K.L. Schey, D.A. Durkin, K.R. Thornburg, Design and performance of an in-line surface-induced dissociation device in a 4-sector mass-spectrometer, Journal of the American Society for Mass Spectrometry, 6 (1995) 257-263.

[67] S.A. Lammert, R.G. Cooks, Surface-induced dissociation of molecular-ions in a quadrupole ion trap mass-spectrometer, Journal of the American Society for Mass Spectrometry, 2 (1991) 487-491.

[68] B.E. Winger, H.J. Laue, S.R. Horning, R.K. Julian, S.A. Lammert, D.E. Riederer, R.G. Cooks, Hybrid BEEQ tandem mass-spectrometer for the study of ion surface collision processes, Review of Scientific Instruments, 63 (1992) 5613-5625.

[69] K. Schey, R.G. Cooks, R. Grix, H. Wollnik, A tandem time-of-flight mass-spectrometer for surfaceinduced dissociation, International Journal of Mass Spectrometry and Ion Processes, 77 (1987) 49-61. [70] L.L. Haney, D.E. Riederer, Delayed extraction for improved resolution of ion/surface collision products by time-of-flight mass spectrometry, Analytica Chimica Acta, 397 (1999) 225-233.

[71] E. Stone, K.J. Gillig, B. Ruotolo, K. Fuhrer, M. Gonin, A. Schultz, D.H. Russell, Surface-induced dissociation on a MALDI-ion mobility-orthogonal time-of-flight mass spectrometer: Sequencing peptides from an "in-solution" protein digest, Analytical Chemistry, 73 (2001) 2233-2238.

[72] C.M. Gamage, F.M. Fernandez, K. Kuppannan, V.H. Wysocki, Submicrosecond surface-induced dissociation of peptide ions in a MALDI TOF MS, Analytical Chemistry, 76 (2004) 5080-5091.

[73] E.N. Nikolaev, A. Somogyi, D.L. Smith, C.G. Gu, V.H. Wysocki, C.D. Martin, G.L. Samuelson, Implementation of low-energy surface-induced dissociation (eV SID) and high-energy collision-induced dissociation ( $\mathrm{keV}$ CID) in a linear sector-TOF hybrid tandem mass spectrometer, International Journal of Mass Spectrometry, 212 (2001) 535-551. 
[74] C.F. Ijames, C.L. Wilkins, Surface-induced dissociation by fourier-transform mass-spectrometry, Analytical Chemistry, 62 (1990) 1295-1299.

[75] J. Laskin, E.V. Denisov, A.K. Shukla, S.E. Barlow, J.H. Futrell, Surface-induced dissociation in a Fourier transform ion cyclotron resonance mass spectrometer: Instrument design and evaluation, Analytical Chemistry, 74 (2002) 3255-3261.

[76] R.A. Chorush, D.P. Little, S.C. Beu, T.D. Wood, F.W. McLafferty, Surface-induced dissociation of multiply protonated proteins, Analytical Chemistry, 67 (1995) 1042-1046.

[77] W.Q. Zhong, E.N. Nikolaev, J.H. Futrell, V.H. Wysocki, Tandem Fourier transform mass spectrometry studies of surface-induced dissociation of benzene monomer and dimer ions on a self-assembled fluorinated alkanethiolate monolayer surface, Analytical Chemistry, 69 (1997) 2496-2503.

[78] V.S. Rakov, J.H. Futrell, E.V. Denisov, E.N. Nikolaev, Instrumentation of kinetic energy-resolved surface-induced dissociation in Fourier transform mass spectrometry, European Journal of Mass Spectrometry, 6 (2000) 299-317.

[79] W.J. Sun, J.C. May, D.H. Russell, A novel surface-induced dissociation instrument for ion mobilitytime-of-flight mass spectrometry, International Journal of Mass Spectrometry, 259 (2007) 79-86.

[80] W.J. Sun, J.C. May, K.J. Gillig, D.H. Russell, A dual time-of-flight apparatus for an ion mobilitysurface-induced dissociation-mass spectrometer for high-throughput peptide sequencing, International Journal of Mass Spectrometry, 287 (2009) 39-45.

[81] M.W. Zhou, C.S. Huang, V.H. Wysocki, Surface-Induced Dissociation of Ion Mobility-Separated Noncovalent Complexes in a Quadrupole/Time-of-Flight Mass Spectrometer, Analytical Chemistry, 84 (2012) 6016-6023.

[82] A. Budrevich, B. Tsipinyuk, A. Bekkerman, E. Kolodney, Surface scattering of hyperthermal (10-50 eV) neutral $C_{60}$ : Angular and energy distributions, Journal of Chemical Physics, 106 (1997) 5771-5774.

[83] J. Kubista, Z. Dolejsek, Z. Herman, Energy partitioning in collisions of slow polyatomic ions with surfaces: ethanol molecular ions on stainless steel surfaces, European Mass Spectrometry, 4 (1998) 311319.

[84] R. Worgotter, J. Kubista, J. Zabka, Z. Dolejsek, T.D. Mark, Z. Herman, Surface-induced reactions and decomposition of the benzene molecular ion $\mathrm{C} 6 \mathrm{H6} 6$ : Product ion intensities, angular and translational energy distributions, International Journal of Mass Spectrometry, 174 (1998) 53-62.

[85] H.L. de Clercq, A.D. Sen, A.K. Shukla, J.H. Futrell, Inelastic ion-surface collisions: scattering and dissociation of low energy benzene molecular cations, International Journal of Mass Spectrometry, 212 (2001) 491-504.

[86] A.K. Shukla, J.H. Futrell, A beam scattering instrument for the dynamics studies of surface-induced dissociation processes, Review of Scientific Instruments, 74 (2003) 168-175.

[87] B.E. Winger, R.K. Julian, R.G. Cooks, C.E.D. Chidsey, Surface-reactions and surface-induced dissociation of polyatomic ions at self-assembled organic monolayer surfaces, Journal of the American Chemical Society, 113 (1991) 8967-8969.

[88] V.H. Wysocki, J.L. Jones, J.M. Ding, Polyatomic ion/surface collisions at self-assembled monolayers films, Journal of the American Chemical Society, 113 (1991) 8969-8970.

[89] J. Laskin, J.H. Futrell, Energy transfer in collisions of peptide ions with surfaces, Journal of Chemical Physics, 119 (2003) 3413-3420.

[90] U. Heiz, E.L. Bullock, Fundamental aspects of catalysis on supported metal clusters, Journal of Materials Chemistry, 14 (2004) 564-577.

[91] D.-C. Lim, C.-C. Hwang, G. Gantefor, Y.D. Kim, Model catalysts of supported Au nanoparticles and mass-selected clusters, Physical Chemistry Chemical Physics, 12 (2010) 15172-15180.

[92] Z. Herman, Collisions of slow polyatomic ions with surfaces: The scattering method and results, Journal of the American Society for Mass Spectrometry, 14 (2003) 1360-1372. 
[93] K.Y. Song, O. Meroueh, W.L. Hase, Dynamics of $\mathrm{Cr}(\mathrm{CO})_{6}{ }^{+}$collisions with hydrogenated surfaces, Journal of Chemical Physics, 118 (2003) 2893-2902.

[94] J. Kubišta, Z. Dolejšek, Z. Herman, Energy partitioning in collisions of slow polyatomic ions with surfaces: ethanol molecular ions on stainless steel surfaces, European Journal of Mass Spectrometry, 4 (1998) 311-319.

[95] R. Wörgötter, J. Kubišta, J. Žabka, Z. Dolejšek, T.D. Märk, Z. Herman, Surface-induced reactions and decomposition of the benzene molecular ion $\mathrm{C}_{6} \mathrm{H}_{6}{ }^{+}$: Product ion intensities, angular and translational energy distributions, International Journal of Mass Spectrometry and Ion Processes, 174 (1998) 53-62.

[96] J. Roithova, J. Zabka, Z. Dolejsek, Z. Herman, Collisions of slow polyatomic ions with surfaces:

Dissociation and chemical reactions of $\mathrm{CD}_{5}{ }^{+}, \mathrm{CD}_{4}{ }^{+}, \mathrm{CD}_{3}{ }^{+}$, and their isotopic variants on room-temperature and heated carbon surfaces, Journal of Physical Chemistry B, 106 (2002) 8293-8301.

[97] A.K. Shukla, J.H. Futrell, Dynamics of hyperthermal energy ion-surface collisions: dissociative and non-dissociative scattering of ethanol cations from a self-assembled monolayer surface of fluorinated alkyl thiol on Au(111), International Journal of Mass Spectrometry, 223 (2003) 783-801.

[98] A.K. Shukla, J.H. Futrell, A.D. Sen, Dynamics of the dissociative and nondissociative scattering of hyperthermal $\mathrm{CS}_{2}{ }^{+}$from a self-assembled fluoroalkyl monolayer surface on gold substrate, Journal of Chemical Physics, 118 (2003) 11217-11225.

[99] J.W. Shen, Y.H. Yim, B.B. Feng, V. Grill, C. Evans, R.G. Cooks, Soft landing of ions onto self-assembled hydrocarbon and fluorocarbon monolayer surfaces, International Journal of Mass Spectrometry, 183 (1999) 423-435.

[100] D.L. Smith, V.H. Wysocki, R. Colorado, O.E. Shmakova, M. Graupe, T.R. Lee, Low-energy ion-surface collisions characterize alkyland fluoroalkyl-terminated self-assembled monolayers on gold, Langmuir, 18 (2002) 3895-3902.

[101] J. Zabka, Z. Dolejsek, Z. Herman, Energy partitioning in collisions of slow polyatomic ions with surfaces: Ethanol molecular ions on surfaces covered by self-assembled monolayers (CF-SAM, CH-SAM, COOH-SAM), Journal of Physical Chemistry A, 106 (2002) 10861-10869.

[102] J. Laskin, E. Denisov, J. Futrell, A comparative study of collision-induced and surface-induced dissociation. 1. Fragmentation of protonated dialanine, Journal of the American Chemical Society, 122 (2000) 9703-9714.

[103] O. Meroueh, W.L. Hase, Dynamics of energy transfer in peptide-surface collisions, Journal of the American Chemical Society, 124 (2002) 1524-1531.

[104] S.B.M. Bosio, W.L. Hase, Simulations of energy transfer in $\mathrm{Cr}(\mathrm{CO})_{6}{ }^{+}$surface-induced dissociation, International Journal of Mass Spectrometry, 174 (1998) 1-9.

[105] O. Meroueh, W.L. Hase, Energy transfer pathways in the collisional activation of peptides, International Journal of Mass Spectrometry, 201 (2000) 233-244.

[106] J.P. Wang, S.O. Meroueh, Y.F. Wang, W.L. Hase, Efficiency of energy transfer in protonated diglycine and dialanine SID - Effects of collision angle, peptide ion size, and intramolecular potential, International Journal of Mass Spectrometry, 230 (2003) 57-64.

[107] A. Rahaman, W.L. Hase, K. Song, J. Wang, O. Meroueh, Chemical Dynamics Simulations of Energy Transfer and Unimolecular Decomposition in Collision-Induced Dissociation (CID) and Surface-Induced Dissociation (SID), in: J. Laskin, C. Lifshitz (Eds.) Principles of Mass Spectrometry Applied to Biomolecules, John Wiley \& Sons., Inc., Hoboken, NJ, 2006.

[108] G.L. Barnes, W.L. Hase, Energy Transfer, Unfolding, and Fragmentation Dynamics in Collisions of NProtonated Octaglycine with an H-SAM Surface, Journal of the American Chemical Society, 131 (2009) 17185-17193.

[109] L. Yang, O.A. Mazyar, U. Lourderaj, J.P. Wang, M.T. Rodgers, E. Martinez-Nunez, S.V. Addepalli, W.L. Hase, Chemical dynamics simulations of energy transfer in collisions of protonated peptide-ions 
with a perfluorinated alkylthiol self-assembled monolayer surface, Journal of Physical Chemistry C, 112 (2008) 9377-9386.

[110] J. Laskin, T.H. Bailey, E.V. Denisov, J.H. Futrell, On the relative stability of singly protonated desArg $^{1-}$ and des-Arg'-bradykinins, Journal of Physical Chemistry A, 106 (2002) 9832-9836.

[111] J. Laskin, J.H. Futrell, On the efficiency of energy transfer in collisional activation of small peptides, Journal of Chemical Physics, 116 (2002) 4302-4310.

[112] K. Vekey, A. Somogyi, V.H. Wysocki, Internal energy-distribution of benzene molecular-ions in surface-induced dissociation, Journal of Mass Spectrometry, 30 (1995) 212-217.

[113] S.O. Meroueh, Y.F. Wang, W.L. Hase, Direct dynamics Simulations of collision- and surface-induced dissociation of N-protonated glycine. Shattering fragmentation, Journal of Physical Chemistry A, 106 (2002) 9983-9992.

[114] K. Park, B. Deb, K. Song, W.L. Hase, Importance of Shattering Fragmentation in the SurfaceInduced Dissociation of Protonated Octaglycine, Journal of the American Society for Mass Spectrometry, 20 (2009) 939-948.

[115] J. Laskin, J.H. Futrell, Surface-induced dissociation of peptide ions: Kinetics and dynamics, Journal of the American Society for Mass Spectrometry, 14 (2003) 1340-1347.

[116] J. Laskin, K.M. Beck, J.J. Hache, J.H. Futrell, Surface-induced dissociation of ions produced by matrix-assisted laser desorption/ionization in a Fourier transform ion cyclotron resonance mass spectrometer, Analytical Chemistry, 76 (2004) 351-356.

[117] F.M. Fernandez, V.H. Wysocki, J.H. Futrell, J. Laskin, Protein identification via surface-induced dissociation in an FT-ICR mass spectrometer and a patchwork sequencing approach, Journal of the American Society for Mass Spectrometry, 17 (2006) 700-709.

[118] J.L. Jones, A.R. Dongre, A. Somogyi, V.H. Wysocki, Sequence dependence of peptide fragmentation efficiency curves determined by electrospray-ionization surface-induced dissociation massspectrometry, Journal of the American Chemical Society, 116 (1994) 8368-8369.

[119] G. Tsaprailis, H. Nair, A. Somogyi, V.H. Wysocki, W.Q. Zhong, J.H. Futrell, S.G. Summerfield, S.J. Gaskell, Influence of secondary structure on the fragmentation of protonated peptides, Journal of the American Chemical Society, 121 (1999) 5142-5154.

[120] H. Nair, V.H. Wysocki, Are peptides without basic residues protonated primarily at the amino terminus?, International Journal of Mass Spectrometry, 174 (1998) 95-100.

[121] V.H. Wysocki, G. Tsaprailis, L.L. Smith, L.A. Breci, Special feature: Commentary - Mobile and localized protons: a framework for understanding peptide dissociation, Journal of Mass Spectrometry, 35 (2000) 1399-1406.

[122] C.G. Gu, G. Tsaprailis, L. Breci, V.H. Wysocki, Selective gas-phase cleavage at the peptide bond terminal to aspartic acid in fixed-charge derivatives of asp-containing peptides, Analytical Chemistry, 72 (2000) 5804-5813.

[123] G. Tsaprailis, A. Somogyi, E.N. Nikolaev, V.H. Wysocki, Refining the model for selective cleavage at acidic residues in arginine-containing protonated peptides, International Journal of Mass Spectrometry, 195 (2000) 467-479.

[124] Y.Y. Huang, V.H. Wysocki, D.L. Tabb, J.R. Yates, The influence of histidine on cleavage C-terminal to acidic residues in doubly protonated tryptic peptides, International Journal of Mass Spectrometry, 219 (2002) 233-244.

[125] J. Laskin, T.H. Bailey, J.H. Futrell, Mechanisms of peptide fragmentation from time- and energyresolved surface-induced dissociation studies: Dissociation of angiotensin analogs, International Journal of Mass Spectrometry, 249 (2006) 462-472.

[126] J.M. Spraggins, J.A. Lloyd, M.V. Johnston, J. Laskin, D.P. Ridge, Fragmentation mechanisms of oxidized peptides elucidated by SID, RRKM modeling, and molecular dynamics, Journal of the American Society for Mass Spectrometry, 20 (2009) 1579-1592. 
[127] J. Laskin, Z.B. Yang, T. Song, C. Lam, I.K. Chu, Effect of the basic residue on the energetics, dynamics, and mechanisms of gas-phase fragmentation of protonated peptides, Journal of the American Chemical Society, 132 (2010) 16006-16016.

[128] T.H. Bailey, J. Laskin, J.H. Futrell, Energetics of selective cleavage at acidic residues studied by timeand energy-resolved surface-induced dissociation in FT-ICR MS, International Journal of Mass Spectrometry, 222 (2003) 313-327.

[129] J. Laskin, T.H. Bailey, J.H. Futrell, Fragmentation energetics for angiotensin II and its analogs from time-and energy-resolved surface-induced dissociation studies, International Journal of Mass Spectrometry, 234 (2004) 89-99.

[130] J. Laskin, Energy and entropy effects in the gas phase dissociation of peptides and proteins, in: J. Laskin, C. Lifshitz (Eds.) Principles of Mass Spectrometry Applied to Biomolecules, John Wiley \& Sons., Inc., Hoboken, NJ, 2006.

[131] J. Laskin, Energetics and dynamics of fragmentation of protonated leucine enkephalin from timeand energy-resolved surface-induced dissociation studies, Journal of Physical Chemistry A, 110 (2006) 8554-8562.

[132] J. Laskin, M. Byrd, J. Futrell, Internal energy distributions resulting from sustained off-resonance excitation in $\mathrm{ftms}$. I. Fragmentation of the bromobenzene radical cation, International Journal of Mass Spectrometry, 195 (2000) 285-302.

[133] J. Laskin, J. Futrell, Internal energy distributions resulting from sustained off-resonance excitation in fourier transform ion cyclotron resonance mass spectrometry. li. Fragmentation of the 1bromonaphthalene radical cation, Journal of Physical Chemistry A, 104 (2000) 5484-5494.

[134] H. Lioe, J. Laskin, G.E. Reid, R.A.J. O'Hair, Energetics and dynamics of the fragmentation reactions of protonated peptides containing methionine sulfoxide or aspartic acid via energy- and time-resolved surface induced dissociation, Journal of Physical Chemistry A, 111 (2007) 10580-10588.

[135] I.K. Chu, J. Laskin, Review formation of peptide radical ions through dissociative electron transfer in ternary metal-ligand-peptide complexes, European Journal of Mass Spectrometry, 17 (2011) 543-556. [136] J. Laskin, Z. Yang, I.K. Chu, Energetics and dynamics of electron transfer and proton transfer in dissociation of metal'"(salen)-peptide complexes in the gas phase, Journal of the American Chemical Society, 130 (2008) 3218-3230.

[137] J. Laskin, J.H. Futrell, I.K. Chu, Is dissociation of peptide radical cations an ergodic process?, Journal of the American Chemical Society, 129 (2007) 9598-+.

[138] Z.B. Yang, C. Lam, I.K. Chu, J. Laskin, The effect of the secondary structure on dissociation of peptide radical cations: Fragmentation of angiotensin III and its analogues, Journal of Physical Chemistry B, 112 (2008) 12468-12478.

[139] J. Laskin, Z.B. Yang, C. Lam, I.K. Chu, Energy and entropy effects in dissociation of peptide radical anions, International Journal of Mass Spectrometry, 316 (2012) 251-258.

[140] J.C. Jurchen, E.R. Williams, Origin of asymmetric charge partitioning in the dissociation of gasphase protein homodimers, Journal of the American Chemical Society, 125 (2003) 2817-2826.

[141] C.M. Jones, R.L. Beardsley, A.S. Galhena, S. Dagan, G.L. Cheng, V.H. Wysocki, Symmetrical gasphase dissociation of noncovalent protein complexes via surface collisions, Journal of the American Chemical Society, 128 (2006) 15044-15045.

[142] A.E. Blackwell, E.D. Dodds, V. Bandarian, V.H. Wysocki, Revealing the Quaternary Structure of a Heterogeneous Noncovalent Protein Complex through Surface-Induced Dissociation, Analytical Chemistry, 83 (2011) 2862-2865.

[143] E.D. Dodds, A.E. Blackwell, C.M. Jones, K.L. Holso, D.J. O'Brien, M.H.J. Cordes, V.H. Wysocki, Determinants of Gas-Phase Disassembly Behavior in Homodimeric Protein Complexes with Related Yet Divergent Structures, Analytical Chemistry, 83 (2011) 3881-3889. 
[144] M.W. Zhou, S. Dagan, V.H. Wysocki, Protein Subunits Released by Surface Collisions of Noncovalent Complexes: Nativelike Compact Structures Revealed by Ion Mobility Mass Spectrometry, Angewandte Chemie-International Edition, 51 (2012) 4336-4339.

[145] M.W. Zhou, S. Dagan, V.H. Wysocki, Impact of charge state on gas-phase behaviors of noncovalent protein complexes in collision induced dissociation and surface induced dissociation, Analyst, 138 (2013) 1353-1362.

[146] M.W. Zhou, C.M. Jones, V.H. Wysocki, Dissecting the Large Noncovalent Protein Complex GroEL with Surface-Induced Dissociation and Ion Mobility Mass Spectrometry, Analytical Chemistry, 85 (2013) 8262-8267.

[147] A.K. Badu-Tawiah, J. Cyriac, R.G. Cooks, Reactions of Organic lons at Ambient Surfaces in a SolventFree Environment, Journal of the American Society for Mass Spectrometry, 23 (2012) 842-849.

[148] A.K. Badu-Tawiah, C.P. Wu, R.G. Cooks, Ambient lon Soft Landing, Analytical Chemistry, 83 (2011) 2648-2654.

[149] J.W. Shen, C. Evans, N. Wade, R.G. Cooks, lon-ion collisions leading to formation of C-C bonds at surfaces: An interfacial Kolbe reaction, Journal of the American Chemical Society, 121 (1999) 9762-9763. [150] J. Alvarez, J.H. Futrell, J. Laskin, Soft-landing of peptides onto self-assembled monolayer surfaces, Journal of Physical Chemistry A, 110 (2006) 1678-1687.

[151] M.B.J. Wijesundara, Y. Ji, B. Ni, S.B. Sinnott, L. Hanley, Effect of polyatomic ion structure on thinfilm growth: Experiments and molecular dynamics simulations, Journal of Applied Physics, 88 (2000) 5004-5016.

[152] N. Wade, C. Evans, S.C. Jo, R.G. Cooks, Silylation of an OH-terminated self-assembled monolayer surface through low-energy collisions of ions: a novel route to synthesis and patterning of surfaces, Journal of Mass Spectrometry, 37 (2002) 591-602.

[153] N. Wade, B. Gologan, A. Vincze, R.G. Cooks, D.M. Sullivan, M.L. Bruening, Esterification and ether formation at a hydroxyl-terminated self-assembled monolayer surface using low-energy collisions of polyatomic cations, Langmuir, 18 (2002) 4799-4808.

[154] P. Wang, O. Hadjar, J. Laskin, Covalent immobilization of peptides on self-assembled monolayer surfaces using soft-landing of mass-selected ions, Journal of the American Chemical Society, 129 (2007) 8682-8683.

[155] P. Wang, O. Hadjar, P.L. Gassman, J. Laskin, Reactive landing of peptide ions on self-assembled monolayer surfaces: an alternative approach for covalent immobilization of peptides on surfaces, Physical Chemistry Chemical Physics, 10 (2008) 1512-1522.

[156] Q.C. Hu, J. Laskin, Reactive landing of dendrimer ions onto activated self-assembled monolayer surfaces, Journal of Physical Chemistry C, (2014).

[157] S. Nagaoka, K. Ikemoto, K. Horiuchi, A. Nakajima, Soft- and Reactive-Landing of Cr(aniline) ${ }_{2}$ Sandwich Complexes onto Self-Assembled Monolayers: Separation between Functional and Binding Sites, Journal of the American Chemical Society, 133 (2011) 18719-18727.

[158] M. Volny, W.T. Elam, B.D. Ratner, F. Turecek, Preparative soft and reactive landing of gas-phase ions on plasma-treated metal surfaces, Analytical Chemistry, 77 (2005) 4846-4853.

[159] G.E. Johnson, J. Laskin, Preparation of Surface Organometallic Catalysts by Gas-Phase Ligand Stripping and Reactive Landing of Mass-Selected lons, Chemistry - A European Journal, 16 (2010) 1443314438.

[160] M. Mitsui, S. Nagaoka, T. Matsumoto, A. Nakajima, Soft-landing isolation of vanadium-benzene sandwich clusters on a room-temperature substrate using $\mathrm{n}$-alkanethiolate self-assembled monolayer matrixes, Journal of Physical Chemistry B, 110 (2006) 2968-2971.

[161] S. Nagaoka, K. Ikemoto, K. Horiuchi, A. Nakajima, Soft- and Reactive-Landing of Cr(aniline)(2) Sandwich Complexes onto Self-Assembled Monolayers: Separation between Functional and Binding Sites, Journal of the American Chemical Society, 133 (2011) 18719-18727. 
[162] J. Laskin, P. Wang, O. Hadjar, Soft-landing of Co"'(salen) ${ }^{+}$and MnIII(salen) ${ }^{+}$on self-assembled monolayer surfaces, Journal of Physical Chemistry C, 114 (2010) 5305-5311.

[163] N. Thontasen, G. Levita, N. Malinowski, Z. Deng, S. Rauschenbach, K. Kern, Grafting Crown Ether Alkali Host-Guest Complexes at Surfaces by Electrospray Ion Beam Deposition, Journal of Physical Chemistry C, 114 (2010) 17768-17772.

[164] L. Hanley, H.J. Lim, D.G. Schultz, S.B. Wainhaus, P. deSainteClaire, W.L. Hase, Surface energy transfer by low energy polyatomic ion collisions, Nuclear Instruments \& Methods in Physics Research Section B-Beam Interactions with Materials and Atoms, 125 (1997) 218-222.

[165] S.C. Nanita, Z. Takats, R.G. Cooks, S. Myung, D.E. Clemmer, Chiral enrichment of serine via formation, dissociation, and soft-landing of octameric cluster ions, Journal of the American Society for Mass Spectrometry, 15 (2004) 1360-1365.

[166] B. Wang, B. Yoon, M. Konig, Y. Fukamori, F. Esch, U. Heiz, U. Landman, Size-Selected Monodisperse Nanoclusters on Supported Graphene: Bonding, Isomerism, and Mobility, Nano Letters, 12 (2012) 59075912.

[167] B. Yoon, H. Hakkinen, U. Landman, A.S. Worz, J.M. Antonietti, S. Abbet, K. Judai, U. Heiz, Charging effects on bonding and catalyzed oxidation of $\mathrm{CO}$ on $\mathrm{Au}_{8}$ clusters on MgO, Science, 307 (2005) 403-407. [168] G. Kwon, G.A. Ferguson, C.J. Heard, E.C. Tyo, C.R. Yin, J. DeBartolo, S. Seifert, R.E. Winans, A.J. Kropf, J. Greeley, R.L. Johnston, L.A. Curtiss, M.J. Pellin, S. Vajda, Size-Dependent Subnanometer Pd Cluster $\left(\mathrm{Pd}_{4}, \mathrm{Pd}_{6}\right.$, and $\left.\mathrm{Pd}_{17}\right)$ Water Oxidation Electrocatalysis, Acs Nano, 7 (2013) 5808-5817.

[169] Y. Lei, F. Mehmood, S. Lee, J. Greeley, B. Lee, S. Seifert, R.E. Winans, J.W. Elam, R.J. Meyer, P.C. Redfern, D. Teschner, R. Schlogl, M.J. Pellin, L.A. Curtiss, S. Vajda, Increased Silver Activity for Direct Propylene Epoxidation via Subnanometer Size Effects, Science, 328 (2010) 224-228.

[170] B. Gologan, Z. Takats, J. Alvarez, J.M. Wiseman, N. Talaty, Z. Ouyang, R.G. Cooks, lon soft-landing into liquids: Protein identification, separation, and purification with retention of biological activity, Journal of the American Society for Mass Spectrometry, 15 (2004) 1874-1884.

[171] P. Wang, J. Laskin, Helical peptide arrays on self-assembled monolayer surfaces through soft and reactive landing of mass-selected ions, Angewandte Chemie-International Edition, 47 (2008) 6678-6680. [172] B.B. Feng, D.S. Wunschel, C.D. Masselon, L. Pasa-Tolic, R.D. Smith, Retrieval of DNA using softlanding after mass analysis by ESI-FTICR for enzymatic manipulation, Journal of the American Chemical Society, 121 (1999) 8961-8962.

[173] G. Siuzdak, B. Bothner, M. Yeager, C. Brugidou, C.M. Fauquet, K. Hoey, C.M. Chang, Mass spectrometry and viral analysis, Chemistry \& Biology, 3 (1996) 45-48.

[174] D. Loffler, S.S. Jester, P. Weis, A. Bottcher, M.M. Kappes, $C_{n}$ films ( $n=50,52,54,56$, and 58) on graphite: Cage size dependent electronic properties, Journal of Chemical Physics, 124 (2006) 054705. [175] D. Loffler, S. Ulas, S.S. Jester, P. Weis, A. Bottcher, M.M. Kappes, Properties of non-IPR fullerene films versus size of the building blocks, Physical Chemistry Chemical Physics, 12 (2010) 10671-10684. [176] S. Ulas, D. Strelnikov, P. Weis, A. Bottcher, M.M. Kappes, Incorporating $C_{2}$ into $C_{60}$ films, Journal of Chemical Physics, 136 (2012) 014701.

[177] G.R. Blacken, M. Volny, T. Vaisar, M. Sadılek, F. Turecek, In Situ Enrichment of Phosphopeptides on MALDI Plates Functionalized by Reactive Landing of Zirconium(IV)-n-Propoxide Ions, Analytical Chemistry, 79 (2007) 5449-5456.

[178] W. Hoffmann, G. Verbeck, Toward a Reusable Surface-Enhanced Raman Spectroscopy (SERS) Substrate by Soft-Landing Ion Mobility, Appl. Spectrosc., 67 (2013) 656-660.

[179] A.A. Tsekouras, M.J. ledema, J.P. Cowin, Soft-landed ion diffusion studies on vapor-deposited hydrocarbon films, Journal of Chemical Physics, 111 (1999) 2222-2234.

[180] W.P. Peng, G.E. Johnson, I.C. Fortmeyer, P. Wang, O. Hadjar, R.G. Cooks, J. Laskin, Redox chemistry in thin layers of organometallic complexes prepared using ion soft landing, Physical Chemistry Chemical Physics, 13 (2011) 267-275. 
[181] N. Hauptmann, C. Hamann, H. Tang, R. Berndt, Switching and charging of a ruthenium dye on $\mathrm{Ag}(111)$, Physical Chemistry Chemical Physics, 15 (2013) 10326-10330.

[182] Q.C. Hu, P. Wang, J. Laskin, Effect of the surface on the secondary structure of soft landed peptide ions, Physical Chemistry Chemical Physics, 12 (2010) 12802-12810.

[183] S. Kahle, Z.T. Deng, N. Malinowski, C. Tonnoir, A. Forment-Aliaga, N. Thontasen, G. Rinke, D. Le, V. Turkowski, T.S. Rahman, S. Rauschenbach, M. Ternes, K. Kern, The Quantum Magnetism of Individual Manganese-12-Acetate Molecular Magnets Anchored at Surfaces, Nano Letters, 12 (2012) 518-521. [184] O. Hadjar, J.H. Futrell, J. Laskin, First observation of charge reduction and desorption kinetics of multiply protonated peptides soft landed onto self-assembled monolayer surfaces, Journal of Physical Chemistry C, 111 (2007) 18220-18225.

[185] G.L. Barnes, K. Young, L. Yang, W.L. Hase, Fragmentation and reactivity in collisions of protonated diglycine with chemically modified perfluorinated alkylthiolate-self-assembled monolayer surfaces, Journal of Chemical Physics, 134 (2011) 094106.

[186] J. Laskin, P. Wang, O. Hadjar, J.H. Futrell, J. Alvarez, Z.G. Cooks, Charge retention by peptide ions soft-landed onto self-assembled monolayer surfaces, International Journal of Mass Spectrometry, 265 (2007) 237-243.

[187] G.E. Johnson, T. Priest, J. Laskin, Charge retention by gold clusters on surfaces prepared using soft landing of mass selected ions, ACS Nano, 6 (2012) 573-582.

[188] G.E. Johnson, T. Priest, J. Laskin, Coverage-dependent charge reduction of cationic gold clusters on surfaces prepared using soft landing of mass-selected ions, Journal of Physical Chemistry C, 116 (2012) 24977-24986.

[1] J.J. Thomson, Rays of positive electricity and their application to chemical analyses, Longmans, Green and Co., London, New York, 1913.

[2] V. Franchetti, B.H. Solka, W.E. Baitinger, J.W. Amy, R.G. Cooks, Soft Landing of lons as a Means of Surface Modification, International Journal of Mass Spectrometry and Ion Processes, 23 (1977) 29-35.

[3] M.D.A. Mabud, M.J. Dekrey, R.G. Cooks, Surface-induced dissociation of molecular ions, International Journal of Mass Spectrometry and Ion Processes, 67 (1985) 285-294.

[4] A.R. Dongre, A. Somogyi, V.H. Wysocki, Surface-induced dissociation: An effective tool to probe structure, energetics and fragmentation mechanisms of protonated peptides, Journal of Mass Spectrometry, 31 (1996) 339-350.

[5] A.R. Dongre, J.L. Jones, A. Somogyi, V.H. Wysocki, Influence of peptide composition, gas-phase basicity, and chemical modification on fragmentation efficiency: Evidence for the mobile proton model, Journal of the American Chemical Society, 118 (1996) 8365-8374.

[6] V. Grill, J. Shen, C. Evans, R.G. Cooks, Collisions of ions with surfaces at chemically relevant energies: Instrumentation and phenomena, Review of Scientific Instruments, 72 (2001) 3149-3179.

[7] B. Gologan, J.M. Wiseman, R.G. Cooks, lon Soft Landing: Instrumentation, Phenomena, and Applications, in: J. Laskin, C. Lifshitz (Eds.) Principles of Mass Spectrometry Applied to Biomolecules, John Wiley \& Sons., Inc., Hoboken, NJ, 2006.

[8] J. Cyriac, T. Pradeep, H. Kang, R. Souda, R.G. Cooks, Low-Energy lonic Collisions at Molecular Solids, Chemical Reviews, 112 (2012) 5356-5411.

[9] J. Laskin, P. Wang, O. Hadjar, Soft-landing of peptide ions onto self-assembled monolayer surfaces: an overview, Physical Chemistry Chemical Physics, 10 (2008) 1079-1090.

[10] G.E. Johnson, Q.C. Hu, J. Laskin, Soft Landing of Complex Molecules on Surfaces, Annual Review of Analytical Chemistry, 4 (2011) 83-104.

[11] G. Verbeck, W. Hoffmann, B. Walton, Soft-landing preparative mass spectrometry, Analyst, 137 (2012) 4393-4407. 
[12] V.H. Wysocki, K.E. Joyce, C.M. Jones, R.L. Beardsley, Surface-induced dissociation of small molecules, peptides, and non-covalent protein complexes, Journal of the American Society for Mass Spectrometry, 19 (2008) 190-208.

[13] R.G. Cooks, T. Ast, A. Mabud, Collisions of polyatomic ions with surfaces, International Journal of Mass Spectrometry, 100 (1990) 209-265.

[14] R.G. Cooks, T. Ast, T. Pradeep, V. Wysocki, Reactions of ions with organic surfaces, Accounts of Chemical Research, 27 (1994) 316-323.

[15] P. Wang, J. Laskin, Surface Modification Using Reactive Landing of Mass-Selected lons, in: R. Hellborg, H.J. Whitlow, Y. Zhang (Eds.) Ion Beams in Nanoscience and Technology, Springer, London, New York, 2009.

[16] T. Raz, R.D. Levine, On the shattering of clusters by surface impact heating, Journal of Chemical Physics, 105 (1996) 8097-8102.

[17] W. Christen, U. Even, T. Raz, R.D. Levine, Collisional energy loss in cluster surface impact: Experimental, model, and simulation studies of some relevant factors, Journal of Chemical Physics, 108 (1998) 10262-10273.

[18] W. Christen, U. Even, Cluster impact chemistry, Journal of Physical Chemistry A, 102 (1998) 94209426.

[19] R.D. Beck, C. Warth, K. May, M.M. Kappes, Surface impact induced shattering of $C_{60}$. Detection of small $C_{m}$ fragments by negative surface ionization, Chemical Physics Letters, 257 (1996) 557-562.

[20] O. Meroueh, W.L. Hase, Effect of surface stiffness on the efficiency of surface-induced dissociation, Physical Chemistry Chemical Physics, 3 (2001) 2306-2314.

[21] J. Laskin, T.H. Bailey, J.H. Futrell, Shattering of peptide ions on self-assembled monolayer surfaces, Journal of the American Chemical Society, 125 (2003) 1625-1632.

[22] T. Ast, D.E. Riederer, S.A. Miller, M. Morris, R.G. Cooks, Collisions of fluorocarbon ions at solidsurfaces - electronic excitation, surface-induced dissociation and chemical sputtering, Organic Mass Spectrometry, 28 (1993) 1021-1033.

[23] C. Xirouchaki, R.E. Palmer, Pinning and implantation of size-selected metal clusters: a topical review, Vacuum, 66 (2002) 167-173.

[24] N. Winograd, B.J. Garrison, Biological Cluster Mass Spectrometry, Annual Review of Physical Chemistry, 61 (2010) 305-322.

[25] R.J. Day, S.E. Unger, R.G. Cooks, Molecular secondary ion mass-spectrometry, Analytical Chemistry, 52 (1980) A557-\&.

[26] A. Benninghoven, Chemical-analysis of inorganic and organic-surfaces and thin-films by static timeof-flight secondary-ion mass-spectrometry (TOF-SIMS), Angew. Chem.-Int. Edit. Engl., 33 (1994) 10231043.

[27] L. Hanley, S.B. Sinnott, The growth and modification of materials via ion-surface processing, Surface Science, 500 (2002) 500-522.

[28] D.C. Jacobs, Reactive collisions of hyperthermal energy molecular ions with solid surfaces, Annual Review of Physical Chemistry, 53 (2002) 379-407.

[29] B. Gologan, J.R. Green, J. Alvarez, J. Laskin, R.G. Cooks, lon/surface reactions and ion soft-landing, Physical Chemistry Chemical Physics, 7 (2005) 1490-1500.

[30] R.W. Gurney, The scattering of positive ions from a platinum surface, Phys. Rev., 32 (1928) 0467-

0477.

[31] C.C. Van Voorhis, K.T. Compton, Accommodation coefficients of positive ions of argon, neon and helium, Phys. Rev., 37 (1931) 1596-1610.

[32] K.S. Woodcock, The emission of negative ions under the bombardment of positive ions, Phys. Rev., 38 (1931) 1696-1703. 
[33] R.E. Honig, The development of secondary ion mass-spectrometry (SIMS) - A retrospective, International Journal of Mass Spectrometry and lon Processes, 66 (1985) 31-54.

[34] J.H. Beynon, A.E. Fontaine, G.R. Lester, An anomalous metastable peak in mass spectrum of methanol, Chem. Commun., (1968) 265-\&.

[35] R.G. Cooks, Metastable ions, Elsevier Scientific Pub. Co., 1973.

[36] C. Lifshitz, M. Shapiro, Sternber.R, Isotope effects on metastable transitions .4. Isotopic methanols, Isr. J. Chem., 7 (1969) 391-\&.

[37] R.G. Cooks, T. Ast, J.H. Beynon, Anomalous metastable peaks, International Journal of Mass Spectrometry and lon Processes, 16 (1975) 348-352.

[38] R.G. Cooks, D.T. Terwilliger, T. Ast, J.H. Beynon, T. Keough, Surface modified mass-spectrometry, Journal of the American Chemical Society, 97 (1975) 1583-1585.

[39] S.A. Miller, H. Luo, S.J. Pachuta, R.G. Cooks, Soft-landing of polyatomic ions at fluorinated selfassembled monolayer surfaces, Science, 275 (1997) 1447-1450.

[40] A. Bottcher, P. Weis, S.S. Jester, D. Loffler, A. Bihlmeier, W. Klopper, M.M. Kappes, Solid $\mathrm{C}_{58}$ films, Physical Chemistry Chemical Physics, 7 (2005) 2816-2820.

[41] Z. Ouyang, Z. Takats, T.A. Blake, B. Gologan, A.J. Guymon, J.M. Wiseman, J.C. Oliver, V.J. Davisson, R.G. Cooks, Preparing protein microarrays by soft-landing of mass-selected ions, Science, 301 (2003) 1351-1354.

[42] J. Alvarez, R.G. Cooks, S.E. Barlow, D.J. Gaspar, J.H. Futrell, J. Laskin, Preparation and in situ characterization of surfaces using soft landing in a Fourier transform ion cyclotron resonance mass spectrometer, Analytical Chemistry, 77 (2005) 3452-3460.

[43] M. Volny, W.T. Elam, A. Branca, B.D. Ratner, F. Turecek, Preparative soft and reactive landing of multiply charged protein ions on a plasma-treated metal surface, Analytical Chemistry, 77 (2005) 48904896.

[44] H.J. Rader, A. Rouhanipour, A.M. Talarico, V. Palermo, P. Samori, K. Mullen, Processing of giant graphene molecules by soft-landing mass spectrometry, Nature Materials, 5 (2006) 276-280.

[45] R.E. Palmer, S. Pratontep, H.G. Boyen, Nanostructured surfaces from size-selected clusters, Nature Materials, 2 (2003) 443-448.

[46] U. Heiz, F. Vanolli, L. Trento, W.D. Schneider, Chemical reactivity of size-selected supported clusters: An experimental setup, Review of Scientific Instruments, 68 (1997) 1986-1994.

[47] S. Vajda, M.J. Pellin, J.P. Greeley, C.L. Marshall, L.A. Curtiss, G.A. Ballentine, J.W. Elam, S. CatillonMucherie, P.C. Redfern, F. Mehmood, P. Zapol, Subnanometre platinum clusters as highly active and selective catalysts for the oxidative dehydrogenation of propane, Nature Materials, 8 (2009) 213-216. [48] G.E. Johnson, M. Lysonski, J. Laskin, In situ reactivity and TOF-SIMS analysis of surfaces prepared by soft and reactive landing of mass-selected ions, Analytical Chemistry, 82 (2010) 5718-5727.

[49] Z.X. Nie, G.T. Li, M.P. Goodwin, L. Gao, J. Cyriac, R.G. Cooks, In Situ SIMS Analysis and Reactions of Surfaces Prepared by Soft Landing of Mass-Selected Cations and Anions Using an Ion Trap Mass Spectrometer, Journal of the American Society for Mass Spectrometry, 20 (2009) 949-956.

[50] J. Cyriac, M. Wleklinski, G.T. Li, L. Gao, R.G. Cooks, In situ Raman spectroscopy of surfaces modified by ion soft landing, Analyst, 137 (2012) 1363-1369.

[51] M. Volny, A. Sengupta, C.B. Wilson, B.D. Swanson, E.J. Davis, F. Turecek, Surface-enhanced Raman spectroscopy of soft-landed polyatomic ions and molecules, Analytical Chemistry, 79 (2007) 4543-4551.

[52] Q.C. Hu, P. Wang, P.L. Gassman, J. Laskin, In situ studies of soft- and reactive landing of massselected ions using infrared reflection absorption spectroscopy, Analytical Chemistry, 81 (2009) 73027308.

[53] S. Nagaoka, T. Matsumoto, K. Ikemoto, M. Mitsui, A. Nakajima, Soft-landing isolation of multidecker $\mathrm{V}$-2(benzene)(3) complexes in an organic monolayer matrix: An infrared spectroscopy and thermal desorption study, Journal of the American Chemical Society, 129 (2007) 1528-+. 
[54] J.P. Cowin, A.A. Tsekouras, M.J. Iedema, K. Wu, G.B. Ellison, Immobility of protons in ice from 30 to 190 K, Nature, 398 (1999) 405-407.

[55] Z.T. Deng, N. Thontasen, N. Malinowski, G. Rinke, L. Harnau, S. Rauschenbach, K. Kern, A Close Look at Proteins: Submolecular Resolution of Two- and Three-Dimensionally Folded Cytochrome c at Surfaces, Nano Letters, 12 (2012) 2452-2458.

[56] N. Hauptmann, K. Scheil, T.G. Gopakumar, F.L. Otte, C. Schütt, R. Herges, R. Berndt, Surface Control of Alkyl Chain Conformations and 2D Chiral Amplification, Journal of the American Chemical Society, 135 (2013) 8814-8817.

[57] N. Bajales, S. Schmaus, T. Miyamashi, W. Wulfhekel, J. Wilhelm, M. Walz, M. Stendel, A. Bagrets, F. Evers, S. Ulas, B. Kern, A. Bottcher, M.M. Kappes, $\mathrm{C}_{58}$ on $\mathrm{Au}(111)$ : A scanning tunneling microscopy study, Journal of Chemical Physics, 138 (2013) 104703.

[58] S. Ulas, D. Loffler, P. Weis, A. Bottcher, M.M. Kappes, Desorption of $C_{60}$ upon thermal decomposition of cesium $C_{58}$ fullerides, Journal of Chemical Physics, 136 (2012) 114708.

[59] G.E. Johnson, C. Wang, T. Priest, J. Laskin, Monodisperse $\mathrm{Au}_{11}$ clusters prepared by soft landing of mass selected ions, Analytical Chemistry, 83 (2011) 8069-8072.

[60] J.L.P. Benesch, B.T. Ruotolo, D.A. Simmons, N.P. Barrera, N. Morgner, L. Wang, H.R. Saibil, C.V. Robinson, Separating and visualising protein assemblies by means of preparative mass spectrometry and microscopy, Journal of Structural Biology, 172 (2010) 161-168.

[61] M.E. Bier, J.W. Amy, R.G. Cooks, J.E.P. Syka, P. Ceja, G. Stafford, A tandem quadrupole massspectrometer for the study of surface-induced dissociation, International Journal of Mass Spectrometry and Ion Processes, 77 (1987) 31-47.

[62] V.H. Wysocki, J.M. Ding, J.L. Jones, J.H. Callahan, F.L. King, Surface-induced dissociation in tandem quadrupole mass spectrometers - a comparison of 3 designs, Journal of the American Society for Mass Spectrometry, 3 (1992) 27-32.

[63] Z. Ouyang, V. Grill, J. Alvarez, C.H. Doerge, L. Gianelli, P. Thomas, H.W. Rohrs, R.G. Cooks, A multiquadrupole tandem mass spectrometer for the study of ion/surface collision processes, Review of Scientific Instruments, 73 (2002) 2375-2391.

[64] M.E. Bier, J.C. Schwartz, K.L. Schey, R.G. Cooks, Tandem mass-spectrometry using an in-line ion surface collision device, International Journal of Mass Spectrometry and Ion Processes, 103 (1990) 1-19. [65] A.S. Galhena, S. Dagan, C.M. Jones, R.L. Beardsley, V.N. Wysocki, Surface-induced dissociation of peptides and protein complexes in a quadrupole/Time-of-Flight mass spectrometer, Analytical Chemistry, 80 (2008) 1425-1436.

[66] K.L. Schey, D.A. Durkin, K.R. Thornburg, Design and performance of an in-line surface-induced dissociation device in a 4-sector mass-spectrometer, Journal of the American Society for Mass Spectrometry, 6 (1995) 257-263.

[67] S.A. Lammert, R.G. Cooks, Surface-induced dissociation of molecular-ions in a quadrupole ion trap mass-spectrometer, Journal of the American Society for Mass Spectrometry, 2 (1991) 487-491.

[68] B.E. Winger, H.J. Laue, S.R. Horning, R.K. Julian, S.A. Lammert, D.E. Riederer, R.G. Cooks, Hybrid BEEQ tandem mass-spectrometer for the study of ion surface collision processes, Review of Scientific Instruments, 63 (1992) 5613-5625.

[69] K. Schey, R.G. Cooks, R. Grix, H. Wollnik, A tandem time-of-flight mass-spectrometer for surfaceinduced dissociation, International Journal of Mass Spectrometry and Ion Processes, 77 (1987) 49-61.

[70] L.L. Haney, D.E. Riederer, Delayed extraction for improved resolution of ion/surface collision products by time-of-flight mass spectrometry, Analytica Chimica Acta, 397 (1999) 225-233.

[71] E. Stone, K.J. Gillig, B. Ruotolo, K. Fuhrer, M. Gonin, A. Schultz, D.H. Russell, Surface-induced dissociation on a MALDI-ion mobility-orthogonal time-of-flight mass spectrometer: Sequencing peptides from an "in-solution" protein digest, Analytical Chemistry, 73 (2001) 2233-2238. 
[72] C.M. Gamage, F.M. Fernandez, K. Kuppannan, V.H. Wysocki, Submicrosecond surface-induced dissociation of peptide ions in a MALDI TOF MS, Analytical Chemistry, 76 (2004) 5080-5091.

[73] E.N. Nikolaev, A. Somogyi, D.L. Smith, C.G. Gu, V.H. Wysocki, C.D. Martin, G.L. Samuelson, Implementation of low-energy surface-induced dissociation (eV SID) and high-energy collision-induced dissociation ( $\mathrm{keV} \mathrm{CID}$ ) in a linear sector-TOF hybrid tandem mass spectrometer, International Journal of Mass Spectrometry, 212 (2001) 535-551.

[74] C.F. Ijames, C.L. Wilkins, Surface-induced dissociation by fourier-transform mass-spectrometry, Analytical Chemistry, 62 (1990) 1295-1299.

[75] J. Laskin, E.V. Denisov, A.K. Shukla, S.E. Barlow, J.H. Futrell, Surface-induced dissociation in a Fourier transform ion cyclotron resonance mass spectrometer: Instrument design and evaluation, Analytical Chemistry, 74 (2002) 3255-3261.

[76] R.A. Chorush, D.P. Little, S.C. Beu, T.D. Wood, F.W. McLafferty, Surface-induced dissociation of multiply protonated proteins, Analytical Chemistry, 67 (1995) 1042-1046.

[77] W.Q. Zhong, E.N. Nikolaev, J.H. Futrell, V.H. Wysocki, Tandem Fourier transform mass spectrometry studies of surface-induced dissociation of benzene monomer and dimer ions on a self-assembled fluorinated alkanethiolate monolayer surface, Analytical Chemistry, 69 (1997) 2496-2503.

[78] V.S. Rakov, J.H. Futrell, E.V. Denisov, E.N. Nikolaev, Instrumentation of kinetic energy-resolved surface-induced dissociation in Fourier transform mass spectrometry, European Journal of Mass Spectrometry, 6 (2000) 299-317.

[79] W.J. Sun, J.C. May, D.H. Russell, A novel surface-induced dissociation instrument for ion mobilitytime-of-flight mass spectrometry, International Journal of Mass Spectrometry, 259 (2007) 79-86.

[80] W.J. Sun, J.C. May, K.J. Gillig, D.H. Russell, A dual time-of-flight apparatus for an ion mobilitysurface-induced dissociation-mass spectrometer for high-throughput peptide sequencing, International Journal of Mass Spectrometry, 287 (2009) 39-45.

[81] M.W. Zhou, C.S. Huang, V.H. Wysocki, Surface-Induced Dissociation of Ion Mobility-Separated Noncovalent Complexes in a Quadrupole/Time-of-Flight Mass Spectrometer, Analytical Chemistry, 84 (2012) 6016-6023.

[82] A. Budrevich, B. Tsipinyuk, A. Bekkerman, E. Kolodney, Surface scattering of hyperthermal (10-50 eV) neutral $C_{60}$ : Angular and energy distributions, Journal of Chemical Physics, 106 (1997) 5771-5774.

[83] J. Kubista, Z. Dolejsek, Z. Herman, Energy partitioning in collisions of slow polyatomic ions with surfaces: ethanol molecular ions on stainless steel surfaces, European Mass Spectrometry, 4 (1998) 311319.

[84] R. Worgotter, J. Kubista, J. Zabka, Z. Dolejsek, T.D. Mark, Z. Herman, Surface-induced reactions and decomposition of the benzene molecular ion $\mathrm{C} 6 \mathrm{H6}+$ : Product ion intensities, angular and translational energy distributions, International Journal of Mass Spectrometry, 174 (1998) 53-62.

[85] H.L. de Clercq, A.D. Sen, A.K. Shukla, J.H. Futrell, Inelastic ion-surface collisions: scattering and dissociation of low energy benzene molecular cations, International Journal of Mass Spectrometry, 212 (2001) 491-504.

[86] A.K. Shukla, J.H. Futrell, A beam scattering instrument for the dynamics studies of surface-induced dissociation processes, Review of Scientific Instruments, 74 (2003) 168-175.

[87] B.E. Winger, R.K. Julian, R.G. Cooks, C.E.D. Chidsey, Surface-reactions and surface-induced dissociation of polyatomic ions at self-assembled organic monolayer surfaces, Journal of the American Chemical Society, 113 (1991) 8967-8969.

[88] V.H. Wysocki, J.L. Jones, J.M. Ding, Polyatomic ion/surface collisions at self-assembled monolayers films, Journal of the American Chemical Society, 113 (1991) 8969-8970.

[89] J. Laskin, J.H. Futrell, Energy transfer in collisions of peptide ions with surfaces, Journal of Chemical Physics, 119 (2003) 3413-3420. 
[90] U. Heiz, E.L. Bullock, Fundamental aspects of catalysis on supported metal clusters, Journal of Materials Chemistry, 14 (2004) 564-577.

[91] D.-C. Lim, C.-C. Hwang, G. Gantefor, Y.D. Kim, Model catalysts of supported Au nanoparticles and mass-selected clusters, Physical Chemistry Chemical Physics, 12 (2010) 15172-15180.

[92] Z. Herman, Collisions of slow polyatomic ions with surfaces: The scattering method and results, Journal of the American Society for Mass Spectrometry, 14 (2003) 1360-1372.

[93] K.Y. Song, O. Meroueh, W.L. Hase, Dynamics of $\mathrm{Cr}(\mathrm{CO})_{6}{ }^{+}$collisions with hydrogenated surfaces, Journal of Chemical Physics, 118 (2003) 2893-2902.

[94] J. Kubišta, Z. Dolejšek, Z. Herman, Energy partitioning in collisions of slow polyatomic ions with surfaces: ethanol molecular ions on stainless steel surfaces, European Journal of Mass Spectrometry, 4 (1998) 311-319.

[95] R. Wörgötter, J. Kubišta, J. Žabka, Z. Dolejšek, T.D. Märk, Z. Herman, Surface-induced reactions and decomposition of the benzene molecular ion $\mathrm{C}_{6} \mathrm{H}_{6}{ }^{+}$: Product ion intensities, angular and translational energy distributions, International Journal of Mass Spectrometry and Ion Processes, 174 (1998) 53-62.

[96] J. Roithova, J. Zabka, Z. Dolejsek, Z. Herman, Collisions of slow polyatomic ions with surfaces:

Dissociation and chemical reactions of $\mathrm{CD}_{5}{ }^{+}, \mathrm{CD}_{4}{ }^{+}, \mathrm{CD}_{3}{ }^{+}$, and their isotopic variants on room-temperature and heated carbon surfaces, Journal of Physical Chemistry B, 106 (2002) 8293-8301.

[97] A.K. Shukla, J.H. Futrell, Dynamics of hyperthermal energy ion-surface collisions: dissociative and non-dissociative scattering of ethanol cations from a self-assembled monolayer surface of fluorinated alkyl thiol on Au(111), International Journal of Mass Spectrometry, 223 (2003) 783-801.

[98] A.K. Shukla, J.H. Futrell, A.D. Sen, Dynamics of the dissociative and nondissociative scattering of hyperthermal $\mathrm{CS}_{2}{ }^{+}$from a self-assembled fluoroalkyl monolayer surface on gold substrate, Journal of Chemical Physics, 118 (2003) 11217-11225.

[99] J.W. Shen, Y.H. Yim, B.B. Feng, V. Grill, C. Evans, R.G. Cooks, Soft landing of ions onto self-assembled hydrocarbon and fluorocarbon monolayer surfaces, International Journal of Mass Spectrometry, 183 (1999) 423-435.

[100] D.L. Smith, V.H. Wysocki, R. Colorado, O.E. Shmakova, M. Graupe, T.R. Lee, Low-energy ion-surface collisions characterize alkyland fluoroalkyl-terminated self-assembled monolayers on gold, Langmuir, 18 (2002) 3895-3902.

[101] J. Zabka, Z. Dolejsek, Z. Herman, Energy partitioning in collisions of slow polyatomic ions with surfaces: Ethanol molecular ions on surfaces covered by self-assembled monolayers (CF-SAM, CH-SAM, COOH-SAM), Journal of Physical Chemistry A, 106 (2002) 10861-10869.

[102] J. Laskin, E. Denisov, J. Futrell, A comparative study of collision-induced and surface-induced dissociation. 1. Fragmentation of protonated dialanine, Journal of the American Chemical Society, 122 (2000) 9703-9714.

[103] O. Meroueh, W.L. Hase, Dynamics of energy transfer in peptide-surface collisions, Journal of the American Chemical Society, 124 (2002) 1524-1531.

[104] S.B.M. Bosio, W.L. Hase, Simulations of energy transfer in $\mathrm{Cr}(\mathrm{CO})_{6}{ }^{+}$surface-induced dissociation, International Journal of Mass Spectrometry, 174 (1998) 1-9.

[105] O. Meroueh, W.L. Hase, Energy transfer pathways in the collisional activation of peptides, International Journal of Mass Spectrometry, 201 (2000) 233-244.

[106] J.P. Wang, S.O. Meroueh, Y.F. Wang, W.L. Hase, Efficiency of energy transfer in protonated diglycine and dialanine SID - Effects of collision angle, peptide ion size, and intramolecular potential, International Journal of Mass Spectrometry, 230 (2003) 57-64.

[107] A. Rahaman, W.L. Hase, K. Song, J. Wang, O. Meroueh, Chemical Dynamics Simulations of Energy Transfer and Unimolecular Decomposition in Collision-Induced Dissociation (CID) and Surface-Induced Dissociation (SID), in: J. Laskin, C. Lifshitz (Eds.) Principles of Mass Spectrometry Applied to Biomolecules, John Wiley \& Sons., Inc., Hoboken, NJ, 2006. 
[108] G.L. Barnes, W.L. Hase, Energy Transfer, Unfolding, and Fragmentation Dynamics in Collisions of NProtonated Octaglycine with an H-SAM Surface, Journal of the American Chemical Society, 131 (2009) 17185-17193.

[109] L. Yang, O.A. Mazyar, U. Lourderaj, J.P. Wang, M.T. Rodgers, E. Martinez-Nunez, S.V. Addepalli, W.L. Hase, Chemical dynamics simulations of energy transfer in collisions of protonated peptide-ions with a perfluorinated alkylthiol self-assembled monolayer surface, Journal of Physical Chemistry C, 112 (2008) 9377-9386.

[110] J. Laskin, T.H. Bailey, E.V. Denisov, J.H. Futrell, On the relative stability of singly protonated des$\mathrm{Arg}^{1-}$ and des-Arg'-bradykinins, Journal of Physical Chemistry A, 106 (2002) 9832-9836.

[111] J. Laskin, J.H. Futrell, On the efficiency of energy transfer in collisional activation of small peptides, Journal of Chemical Physics, 116 (2002) 4302-4310.

[112] K. Vekey, A. Somogyi, V.H. Wysocki, Internal energy-distribution of benzene molecular-ions in surface-induced dissociation, Journal of Mass Spectrometry, 30 (1995) 212-217.

[113] S.O. Meroueh, Y.F. Wang, W.L. Hase, Direct dynamics Simulations of collision- and surface-induced dissociation of N-protonated glycine. Shattering fragmentation, Journal of Physical Chemistry A, 106 (2002) 9983-9992.

[114] K. Park, B. Deb, K. Song, W.L. Hase, Importance of Shattering Fragmentation in the SurfaceInduced Dissociation of Protonated Octaglycine, Journal of the American Society for Mass Spectrometry, 20 (2009) 939-948.

[115] J. Laskin, J.H. Futrell, Surface-induced dissociation of peptide ions: Kinetics and dynamics, Journal of the American Society for Mass Spectrometry, 14 (2003) 1340-1347.

[116] J. Laskin, K.M. Beck, J.J. Hache, J.H. Futrell, Surface-induced dissociation of ions produced by matrix-assisted laser desorption/ionization in a Fourier transform ion cyclotron resonance mass spectrometer, Analytical Chemistry, 76 (2004) 351-356.

[117] F.M. Fernandez, V.H. Wysocki, J.H. Futrell, J. Laskin, Protein identification via surface-induced dissociation in an FT-ICR mass spectrometer and a patchwork sequencing approach, Journal of the American Society for Mass Spectrometry, 17 (2006) 700-709.

[118] J.L. Jones, A.R. Dongre, A. Somogyi, V.H. Wysocki, Sequence dependence of peptide fragmentation efficiency curves determined by electrospray-ionization surface-induced dissociation massspectrometry, Journal of the American Chemical Society, 116 (1994) 8368-8369.

[119] G. Tsaprailis, H. Nair, A. Somogyi, V.H. Wysocki, W.Q. Zhong, J.H. Futrell, S.G. Summerfield, S.J. Gaskell, Influence of secondary structure on the fragmentation of protonated peptides, Journal of the American Chemical Society, 121 (1999) 5142-5154.

[120] H. Nair, V.H. Wysocki, Are peptides without basic residues protonated primarily at the amino terminus?, International Journal of Mass Spectrometry, 174 (1998) 95-100.

[121] V.H. Wysocki, G. Tsaprailis, L.L. Smith, L.A. Breci, Special feature: Commentary - Mobile and localized protons: a framework for understanding peptide dissociation, Journal of Mass Spectrometry, 35 (2000) 1399-1406.

[122] C.G. Gu, G. Tsaprailis, L. Breci, V.H. Wysocki, Selective gas-phase cleavage at the peptide bond terminal to aspartic acid in fixed-charge derivatives of asp-containing peptides, Analytical Chemistry, 72 (2000) 5804-5813.

[123] G. Tsaprailis, A. Somogyi, E.N. Nikolaev, V.H. Wysocki, Refining the model for selective cleavage at acidic residues in arginine-containing protonated peptides, International Journal of Mass Spectrometry, 195 (2000) 467-479.

[124] Y.Y. Huang, V.H. Wysocki, D.L. Tabb, J.R. Yates, The influence of histidine on cleavage C-terminal to acidic residues in doubly protonated tryptic peptides, International Journal of Mass Spectrometry, 219 (2002) 233-244. 
[125] J. Laskin, T.H. Bailey, J.H. Futrell, Mechanisms of peptide fragmentation from time- and energyresolved surface-induced dissociation studies: Dissociation of angiotensin analogs, International Journal of Mass Spectrometry, 249 (2006) 462-472.

[126] J.M. Spraggins, J.A. Lloyd, M.V. Johnston, J. Laskin, D.P. Ridge, Fragmentation mechanisms of oxidized peptides elucidated by SID, RRKM modeling, and molecular dynamics, Journal of the American Society for Mass Spectrometry, 20 (2009) 1579-1592.

[127] J. Laskin, Z.B. Yang, T. Song, C. Lam, I.K. Chu, Effect of the basic residue on the energetics, dynamics, and mechanisms of gas-phase fragmentation of protonated peptides, Journal of the American Chemical Society, 132 (2010) 16006-16016.

[128] T.H. Bailey, J. Laskin, J.H. Futrell, Energetics of selective cleavage at acidic residues studied by timeand energy-resolved surface-induced dissociation in FT-ICR MS, International Journal of Mass Spectrometry, 222 (2003) 313-327.

[129] J. Laskin, T.H. Bailey, J.H. Futrell, Fragmentation energetics for angiotensin II and its analogs from time-and energy-resolved surface-induced dissociation studies, International Journal of Mass Spectrometry, 234 (2004) 89-99.

[130] J. Laskin, Energy and entropy effects in the gas phase dissociation of peptides and proteins, in: J. Laskin, C. Lifshitz (Eds.) Principles of Mass Spectrometry Applied to Biomolecules, John Wiley \& Sons., Inc., Hoboken, NJ, 2006.

[131] J. Laskin, Energetics and dynamics of fragmentation of protonated leucine enkephalin from timeand energy-resolved surface-induced dissociation studies, Journal of Physical Chemistry A, 110 (2006) 8554-8562.

[132] J. Laskin, M. Byrd, J. Futrell, Internal energy distributions resulting from sustained off-resonance excitation in ftms. I. Fragmentation of the bromobenzene radical cation, International Journal of Mass Spectrometry, 195 (2000) 285-302.

[133] J. Laskin, J. Futrell, Internal energy distributions resulting from sustained off-resonance excitation in fourier transform ion cyclotron resonance mass spectrometry. li. Fragmentation of the 1bromonaphthalene radical cation, Journal of Physical Chemistry A, 104 (2000) 5484-5494. [134] H. Lioe, J. Laskin, G.E. Reid, R.A.J. O'Hair, Energetics and dynamics of the fragmentation reactions of protonated peptides containing methionine sulfoxide or aspartic acid via energy- and time-resolved surface induced dissociation, Journal of Physical Chemistry A, 111 (2007) 10580-10588.

[135] I.K. Chu, J. Laskin, Review formation of peptide radical ions through dissociative electron transfer in ternary metal-ligand-peptide complexes, European Journal of Mass Spectrometry, 17 (2011) 543-556. [136] J. Laskin, Z. Yang, I.K. Chu, Energetics and dynamics of electron transfer and proton transfer in dissociation of metal'"(salen)-peptide complexes in the gas phase, Journal of the American Chemical Society, 130 (2008) 3218-3230.

[137] J. Laskin, J.H. Futrell, I.K. Chu, Is dissociation of peptide radical cations an ergodic process?, Journal of the American Chemical Society, 129 (2007) 9598-+.

[138] Z.B. Yang, C. Lam, I.K. Chu, J. Laskin, The effect of the secondary structure on dissociation of peptide radical cations: Fragmentation of angiotensin III and its analogues, Journal of Physical Chemistry B, 112 (2008) 12468-12478.

[139] J. Laskin, Z.B. Yang, C. Lam, I.K. Chu, Energy and entropy effects in dissociation of peptide radical anions, International Journal of Mass Spectrometry, 316 (2012) 251-258.

[140] J.C. Jurchen, E.R. Williams, Origin of asymmetric charge partitioning in the dissociation of gasphase protein homodimers, Journal of the American Chemical Society, 125 (2003) 2817-2826.

[141] C.M. Jones, R.L. Beardsley, A.S. Galhena, S. Dagan, G.L. Cheng, V.H. Wysocki, Symmetrical gasphase dissociation of noncovalent protein complexes via surface collisions, Journal of the American Chemical Society, 128 (2006) 15044-15045. 
[142] A.E. Blackwell, E.D. Dodds, V. Bandarian, V.H. Wysocki, Revealing the Quaternary Structure of a Heterogeneous Noncovalent Protein Complex through Surface-Induced Dissociation, Analytical Chemistry, 83 (2011) 2862-2865.

[143] E.D. Dodds, A.E. Blackwell, C.M. Jones, K.L. Holso, D.J. O'Brien, M.H.J. Cordes, V.H. Wysocki, Determinants of Gas-Phase Disassembly Behavior in Homodimeric Protein Complexes with Related Yet Divergent Structures, Analytical Chemistry, 83 (2011) 3881-3889.

[144] M.W. Zhou, S. Dagan, V.H. Wysocki, Protein Subunits Released by Surface Collisions of Noncovalent Complexes: Nativelike Compact Structures Revealed by Ion Mobility Mass Spectrometry, Angewandte Chemie-International Edition, 51 (2012) 4336-4339.

[145] M.W. Zhou, S. Dagan, V.H. Wysocki, Impact of charge state on gas-phase behaviors of noncovalent protein complexes in collision induced dissociation and surface induced dissociation, Analyst, 138 (2013) 1353-1362.

[146] M.W. Zhou, C.M. Jones, V.H. Wysocki, Dissecting the Large Noncovalent Protein Complex GroEL with Surface-Induced Dissociation and Ion Mobility Mass Spectrometry, Analytical Chemistry, 85 (2013) 8262-8267.

[147] A.K. Badu-Tawiah, J. Cyriac, R.G. Cooks, Reactions of Organic lons at Ambient Surfaces in a SolventFree Environment, Journal of the American Society for Mass Spectrometry, 23 (2012) 842-849.

[148] A.K. Badu-Tawiah, C.P. Wu, R.G. Cooks, Ambient lon Soft Landing, Analytical Chemistry, 83 (2011) 2648-2654.

[149] J.W. Shen, C. Evans, N. Wade, R.G. Cooks, lon-ion collisions leading to formation of C-C bonds at surfaces: An interfacial Kolbe reaction, Journal of the American Chemical Society, 121 (1999) 9762-9763. [150] J. Alvarez, J.H. Futrell, J. Laskin, Soft-landing of peptides onto self-assembled monolayer surfaces, Journal of Physical Chemistry A, 110 (2006) 1678-1687.

[151] M.B.J. Wijesundara, Y. Ji, B. Ni, S.B. Sinnott, L. Hanley, Effect of polyatomic ion structure on thinfilm growth: Experiments and molecular dynamics simulations, Journal of Applied Physics, 88 (2000) 5004-5016.

[152] N. Wade, C. Evans, S.C. Jo, R.G. Cooks, Silylation of an OH-terminated self-assembled monolayer surface through low-energy collisions of ions: a novel route to synthesis and patterning of surfaces, Journal of Mass Spectrometry, 37 (2002) 591-602.

[153] N. Wade, B. Gologan, A. Vincze, R.G. Cooks, D.M. Sullivan, M.L. Bruening, Esterification and ether formation at a hydroxyl-terminated self-assembled monolayer surface using low-energy collisions of polyatomic cations, Langmuir, 18 (2002) 4799-4808.

[154] P. Wang, O. Hadjar, J. Laskin, Covalent immobilization of peptides on self-assembled monolayer surfaces using soft-landing of mass-selected ions, Journal of the American Chemical Society, 129 (2007) 8682-8683.

[155] P. Wang, O. Hadjar, P.L. Gassman, J. Laskin, Reactive landing of peptide ions on self-assembled monolayer surfaces: an alternative approach for covalent immobilization of peptides on surfaces, Physical Chemistry Chemical Physics, 10 (2008) 1512-1522.

[156] Q.C. Hu, J. Laskin, Reactive landing of dendrimer ions onto activated self-assembled monolayer surfaces, Journal of Physical Chemistry C, (2014).

[157] S. Nagaoka, K. Ikemoto, K. Horiuchi, A. Nakajima, Soft- and Reactive-Landing of Cr(aniline) Sandwich Complexes onto Self-Assembled Monolayers: Separation between Functional and Binding Sites, Journal of the American Chemical Society, 133 (2011) 18719-18727.

[158] M. Volny, W.T. Elam, B.D. Ratner, F. Turecek, Preparative soft and reactive landing of gas-phase ions on plasma-treated metal surfaces, Analytical Chemistry, 77 (2005) 4846-4853.

[159] G.E. Johnson, J. Laskin, Preparation of Surface Organometallic Catalysts by Gas-Phase Ligand Stripping and Reactive Landing of Mass-Selected lons, Chemistry - A European Journal, 16 (2010) 1443314438. 
[160] M. Mitsui, S. Nagaoka, T. Matsumoto, A. Nakajima, Soft-landing isolation of vanadium-benzene sandwich clusters on a room-temperature substrate using n-alkanethiolate self-assembled monolayer matrixes, Journal of Physical Chemistry B, 110 (2006) 2968-2971.

[161] S. Nagaoka, K. Ikemoto, K. Horiuchi, A. Nakajima, Soft- and Reactive-Landing of Cr(aniline)(2) Sandwich Complexes onto Self-Assembled Monolayers: Separation between Functional and Binding Sites, Journal of the American Chemical Society, 133 (2011) 18719-18727.

[162] J. Laskin, P. Wang, O. Hadjar, Soft-landing of Co"l'(salen) ${ }^{+}$and MnIII(salen) ${ }^{+}$on self-assembled monolayer surfaces, Journal of Physical Chemistry C, 114 (2010) 5305-5311.

[163] N. Thontasen, G. Levita, N. Malinowski, Z. Deng, S. Rauschenbach, K. Kern, Grafting Crown Ether Alkali Host-Guest Complexes at Surfaces by Electrospray Ion Beam Deposition, Journal of Physical Chemistry C, 114 (2010) 17768-17772.

[164] L. Hanley, H.J. Lim, D.G. Schultz, S.B. Wainhaus, P. deSainteClaire, W.L. Hase, Surface energy transfer by low energy polyatomic ion collisions, Nuclear Instruments \& Methods in Physics Research Section B-Beam Interactions with Materials and Atoms, 125 (1997) 218-222.

[165] S.C. Nanita, Z. Takats, R.G. Cooks, S. Myung, D.E. Clemmer, Chiral enrichment of serine via formation, dissociation, and soft-landing of octameric cluster ions, Journal of the American Society for Mass Spectrometry, 15 (2004) 1360-1365.

[166] B. Wang, B. Yoon, M. Konig, Y. Fukamori, F. Esch, U. Heiz, U. Landman, Size-Selected Monodisperse Nanoclusters on Supported Graphene: Bonding, Isomerism, and Mobility, Nano Letters, 12 (2012) 59075912.

[167] B. Yoon, H. Hakkinen, U. Landman, A.S. Worz, J.M. Antonietti, S. Abbet, K. Judai, U. Heiz, Charging effects on bonding and catalyzed oxidation of $\mathrm{CO}$ on $\mathrm{Au}_{8}$ clusters on MgO, Science, 307 (2005) 403-407. [168] G. Kwon, G.A. Ferguson, C.J. Heard, E.C. Tyo, C.R. Yin, J. DeBartolo, S. Seifert, R.E. Winans, A.J. Kropf, J. Greeley, R.L. Johnston, L.A. Curtiss, M.J. Pellin, S. Vajda, Size-Dependent Subnanometer Pd Cluster $\left(\mathrm{Pd}_{4}, \mathrm{Pd}_{6}\right.$, and $\left.\mathrm{Pd}_{17}\right)$ Water Oxidation Electrocatalysis, Acs Nano, 7 (2013) 5808-5817.

[169] Y. Lei, F. Mehmood, S. Lee, J. Greeley, B. Lee, S. Seifert, R.E. Winans, J.W. Elam, R.J. Meyer, P.C. Redfern, D. Teschner, R. Schlogl, M.J. Pellin, L.A. Curtiss, S. Vajda, Increased Silver Activity for Direct Propylene Epoxidation via Subnanometer Size Effects, Science, 328 (2010) 224-228.

[170] B. Gologan, Z. Takats, J. Alvarez, J.M. Wiseman, N. Talaty, Z. Ouyang, R.G. Cooks, lon soft-landing into liquids: Protein identification, separation, and purification with retention of biological activity, Journal of the American Society for Mass Spectrometry, 15 (2004) 1874-1884.

[171] P. Wang, J. Laskin, Helical peptide arrays on self-assembled monolayer surfaces through soft and reactive landing of mass-selected ions, Angewandte Chemie-International Edition, 47 (2008) 6678-6680. [172] B.B. Feng, D.S. Wunschel, C.D. Masselon, L. Pasa-Tolic, R.D. Smith, Retrieval of DNA using softlanding after mass analysis by ESI-FTICR for enzymatic manipulation, Journal of the American Chemical Society, 121 (1999) 8961-8962.

[173] G. Siuzdak, B. Bothner, M. Yeager, C. Brugidou, C.M. Fauquet, K. Hoey, C.M. Chang, Mass spectrometry and viral analysis, Chemistry \& Biology, 3 (1996) 45-48.

[174] D. Loffler, S.S. Jester, P. Weis, A. Bottcher, M.M. Kappes, $C_{n}$ films ( $n=50,52,54,56$, and 58) on graphite: Cage size dependent electronic properties, Journal of Chemical Physics, 124 (2006) 054705. [175] D. Loffler, S. Ulas, S.S. Jester, P. Weis, A. Bottcher, M.M. Kappes, Properties of non-IPR fullerene films versus size of the building blocks, Physical Chemistry Chemical Physics, 12 (2010) 10671-10684.

[176] S. Ulas, D. Strelnikov, P. Weis, A. Bottcher, M.M. Kappes, Incorporating $C_{2}$ into $C_{60}$ films, Journal of Chemical Physics, 136 (2012) 014701.

[177] G.R. Blacken, M. Volny, T. Vaisar, M. Sadılek, F. Turecek, In Situ Enrichment of Phosphopeptides on MALDI Plates Functionalized by Reactive Landing of Zirconium(IV)-n-Propoxide Ions, Analytical Chemistry, 79 (2007) 5449-5456. 
[178] W. Hoffmann, G. Verbeck, Toward a Reusable Surface-Enhanced Raman Spectroscopy (SERS) Substrate by Soft-Landing Ion Mobility, Appl. Spectrosc., 67 (2013) 656-660.

[179] A.A. Tsekouras, M.J. ledema, J.P. Cowin, Soft-landed ion diffusion studies on vapor-deposited hydrocarbon films, Journal of Chemical Physics, 111 (1999) 2222-2234.

[180] W.P. Peng, G.E. Johnson, I.C. Fortmeyer, P. Wang, O. Hadjar, R.G. Cooks, J. Laskin, Redox chemistry in thin layers of organometallic complexes prepared using ion soft landing, Physical Chemistry Chemical Physics, 13 (2011) 267-275.

[181] N. Hauptmann, C. Hamann, H. Tang, R. Berndt, Switching and charging of a ruthenium dye on $\mathrm{Ag}(111)$, Physical Chemistry Chemical Physics, 15 (2013) 10326-10330.

[182] Q.C. Hu, P. Wang, J. Laskin, Effect of the surface on the secondary structure of soft landed peptide ions, Physical Chemistry Chemical Physics, 12 (2010) 12802-12810.

[183] S. Kahle, Z.T. Deng, N. Malinowski, C. Tonnoir, A. Forment-Aliaga, N. Thontasen, G. Rinke, D. Le, V. Turkowski, T.S. Rahman, S. Rauschenbach, M. Ternes, K. Kern, The Quantum Magnetism of Individual Manganese-12-Acetate Molecular Magnets Anchored at Surfaces, Nano Letters, 12 (2012) 518-521. [184] O. Hadjar, J.H. Futrell, J. Laskin, First observation of charge reduction and desorption kinetics of multiply protonated peptides soft landed onto self-assembled monolayer surfaces, Journal of Physical Chemistry C, 111 (2007) 18220-18225.

[185] G.L. Barnes, K. Young, L. Yang, W.L. Hase, Fragmentation and reactivity in collisions of protonated diglycine with chemically modified perfluorinated alkylthiolate-self-assembled monolayer surfaces, Journal of Chemical Physics, 134 (2011) 094106.

[186] J. Laskin, P. Wang, O. Hadjar, J.H. Futrell, J. Alvarez, Z.G. Cooks, Charge retention by peptide ions soft-landed onto self-assembled monolayer surfaces, International Journal of Mass Spectrometry, 265 (2007) 237-243.

[187] G.E. Johnson, T. Priest, J. Laskin, Charge retention by gold clusters on surfaces prepared using soft landing of mass selected ions, ACS Nano, 6 (2012) 573-582.

[188] G.E. Johnson, T. Priest, J. Laskin, Coverage-dependent charge reduction of cationic gold clusters on surfaces prepared using soft landing of mass-selected ions, Journal of Physical Chemistry C, 116 (2012) 24977-24986. 


\section{$0-150 \mathrm{eV}$}

Soft Landing

\section{Charge Transfer}

\section{Reactive Landing}

Surface-Induced

Dissociation

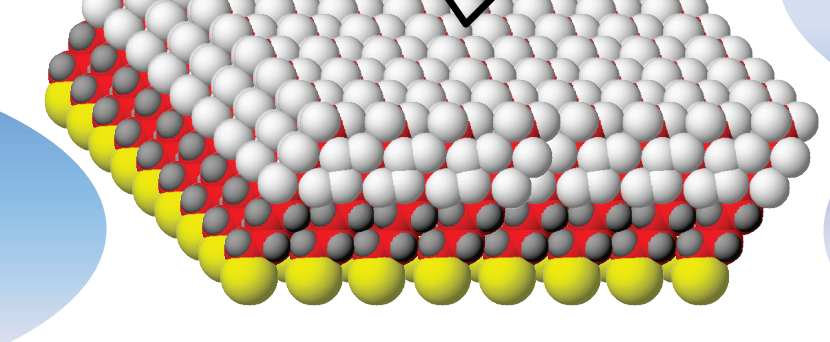

